\title{
The Caddo Archaeological Record in the Saline Creek and County Line Creek Valleys in Cherokee and Smith Counties, Texas
}

Timothy K. Perttula

Heritage Research Center, Stephen F. Austin State University

Bo Nelson

Heritage Research Center, Stephen F. Austin State University

Mark Walters

Heritage Research Center, Stephen F. Austin State University

Follow this and additional works at: https://scholarworks.sfasu.edu/ita

Part of the American Material Culture Commons, Archaeological Anthropology Commons, Environmental Studies Commons, Other American Studies Commons, Other Arts and Humanities Commons, Other History of Art, Architecture, and Archaeology Commons, and the United States History Commons

Tell us how this article helped you.

This Article is brought to you for free and open access by the Center for Regional Heritage Research at SFA ScholarWorks. It has been accepted for inclusion in Index of Texas Archaeology: Open Access Gray Literature from the Lone Star State by an authorized editor of SFA ScholarWorks. For more information, please contact cdsscholarworks@sfasu.edu. 


\section{The Caddo Archaeological Record in the Saline Creek and County Line Creek Valleys in Cherokee and Smith Counties, Texas}

\section{Creative Commons License}

\section{(c) (1) (8)}

This work is licensed under a Creative Commons Attribution-NonCommercial 4.0 International License 


\title{
The Caddo Archaeological Record in the Saline Creek and County Line Creek Valleys in Cherokee and Smith Counties, Texas
}

\author{
Timothy K. Perttula, with contributions by Bo Nelson and Mark Walters
}

\section{Introduction}

Both the Saline and County Line creeks in the upper Neches River basin (Figure 1) were habitats where significant numbers of Caddo peoples lived in ancestral times. As with recent studies of the ancestral Caddo archaeology of the nearby Caddo Creek valley (Perttula and Walters 2016) and the San Pedro Creek valley (Perttula 2016), the purpose of this consideration of the known archaeological record of Caddo settlement in the Saline and County Line creek valleys is to explore the nature of their permanent use during the lengthy native history of Caddo peoples in East Texas between ca. A.D. 900-1838.

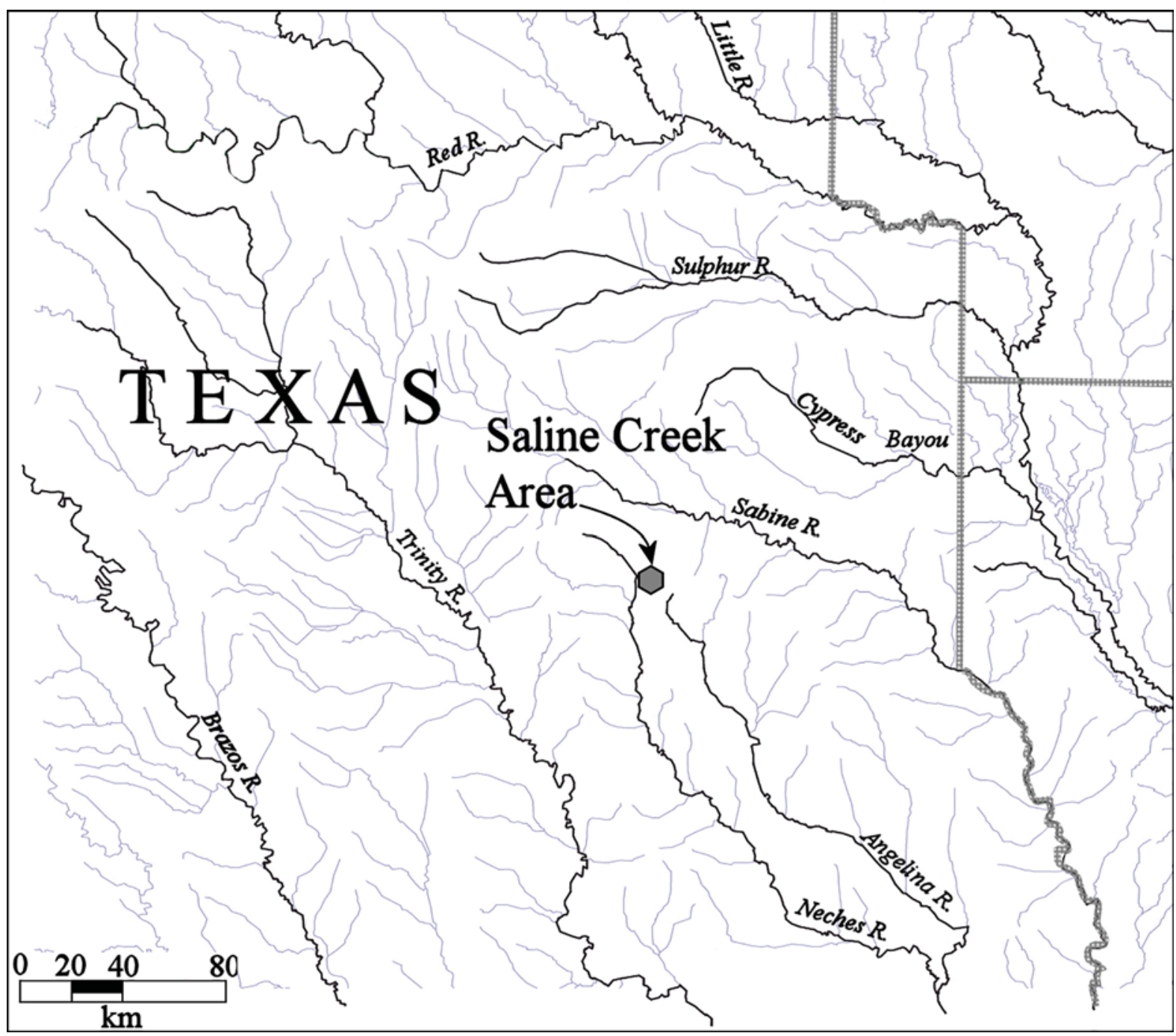

Figure 1. Location of the Saline Creek valley, Cherokee and Smith Counties, in East Texas. 


\section{Environmental and Cultural Setting}

The Saline Creek and County Line creek valleys are in the modern Pineywoods physiographic province, but not far east of the eastern portions of the Post Oak Savannah, in the upper Neches River basin (see Diggs et al. 2006:Figure 2). The Pineywoods cover large parts of East Texas, have mediumtall to tall broadleaf deciduous forests in more mesic habitats, and shortleaf and loblolly pines are common on upland fine sandy loam soils with adequate moisture. In historic and modern times, the Post Oak Savannah is a narrow southwest-northeast trending woodland that marks an ecotone between the more xeric Blackland Prairie to the west and south (Diggs et al. 2006:Figure 2) and the more mesic Pineywoods to the east. The woodlands in the Post Oak Savannah consist of broadleaf deciduous forests, primarily including several species of oak as well as hickory and pecan. Small areas of tall grass prairie may be present in both Pineywoods and Post Oak Savannah communities throughout the region, and this may be particularly the case in more xeric sandy lands. Bottomland communities along the major river and creek drainages contain a diverse hardwood and swamp forest (including cypress, tupelo, and sweet gum), with natural levees and alluvial terraces, point bar deposits, old stream channels, oxbow lakes, and backwater swamps. A less diverse bottomland hardwood community is present along the smaller creeks and their tributaries.

One of the distinctive characteristics of Saline Creek is the large saline prairie on its lower course, just upstream from where the creek flows into the Neches River (Figure 2). The prairie marks the main area of the Brooks salt dome (Skinner 1971:6); the waters of Lake Palestine have now submerged the prairie. The saline prairie was marked by numerous wooded "islands" or natural mounds. The Neches Saline is marked by numerous $19^{\text {th }}$ century salt works, and the earliest of these were apparently in use by 1823 (Skinner 1971:8). Although a few of the recorded sites on the prairie have Caddo archaeological remains (Skinner 1971:22) (see Figure 2), they do not appear to represent Caddo salt making sites of the kinds used by Caddo farmers that are reported along Salt Well Slough in the Red River basin (see Kenmotsu 2005) and at other Caddo salt making sites in Northwest Louisiana (Eubanks 2014).

The great majority of the known ancestral Caddo sites in the Saline Creek and County Line Creek valleys are situated near, but east and upstream from the saline prairie (see Figure 2), in areas with fresh creek water and water supplied by springs that originated in artesian aquifers exposed by the uplifted salt dome. Woldert (1923:186) noted years ago that he had found much Indian (i.e., Caddo) pottery sherds 0.3 miles west of the saline, as well as 1 mile east and 2 miles southeast of the saline. There appear to have been distinct communities in both creek valleys. As will be discussed in more detail below, almost all of the Caddo sites in these two creek valleys were occupied by sedentary Caddo families after ca. A.D. 1400. These families and communities were farmers with a diet more dependent upon domesticated plants-especially maize and beans - than was the case before ca. A.D. 1300 (Perttula 2008:89-94).

\section{Ancestral Caddo Sites in the Saline Creek and County Line Creek Valleys}

\section{William Sherman (41CE30)}

The William Sherman site is one of a number of ancestral Caddo sites situated in upland landforms ca. 0.7-1 km south of County Line Creek (Figure 3). The site had first been found by amateur archaeologists who dug in the years between 1965-1968 a large area in the approximate center of a midden deposit, recovering a large sample of ceramic sherds $(n=593)$, four ceramic spindle whorls, 43 ceramic pipe sherds, 11 Perdiz arrow points, five perforated shell tools, three celt fragments, bone tools (Anderson et al. 1974:Figure 74), and an unknown quantity of animal bone and mussel shell (Anderson et al. 1974:147).

Southern Methodist University (SMU) archaeologists formally recorded the site in 1969 (Anderson 1972:144), and noted that it was located on a low knoll in the uplands, or possibly on an alluvial fan, west of a tributary stream that flows north into County Line Creek (see Figure 3). Midden deposits there 


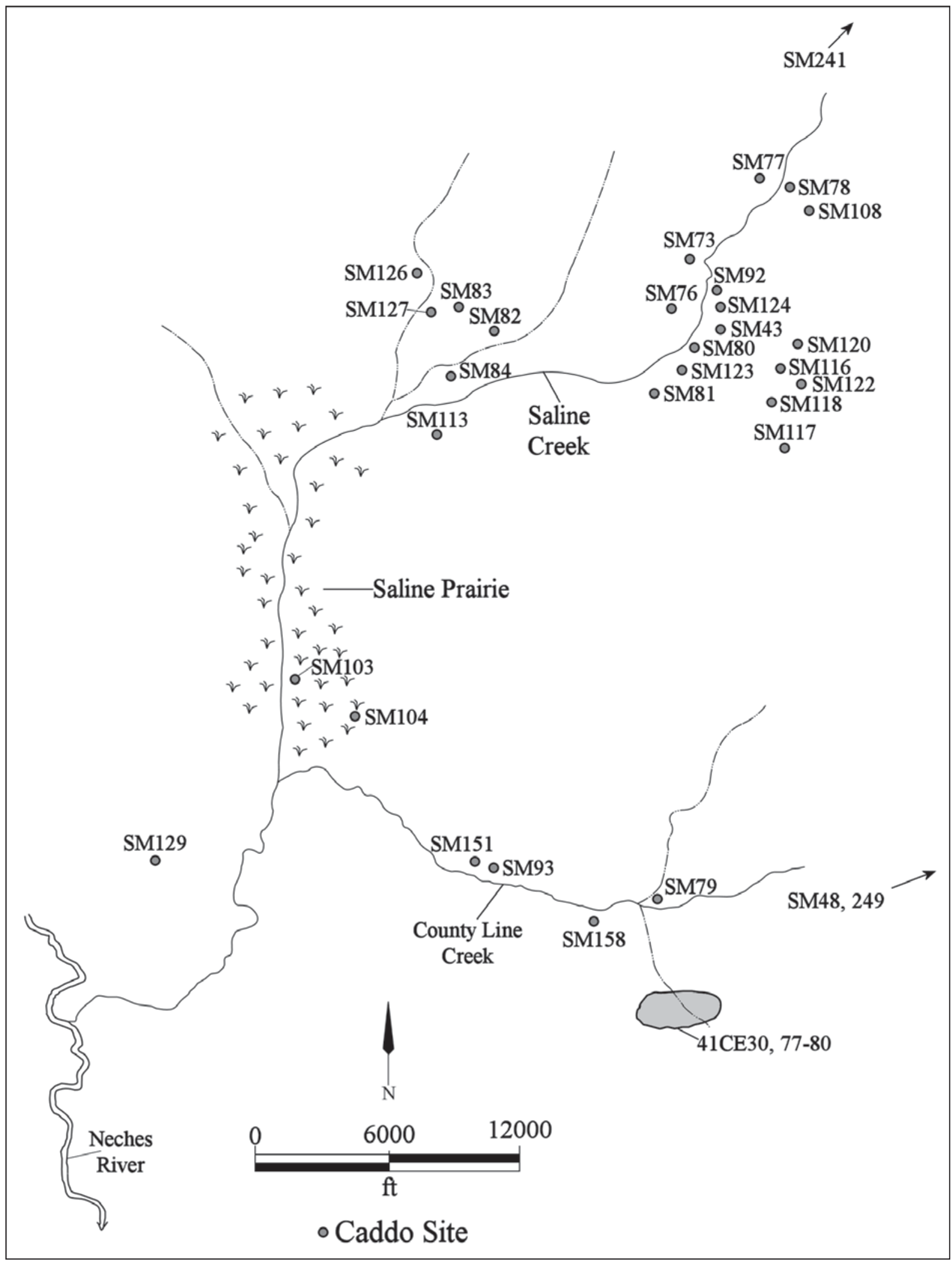

Figure 2. Ancestral Caddo sites in and near the Saline Prairie. 


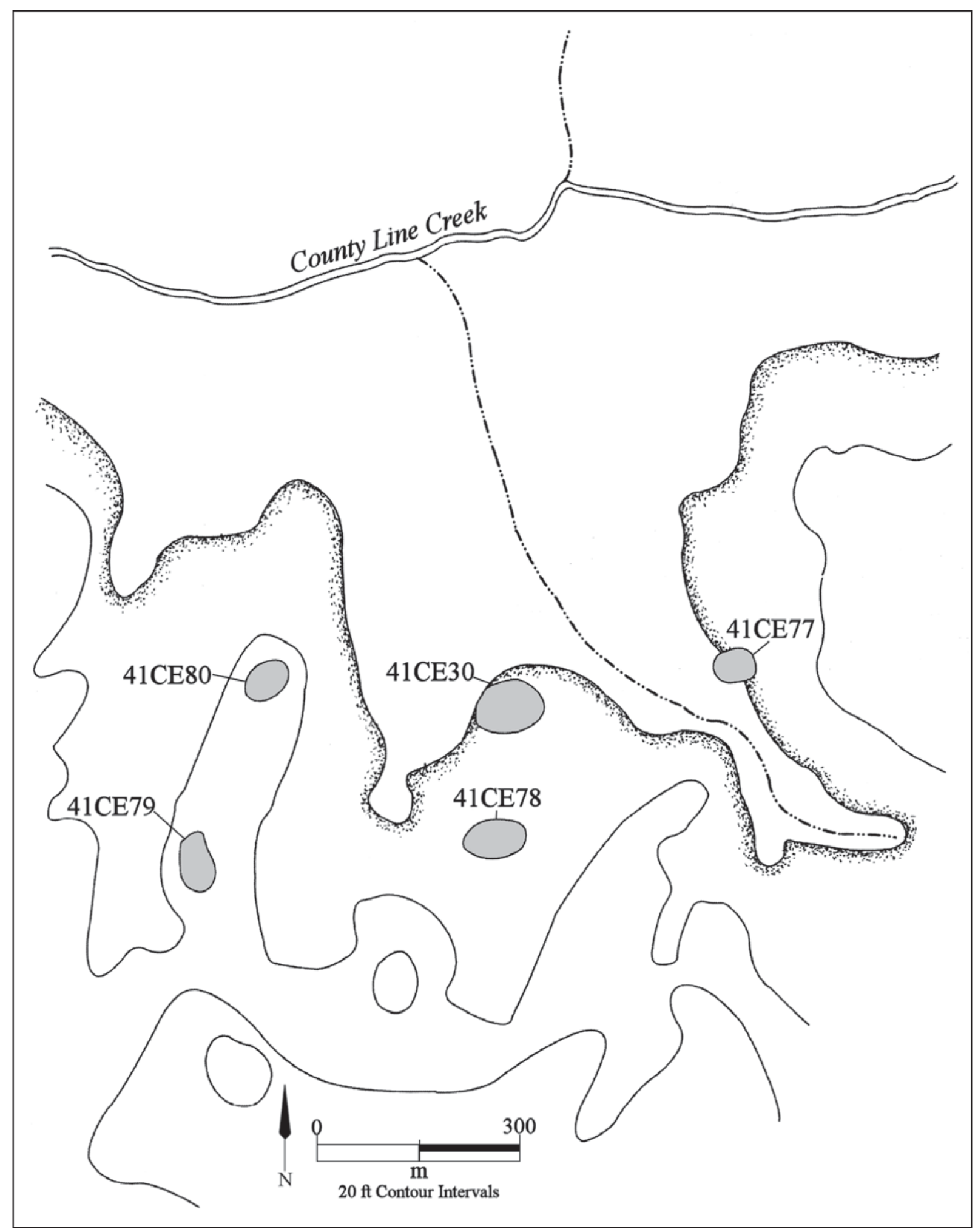

Figure 3. Ancestral Caddo sites in the area of the William Sherman site (41CE30) and County Line Creek (after Anderson et al. 1974:Figure 69). 
had sherds, animal bone, and mussel shells. Next, a 40 x $70 \mathrm{~m}$ area was controlled surface-collected, and 17 units (ca. 2 x $2 \mathrm{~m}$ in size) were excavated within the surface collection grid (Anderson et al. 1974:Figure 70). According to Anderson (1972:186-187), of the 595 sherds found at the William Sherman site during the survey, 65 percent of the sherds had brushed decorative elements. There were also Poynor Engraved sherds ( $n=13)$, La Rue Neck Banded sherds $(n=4)$, sherds with incised decorative elements $(n=17)$, fingernail $(n=18)$ and tool punctated $(n=4)$ sherds, and Killough Pinched sherds $(n=4)$. The plain to decorated sherd ratio in the surface-collected assemblage is 0.30 .

No features were identified in the SMU work, but Anderson et al. (1974) suggest that the excavations were in the area of Caddo midden and possibly two house deposits. Recovered in the SMU work, including the survey, were 909 ceramic sherds, six ceramic pipe sherds, seven pieces of daub, one biface, five arrow points (Perdiz), 125 pieces of lithic debris (mostly of gray or tan chert), and 23.3 grams of mussel shell. Among the ceramic sherds were a number of Poynor Engraved sherds (Figure 4a-e) from fine ware vessels, and a rim sherd from an effigy vessel, as well as sherds from Bullard Brushed, Maydelle Incised, and La Rue Neck Banded utility ware vessels (Figure 5a-f). Anderson et al. (1974:159 and Figure 77h) describe a sherd found at the William Sherman site from a bowl with incised-punctated pedestal legs. Gilmore (1974:196 and Table 68) described the ceramic pipe sherds from the site as coming from elbow pipes with flaring bowls, some of which had the characteristic distal knob on the stem common in Frankston phase elbow pipes. Three of the pipe sherds had incised decorative elements, including triangles, hatched lines, and parallel lines on the distal knob.

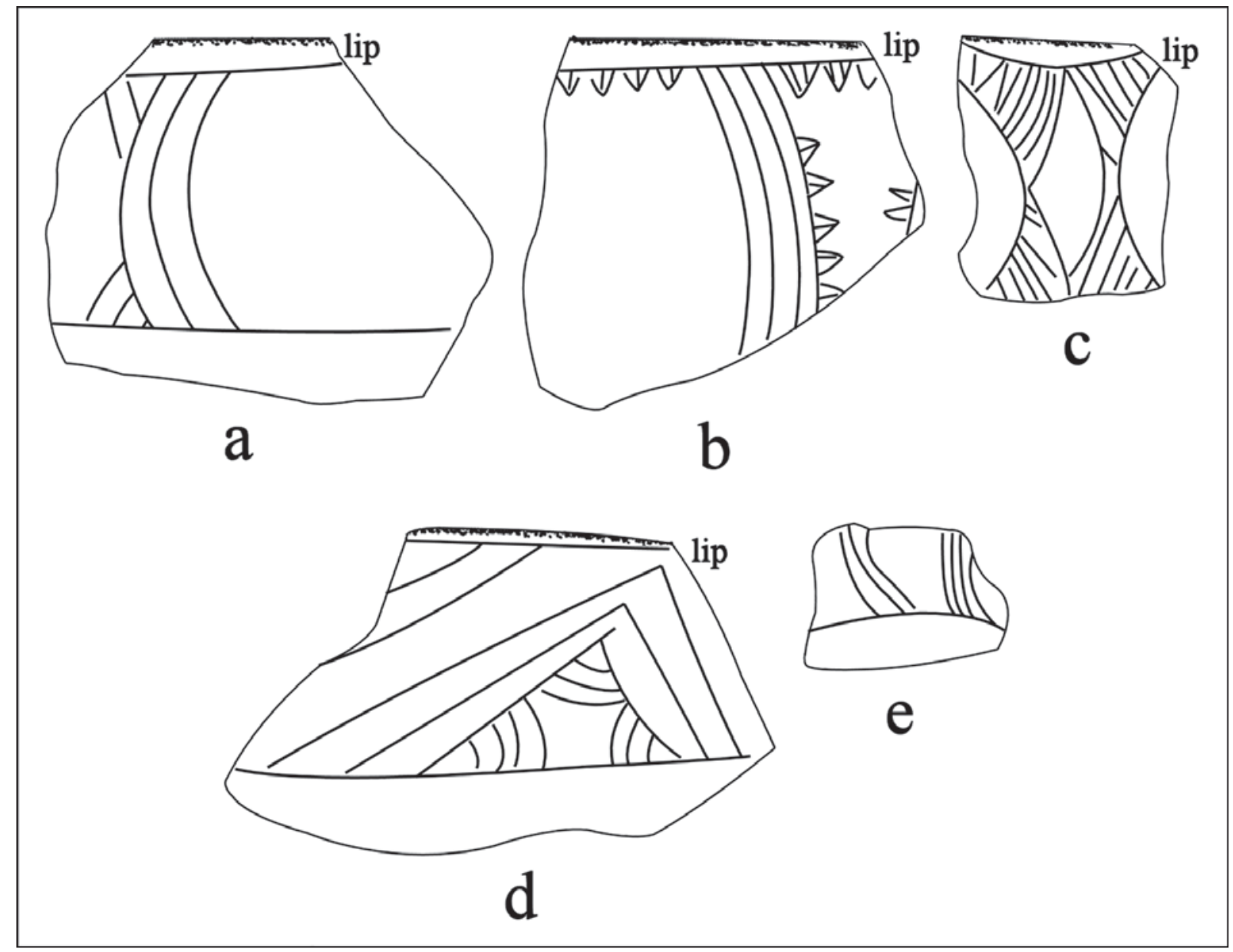

Figure 4. Engraved sherds from the William Sherman site (after Anderson et al. 1974:Figure 76). 


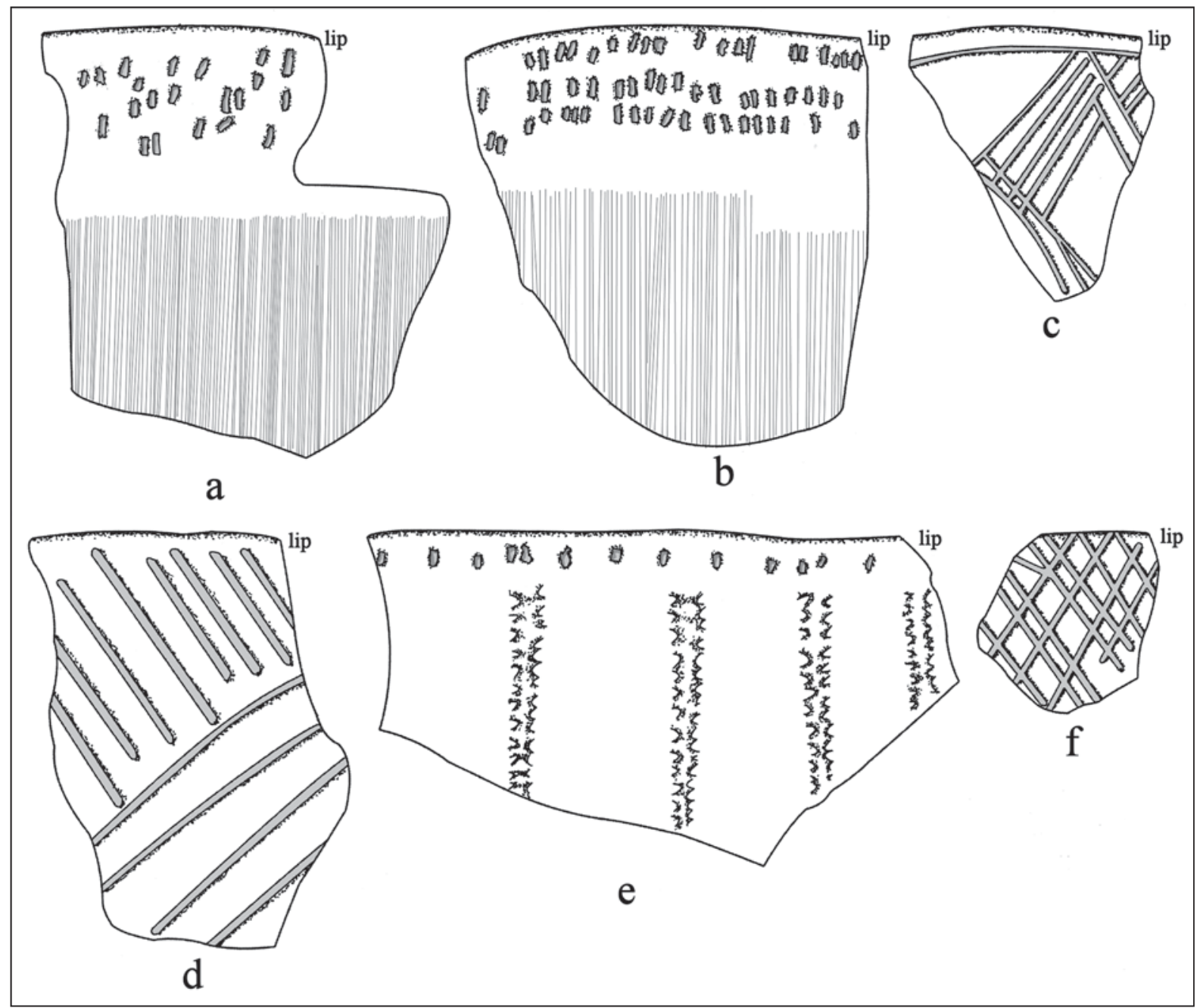

Figure 5. Utility ware sherds from the William Sherman site (after Anderson et al. 1974:Figure 77).

The proportion of brushed sherds in the total decorated sherd assemblage at the William Sherman site -75.8 percent - as well as the percentage of wet paste decorated sherds ( 16.2 percent), a plain to decorated sherd ratio of 0.44 , and a brushed/wet paste sherd ratio of 4.68 , along with the many Poynor Engraved vessels, suggests that the ancestral Caddo occupation took place late in the Frankston phase. This occupation likely occurred between ca. A.D. 1560-1680.

\section{$41 C E 77$}

This ancestral Caddo site of unknown age and character was located on a knoll on an upland slope, near a tributary to County Line Creek (see Figure 3). Ceramic sherds were noted on the surface over a 40 x $30 \mathrm{~m}$ area, but no details are provided in Anderson (1972:Table 13) about the character of the sherds.

\section{$41 C E 78$}

SMU archaeologists identified this site in a cleared and plowed field on an upland landform south of the William Sherman site (see Figure 3), and west of an intermittent tributary to County Line Creek. Ceramic sherds and lithic debris were noted to cover a ca. 40 × $30 \mathrm{~m}$ area of the landform. The small sample of sherds from the site $(n=17)$ were either plain $(n=12)$ or had brushed decorative elements $(n=5)$. 


\section{$41 C E 79$}

41CE79 was located on an upland slope (see Figure 3), and its size was estimated at ca. 40 x $54 \mathrm{~m}$ by the SMU archaeologists. Lithic debris and ceramic sherds were noted on the surface. The ceramic sherds $(n=19)$ were plain $(n=6)$, brushed $(n=9)$, incised $(n=1)$, or engraved $(n=3)$, including one Poynor Engraved sherd; this indicates that 41CE79 likely has a Late Caddo period Frankston phase occupation. The sherds were from vessels tempered with grog $(n=12)$ or grog and bone $(n=3)$.

\section{$41 C E 80$}

This ancestral Caddo site was located at the edge of an upland ridge landform (see Figure 3) that had outcrops of ferruginous sandstone boulders. The site covered an estimated 97 x $41 \mathrm{~m}$ area. The few recovered sherds from 41CE80 were plain $(n=8)$, brushed $(n=1)$, or had incised decorative elements $(n=2)$.

\section{Woldert (41SM43)}

TARL records indicate that this site (also spelled Waldert in the files at TARL), was on the farm of noted historian Dr. Albert Woldert. The site had ancestral Caddo burials, and can be considered a Caddo cemetery, as several ceramic vessels were reported to have been excavated here prior to the late 1930s. It is near Brooks Saline.

\section{Rasco (41SM48)}

The Rasco site is apparently located in the upper reaches of County Line Creek (see Figure 2). Prior to the late 1930s, skeletal remains and ceramic vessels had reportedly been dug up from ancestral Caddo burials on the farm of M. M. Rasco. Although UT archaeologists recorded the site, the site was not investigated by them, and no archaeologists have apparently ever visited the site.

\section{Joe Meyer Estate \#1 (41SM73)}

The Joe Meyer Estate \#1 site (41SM73) is an ancestral Caddo settlement and cemetery on an upland landform west of Saline Creek, a southern-flowing tributary of the Neches River in the upper Neches River basin (see Figure 2). In the spring of 1957 members of the East Texas Archeological Society (ETAS; see Walters 2014), including John Mulligan, Sam Whiteside, Derrell Sanders, and Jowell Proctor, had located the site and commenced excavations. The site had substantial midden deposits as well as Caddo burial features.

W. A. Davis and E. Mott Davis of The University of Texas visited the site in April 1957, took notes on the burial features and associated funerary offerings, and obtained a surface collection of artifacts. The summer of 1957, LeRoy Johnson, Jr. visited the site and obtained a large surface collection of artifacts $(\mathrm{n}=511)$ as part of a broader survey of Blackburn Crossing Reservoir (now Lake Palestine) on the Neches River (Johnson 1961:219-221). In December 1957, E. Mott Davis visited the site again, at which time ETAS members had excavated two test pits (A and B) in the midden deposits.

In June 1969 George Kegley and Dan Witter returned to the site, and made a small surface collection. They also noted that at least 25 Caddo burials (some, if not all, of apparent post-A.D. 1400 age based on the finding of Poynor Engraved vessels) had been excavated in 1966-1967 in another cemetery at the site; one of the main excavators of this cemetery was William "Red" McFarland of Whitehouse, Texas, a well known East Texas digger; this same cemetery may have also been explored by Buddy Jones and ETAS members some years before, where two burials were excavated (Perttula et al. 2013:53-55). Finally, in August 1969 and March 1970, archaeologists from Southern Methodist University (SMU) returned to the Joe Meyer Estate \#1 site as part of a more intensive survey of proposed Lake Palestine (see Anderson 
1972). A large assemblage of ceramic sherds $(n=596)$ was collected from the surface of the site as part of this survey (Anderson 1972:Table 4). About 86 percent of the decorated sherds in this assemblage were from brushed jars (Anderson 1972:Table 13), suggesting the sherds were collected from a Late Caddo occupation area, probably an occupation dating to the $17^{\text {th }}$ century given the very high proportion of brushed sherds in the decorated sherd assemblage (Perttula et al. 2011). The Joe Meyer Estate \#1 site was not one of the sites selected for excavation by SMU before construction of the reservoir (Anderson et al. 1974), likely because the site was not to be inundated by the reservoir flood pool (see Anderson 1972:Figure 1). There have been no professional archaeological investigations at the site since 1970.

The Joe Meyer Estate site covers about 3-5 acres of an upland ridge on the west side of Saline Creek, overlooking the creek floodplain and creek channel (Figure 6); Saline Creek is a southern-flowing tributary of the Neches River. The site is marked by a midden deposit between $60-100 \mathrm{~cm}$ in thickness, with abundant sherds, animal bones, and pieces of mussel shell. In one part of the midden, seven ancestral Caddo burial features dating to the Early Caddo period (ca. A.D. 900-1200) were identified and excavated (Burials 1-6 and Multiple Burial 1). Funerary offerings were present with each of the burial features, and the ETAS work in 1957 had also uncovered a Late Caddo period (ca. A.D. 1400-1650) Poynor Engraved vessel from an undisclosed location within the site. This find may be the first evidence that there was also a Lake Caddo period Frankston phase cemetery on the site, and this cemetery was apparently excavated in the 1960s (see above).

Six of the burial features at the Joe Meyer Estate \#1 site are individual burials (Burials 1-6) placed in a single north-south row in an extended supine position with the head of the deceased facing generally west (Burials 1-5) or northwest (Burial 6) (Figure 7). The area excavated to exposed the burial features was ca. $6 \mathrm{~m}$ (north-south) x $9 \mathrm{~m}$ (east-west) in size. These burials lay in the lowest part of the midden deposits, from ca. 81-102 cm bs. Funerary offerings with the burials included 12 ceramic vessels - between one to four vessels per burial; one of the vessels (unfortunately, which vessel is not known) contained a green clay pigment and mussel shells.

The multiple burial west of Burials 5 and 6 (see Figure 7) had four individuals laid out in an extended supine position, with their heads facing west. The multiple burial was in the upper part of the midden, with a bottom depth of only ca. $61 \mathrm{~cm}$ bs. Based simply on depth of this burial feature and the likelihood that the burial pit encountered and disturbed Burials 5 and 6 (see Figure 7), it is probable that the multiple burial was the latest burial feature in this cemetery. Funerary offerings included three ceramic vessels.

The artifact assemblage from the Joe Meyer Estate \#1 site includes 15 ceramic vessels or portions of vessels from the Early Caddo period burial features, 820 ceramic sherds from midden deposits on the site, one Red River long-stemmed pipe sherd, and two Woodland period dart points.

The 15 ceramic vessels or portions of vessels in the burial features include bottles $(n=4)$, jars $(n=2)$, bowls ( $n=6$ ), and carinated bowls ( $n=3$ ) (Figure 8 and Table 1). Most of the vessels are plain (67 percent), but those that are decorated include a Canton Incised bowl in Burial 4 (Figure 8f), a carinated bowl in Burial 3 with a reworked rim that has alternating series of ovals with excised and cross-hatched engraved zones (Figure 9), a bottle in Burial 5 with short and widely-spaced pinched ridges on its body (Figure 8h), a Hickory Engraved bottle in the Multiple Burial (Figure 81), and a Weches Fingernail Impressed carinated bowl in the Multiple Burial (Figure 8m). 


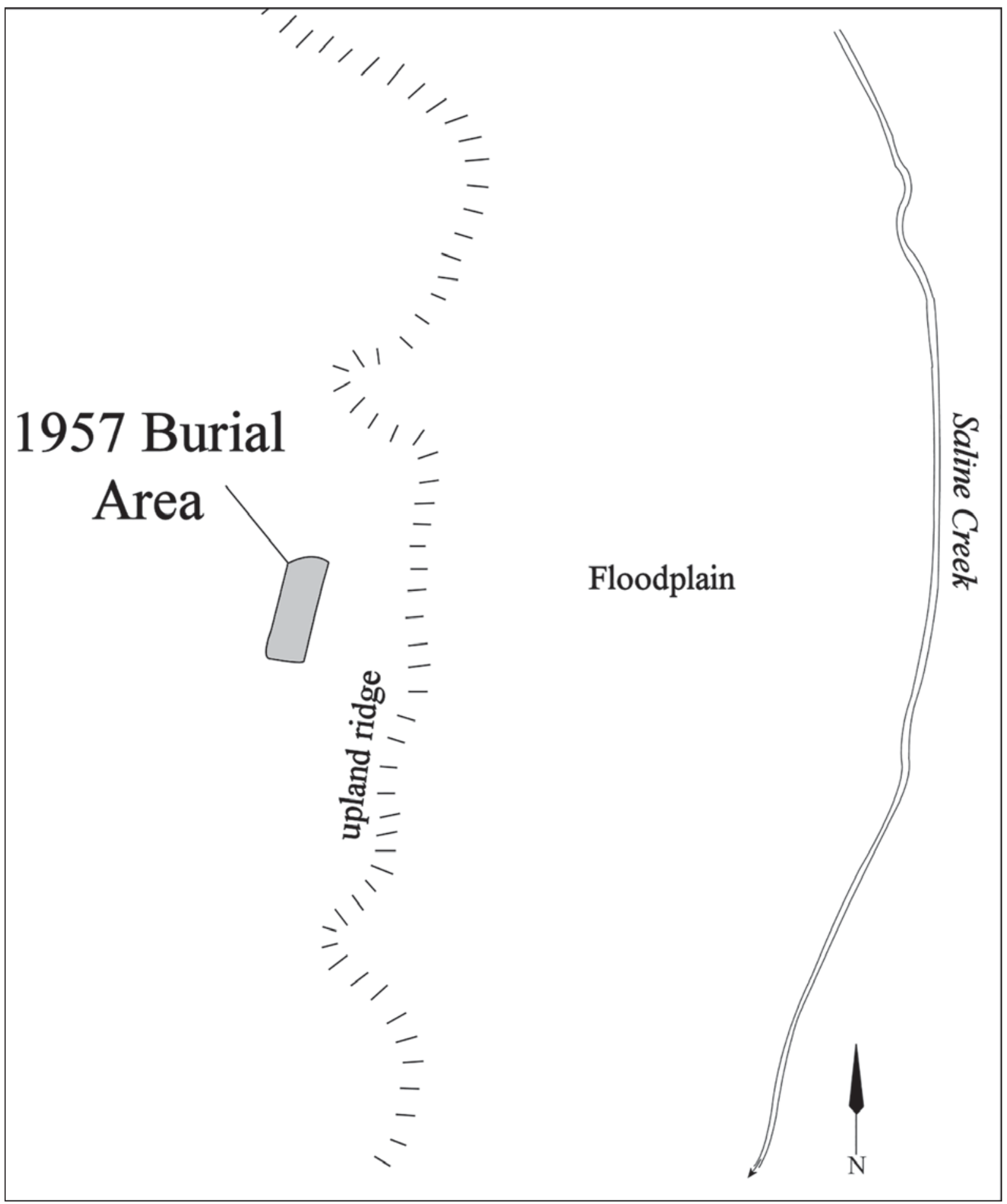

Figure 6. One of the burial areas at the Joe Meyer Estate \#1 site (41SM73) in the Saline Creek valley. 


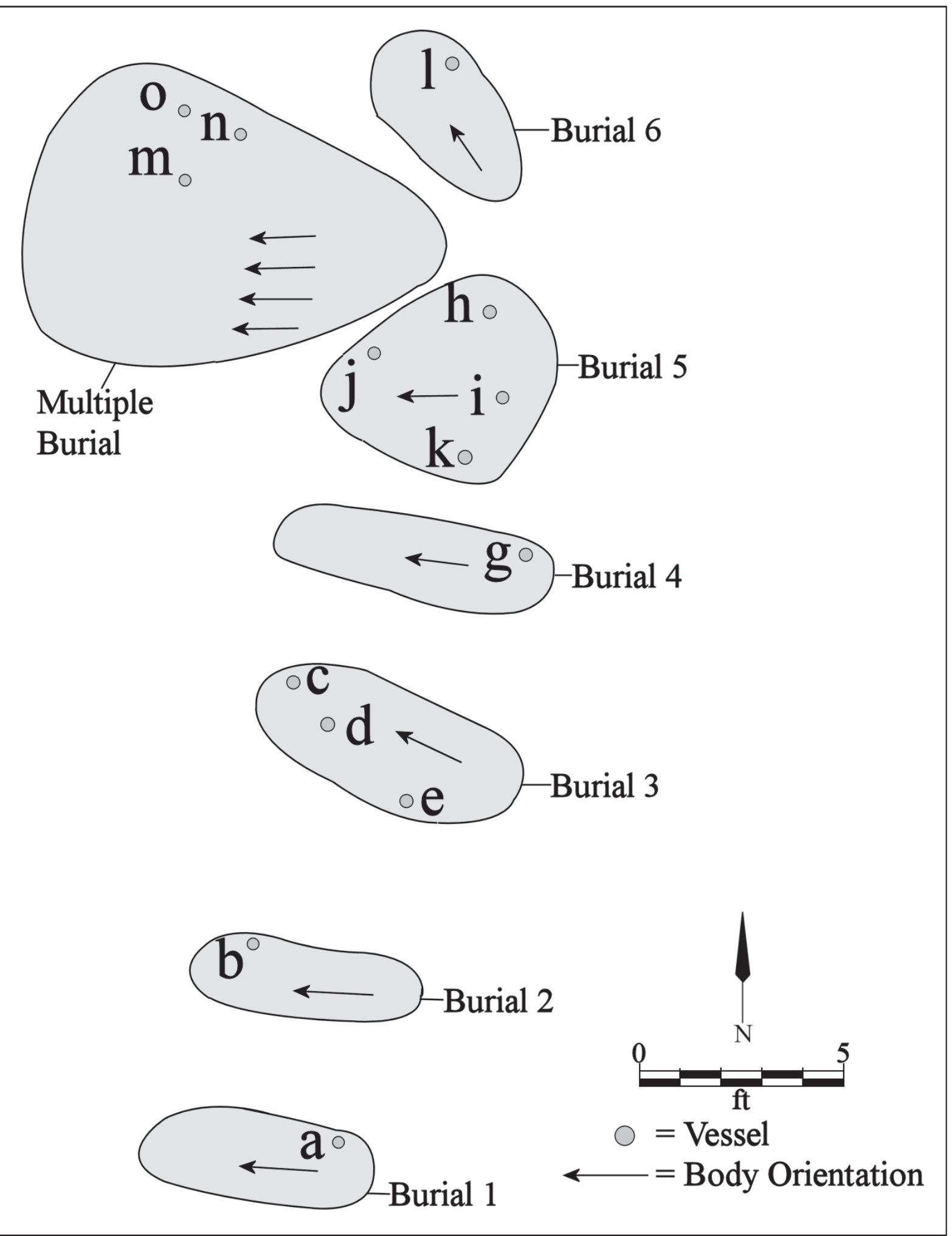

Figure 7. Plan of the cemetery at the Joe Meyer Estate \#1 site (41SM73). 


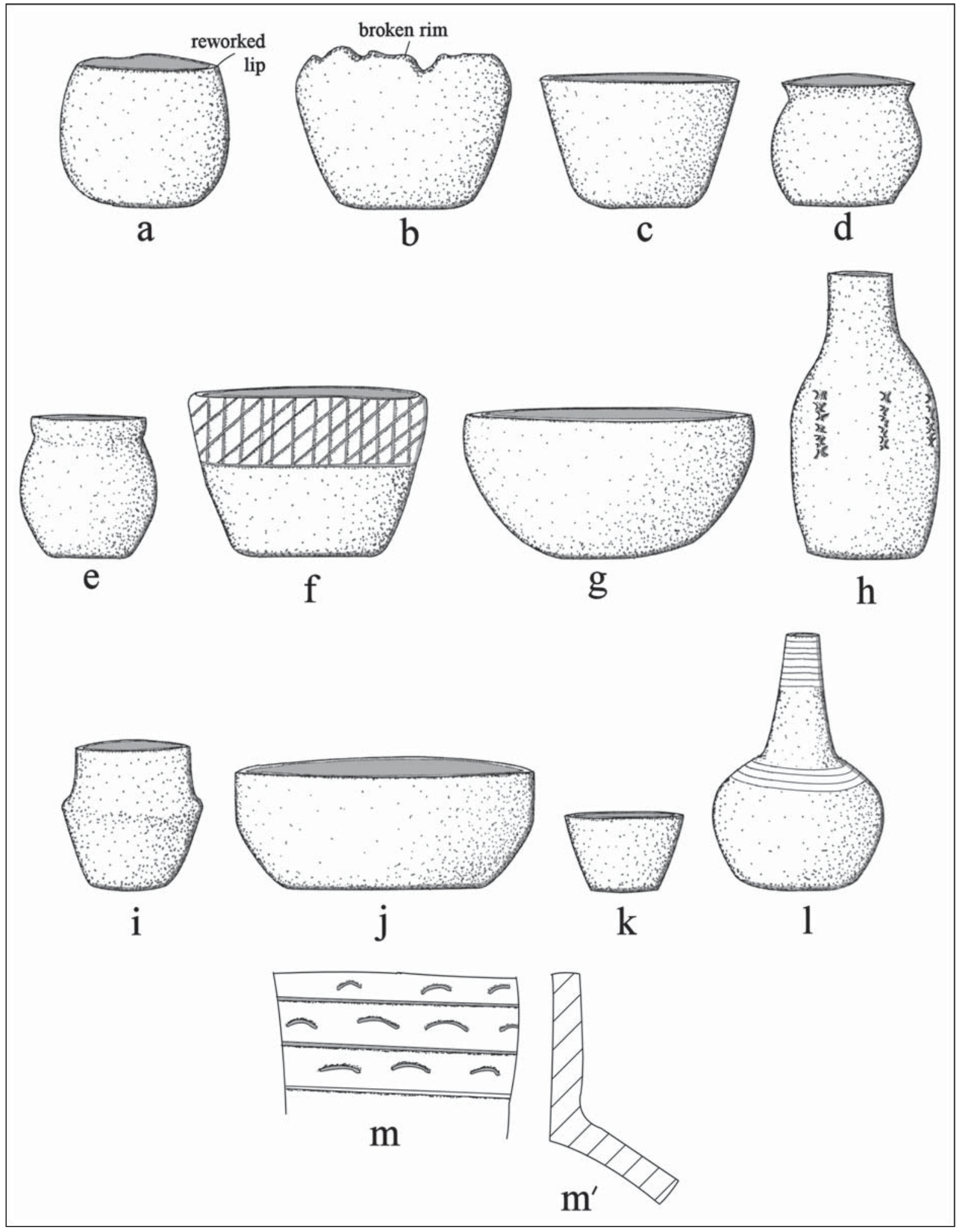

Figure 8. Vessels from Burials 1-6 and Multiple Burial at the Joe Meyer Estate \#1 site: a, Vessel A, Burial 1; b, Vessel B, Burial 2; c, Vessel C, Burial 3; d, Vessel D, Burial 3; e, Vessel F, Burial 3; f, Vessel G, Burial 4; g, Vessel H, Burial 5; h, Vessel I, Burial 5; i, Vessel J, Burial 5; j, Vessel K, Burial 5; k, Vessel L, Burial 6; 1, Vessel M, Multiple Burial; m, Vessel O, Multiple Burial. 
Table 1. Vessel attributes from burials at the Joe Meyer Estate \#1 site.

\begin{tabular}{llllc}
\hline Burial No. & Vessel & Temper & $\begin{array}{l}\text { Height } \\
(\mathrm{cm})\end{array}$ & $\begin{array}{c}\text { Orifice Diameter } \\
(\mathrm{cm})\end{array}$ \\
\hline 1 & $\mathrm{~A}$ & bone & - & $12.0^{*}$ \\
2 & $\mathrm{~B}$ & grog-bone & - & 15.0 \\
3 & $\mathrm{C}$ & bone & 10.0 & 16.0 \\
3 & $\mathrm{D}$ & bone & 10.0 & 10.0 \\
3 & $\mathrm{E}$ & bone & $* *$ & 14.0 \\
3 & $\mathrm{~F}$ & grog & 6.0 & 7.0 \\
4 & $\mathrm{G}$ & - & 7.0 & 10.0 \\
5 & $\mathrm{H}$ & bone & 8.0 & 15.0 \\
5 & $\mathrm{I}$ & bone & 12.0 & 7.0 \\
5 & $\mathrm{~J}$ & grog & 6.0 & 7.0 \\
5 & $\mathrm{~K}$ & bone & 5.0 & 10.0 \\
6 & $\mathrm{~L}$ & grog & 7.0 & 15.0 \\
Multiple & $\mathrm{M}$ & - & 24.0 & 5.0 \\
Multiple & $\mathrm{N}$ & grog-bone & - & - \\
Multiple & $\mathrm{O}$ & & - & - \\
\hline
\end{tabular}

*maximum body diameter

**reworked rim

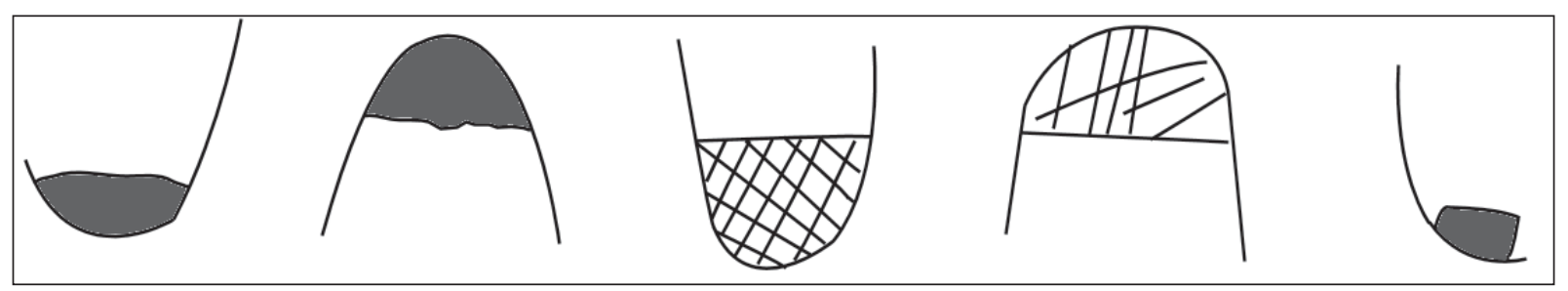

Figure 9. Engraved decorative elements on Vessel E, Burial 3.

With the exception of the Hickory Engraved bottle from the Multiple Burial (see Figure 81), the vessels from the Early Caddo cemetery are small in size, with heights ranging from only $5.0-12.0 \mathrm{~cm}$ and orifice diameters ranging between 7.0-16.0 $\mathrm{cm}$. None of the vessels would have held more than 1 liter of contents. Vessels are tempered with grog $(n=3)$, grog and bone $(n=3)$, and bone $(n=7)$; the use of burned bone as a temper is apparently considerable in the vessels when compared to the vessel sherds from the midden, as Johnson had noted on 1957 inventory forms that grog was the most common temper and that bone temper was rare (see below).

In addition to these vessels from Early Caddo burial contexts, it is known that there were Late Caddo Frankston phase burial features excavated in another cemetery at the Joe Meyer Estate \#1 site. The only ceramic vessel from the Frankston phase burials that can be definitively identified as coming from the site is a grog-tempered Poynor Engraved, var. Cook carinated bowl in the Bernie Ward collection (Perttula et al. 2009:6, 11-12 and Figure 5) (see below).

A sample of 820 ceramic sherds have been collected from the Joe Meyer Estate \#1 site from a series of surface collections by different universities as well as in 10 stratigraphic tests excavated by Sam Whiteside of the ETAS (Table 2). These sherds include plain wares $(n=489,59.6$ percent of the assemblage), utility wares $(\mathrm{m}=314,38.3$ percent), and fine wares $(\mathrm{n}=17,2.1$ percent). The sherds are primarily from vessels tempered with grog (79 percent) or bone (21 percent), based on an examination of 1969 UT and 1969/1970 SMU collections at the Texas Archeological Research Laboratory at The University of Texas at Austin (TARL). 
Table 2. Ceramic sherd assemblage from the Joe Meyer Estate \#1 site.

\begin{tabular}{lllll}
\hline Decorative Method/ & Johnson & UT & SMU & Whiteside \\
Type & $(1961)$ & $(1969)$ & $(1969 /$ & \\
& & & $1970)$ &
\end{tabular}

\begin{tabular}{|c|c|c|c|c|}
\hline \multicolumn{5}{|l|}{ Plain ware } \\
\hline Plain rim & 18 & - & - & - \\
\hline Plain body & 320 & 6 & $37 *$ & $108^{*}$ \\
\hline Subtotal, plain & 338 & 6 & 37 & 108 \\
\hline \multicolumn{5}{|l|}{ Utility ware } \\
\hline Brushed & 39 & 3 & 42 & 22 \\
\hline Brushed-Incised & 4 & - & - & - \\
\hline Brushed-Punctated & - & - & 1 & 1 \\
\hline Subtotal, brushed & 43 & 3 & 43 & 23 \\
\hline Canton Incised & 2 & - & 1 & - \\
\hline Davis Incised & 48 & - & - & 9 \\
\hline Dunkin Incised & 1 & - & - & 3 \\
\hline Incised, Misc. & 9 & 1 & 2 & 14 \\
\hline Subtotal, incised & 60 & 1 & 3 & 26 \\
\hline Incised-Punctated & - & - & - & 1 \\
\hline Fingernail Punctated & 50 & - & - & - \\
\hline Sinner Linear Punctated & 4 & - & - & - \\
\hline Tool Punctated & - & 1 & 3 & - \\
\hline $\begin{array}{l}\text { Weches Fingernail } \\
\text { Impressed }\end{array}$ & 6 & - & - & 4 \\
\hline Punctated, Misc. & - & - & 8 & 35 \\
\hline Subtotal, punctated & 60 & 1 & 11 & 39 \\
\hline \multicolumn{5}{|l|}{ Fine ware } \\
\hline Holly/Hickory Engraved & - & - & - & 3 \\
\hline Holly Fine Engraved & - & - & - & 3 \\
\hline Hickory Engraved & 1 & - & - & - \\
\hline Poynor Engraved & - & - & 1 & 1 \\
\hline Engraved, Misc. & 1 & - & 2 & 2 \\
\hline Subtotal, engraved & 2 & - & 3 & 9 \\
\hline Red-slipped & 1 & - & - & - \\
\hline Trailed & 1 & - & - & 1 \\
\hline Totals & 505 & 11 & 97 & 207 \\
\hline
\end{tabular}

*includes both rim and body sherds

Of the sherds with decorative elements $(\mathrm{n}=331)$, most are from utility ware vessels with punctated (33.5 percent of the decorated sherds), brushed (32.0 percent), and incised ( 27.2 percent) decorations (Figure 10b; see also Table 2). Other utility wares in the assemblage have brushed-incised (1.2 percent), brushed-punctated ( $\mathrm{n}=0.6$ percent, Figure $10 \mathrm{a})$, and incised-punctated ( 0.3 percent) decorative elements. 

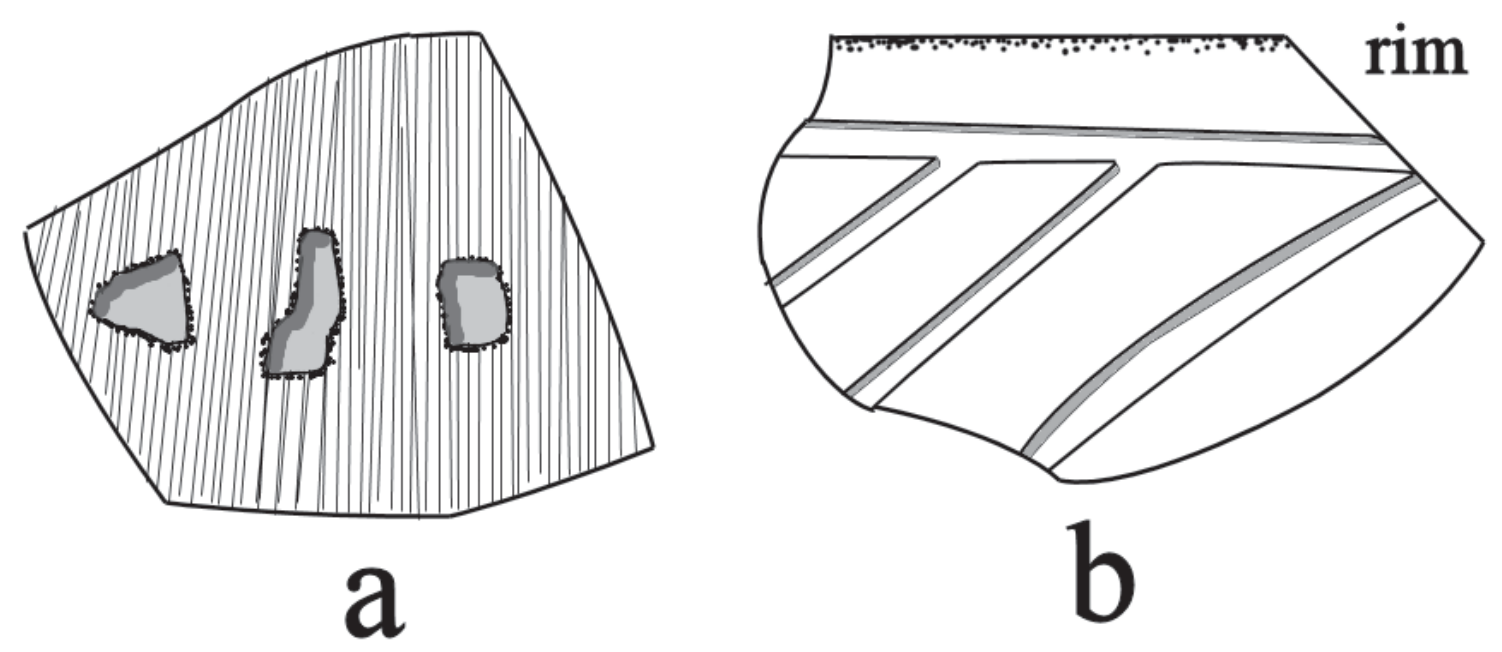

Figure 10. Decorative elements on utility ware sherds: a, brushed-punctated body; b, incised rim.

Fine wares comprise only 5.2 percent of the decorated sherds in the assemblage, primarily sherds with engraved (4.2 percent) designs; the remainder of the fine wares have slipped ( 0.3 percent) and trailed ( 0.6 percent) decorative elements (see Table 2).

Recognized types in the decorated sherds from the Joe Meyer Estate \#1 site include Bullard Brushed, Canton Incised, Davis Incised, Dunkin Incised, Weches Fingernail Impressed, Hickory Engraved, Holly Fine Engraved, and Poynor Engraved (see Table 2). Sherds in John Mulligan's collection included those from Davis Incised, Canton Incised, Crockett Curvilinear Incised, and Holly Fine Engraved vessels. With the exception of the Bullard Brushed and Poynor Engraved sherds, which are apparently from Frankston phase habitation areas, the remainder of the identifiable ceramic types in the sherd assemblage are from a ca. A.D. 900-1200 Early Caddo occupation that was contemporaneous with the known burial features (see Figure 7).

A single pre-A.D. 1400 Red River long-stemmed ceramic pipe stem sherd (see Hoffman 1967) was reported from Strat. Test 4 excavated by Whiteside (TARL inventory sheets). No other details about the pipe stem are available.

There is a small Gary dart point (quartzite) and a gray chalcedony Kent dart point in the collections from the Joe Meyer Estate \#1 site. These dart points indicate that there was some use of the site landform in Woodland period times (ca. 500 B.C. to A.D. 800).

In summary, the Joe Meyer Estate \#1 site is located on an upland ridge overlooking the Saline Creek floodplain, in the upper Neches River basin in East Texas. It was primarily investigated by the East Texas Archeological Society in 1957, but professional archaeologists also visited the site in 1957, 1969, and 1970 as part of large-scale investigations at then proposed Lake Palestine.

While first used by aboriginal peoples sometime during the Woodland period, the principal occupation of the Joe Meyer Estate \#1 site was by ancestral Caddo peoples. The occupation was intensive, as a large and relatively thick midden deposit accumulated on the landform, and it is likely that there are house structural features preserved in the archaeological deposits here. The sherds recovered from the midden deposits are primarily from an Early Caddo period occupation marked by Canton Incised, Davis Incised, Dunkin Incised, and Weches Fingernail Impressed utility ware vessels and Hickory Engraved and Holly Fine Engraved fine ware vessels. There also are Late Caddo period Frankston phase ceramics 
in the assemblage - including Bullard Brushed and Poynor Engraved - that indicate a second ancestral Caddo occupation at the site, one that took place after ca. A.D. 1400.

In one area of the midden was a rare Early Caddo period (ca. A.D. 900-1200) cemetery with single individual burials and one multiple burial with four individuals. Almost all of the known Caddo cemeteries in the upper Neches River basin date to after ca. A.D. 1300-1400 (Perttula et al. 2011). The multiple burial may have been the latest internment in the cemetery based on its shallow depth in the midden and its position relative to the single row of six individual interments. These burials were oriented generally east-west, with the heads of the deceased facing west towards the House of Death in the Sky (see Hatcher 1927:162; Perttula et al. 2011:403-433). The burials were accompanied by ceramic vessels, between one and four vessels per burial, with an average of 2.1 vessels per burial. One vessel in one of the burials contained a green clay pigment mass and mussel shells.

In addition to the Early Caddo period cemetery, there was also a Late Caddo Frankston phase cemetery at the Joe Meyer Estate \#1 site that may have contained 25+ individuals. Unfortunately, very little information is known about this cemetery, and it apparently was excavated by individuals not affiliated with the East Texas Archeological Society. However, this cemetery was likely contemporaneous with a Frankston phase settlement that is indicated by the recovery of Bullard Brushed and Poynor Engraved sherds in the ceramic assemblage from the site's midden. The one documented Frankston phase vessel from the Joe Meyer Estate \#1 site is in the Bernie Ward collection (Perttula et al. 2009:6). Poynor Engraved, var. Cook vessels are present in burials dating to all three sub-phases of the Frankston phase, but are more common in contexts dating between ca. A.D. 1400-1560 (Perttula 2011:Table 6-37).

SITE NAME OR SITE NUMBER: Joe Meyers (41SM73)

VESSEL NO.: BW-1

NON-PLASTICS: grog and hematite

VESSEL FORM: Carinated bowl

RIM AND LIP FORM: inverted rim and rounded lip

CORE COLOR: F (fired in a reducing environment and cooled in the open air)

INTERIOR SURFACE COLOR: yellowish-brown (10YR 5/4)

EXTERIOR SURFACE COLOR: light yellowish-brown (10YR 6/4)

WALL THICKNESS (RIM, BODY, AND BASE IN MM): $9.5 \mathrm{~mm}$, rim

INTERIOR SURFACE TREATMENT: smoothed on the rim

EXTERIOR SURFACE TREATMENT: smoothed on the rim and body

HEIGHT (IN CM): 16.0

ORIFICE DIAMETER (IN CM): 26.3 


\section{DIAMETER AT BOTTOM OF RIM OR NECK (IN CM): 27.3}

\section{BASE DIAMETER (IN CM): 9.5}

\section{ESTIMATED VOLUME (IN LITERS): 3.78 liters}

DECORATION: The engraved panel on the rim has a series of ovals with near-vertical arches between the large ovals; horizontal brushed body (Figure 11).

TYPE: Poynor Engraved, var. Cook

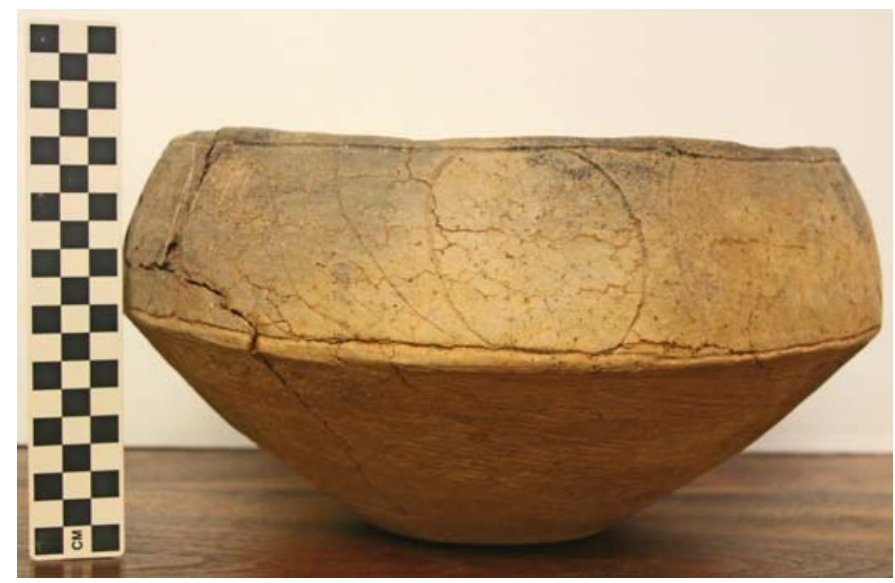

Figure 11. Poynor Engraved, var. Cook carinated bowl from the Joe Meyer Estate \#1 site (41SM73).

\section{$41 S M 76$}

This ancestral Caddo site is located "on a low hill adjacent to the west floodplain of Saline Creek" (Johnson 1961:223), likely a terrace ca. $15 \mathrm{~m}$ west of the creek. The site was cultivated at the time of Johnson's survey, and was estimated to cover about 2 acres; Buddy Calvin Jones had told Johnson of the site. The material culture remains from the site included a Late Archaic Yarbrough point and 192 ceramic sherds from an apparent Late Caddo period Frankston phase occupation. The plain to decorated sherd ratio of the surface collection assemblage is 1.06 , with 99 plain sherds, 62 sherds with brushed decorative elements, 15 incised rim and body sherds (including sherds from Maydelle Incised vessels), eight fingernail punctated sherds, and five engraved sherds from fine ware vessels; two other sherds had what was described on TARL inventory forms as a white slip; 67 percent of the decorated sherds have brushed decorative elements. Johnson (1961:224) noted that the midden deposits, with preserved deer bones, at the site extended to ca. $75 \mathrm{~cm}$ bs.

The TARL collection of sherds from the site includes 70 plain rim, body, and base sherds, 16 utility ware rim and body sherds, and six fine ware rim and body sherds; most of the brushed sherds were not available for analysis. These are from grog- (93.5 percent) and bone- (6.5 percent) tempered vessels.

The utility wares include sherds with parallel brushed $(n=6)$, incised $(n=3)$, incised-punctated $(n=1)$, fingernail punctated $(n=2)$, and tool punctated $(n=4)$ decorative elements. the brushed sherds are from Bullard Brushed sherds, and are apparently part of the Frankston phase component at the site. The other utility wares - and the fine wares - appear to be from a ca. A.D. 1000-1200 occupation at this Saline Creek site, and are likely related to the Early Caddo settlement at the adjacent Joe Meyers Estate \#1 site (cf. Johnson 1961:223). They are comprised of a Dunkin Incised lower rim and upper body sherd with cross-hatched and diagonal opposed incised lines (Figure 12a), a Crockett Curvilinear Incised body sherd (Figure 12b), and two Weches Fingernail Impressed, var. Alto (Stokes and Woodring 1981:185) sherds. Two rim and two body sherds have horizontal rows of tool punctations.

The most distinctive of the fine ware sherds are two grog-tempered body sherds with Holly Fine Engraved decorative elements. One of these sherds has a semi-circular excised area, above which are concentric semi-circular engraved lines (see Figure 12c; see also Suhm and Jelks 1962:Plate 39h). the other has sets of diagonal opposed engraved lines (see Figure 12d). The remaining fine ware sherds include a rim with diagonal engraved lines, a bottle sherd with closely-spaced curvilinear engraved lines (this sherd may be from either a Holly Fine Engraved or Spiro Engraved vessel), and body sherds with either opposed engraved lines or a single engraved line. 


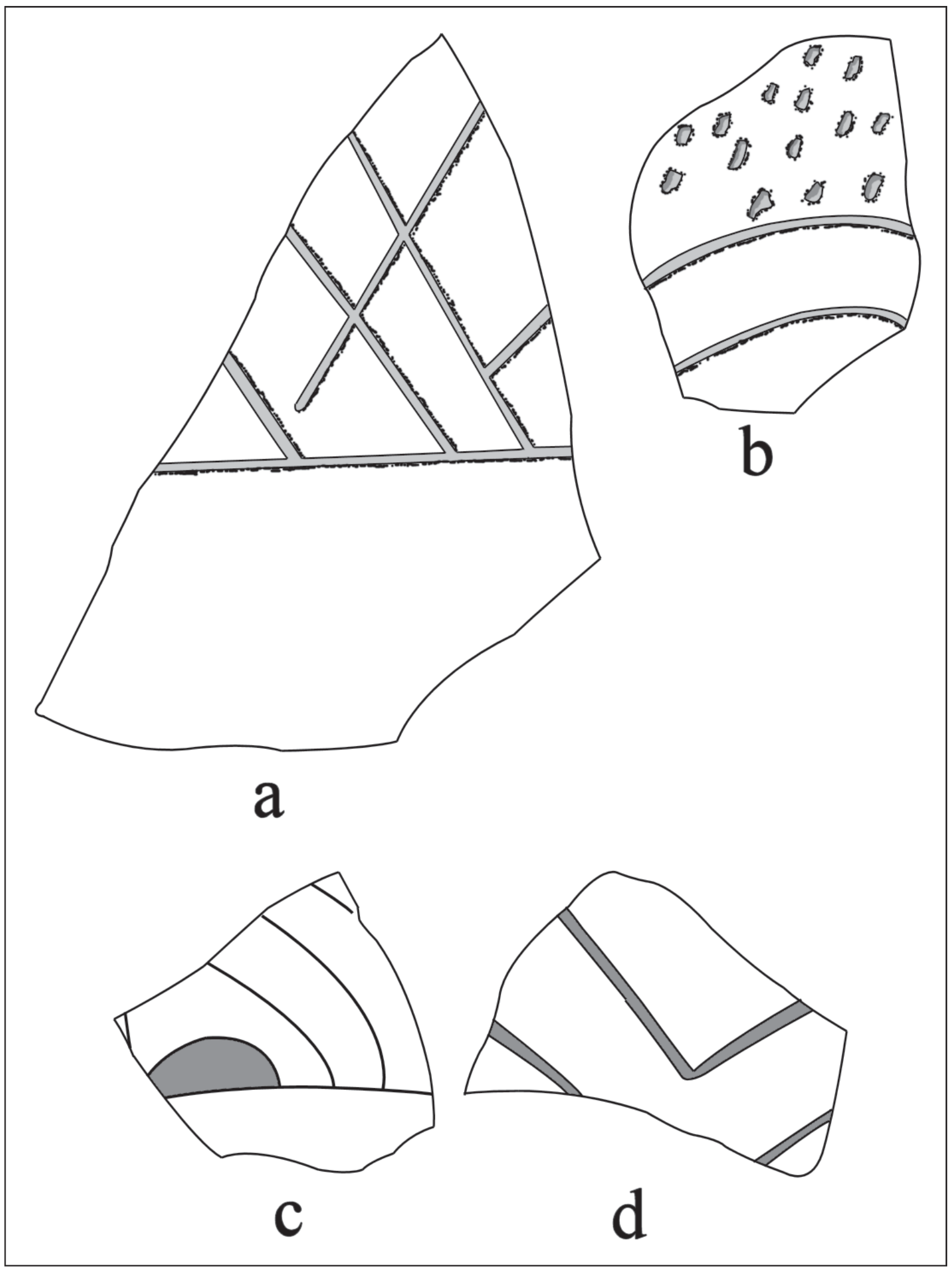

Figure 12. Decorative elements on utility ware and fine ware sherds from 41SM76. 


\section{Vanderpool (41SM77)}

The Vanderpool site, also referred to by Buddy Calvin Jones as the FIN site in Smith County, is on Saline Creek in the Neches River basin in the southwestern part of the county, in the western part of the East Texas Pineywoods (see Figure 2). It is known that a Mr. Wallace and a Mr. Vanderpool excavated two burials at the site in 1957 (Johnson 1961:224), and both these individuals dug at the Saline Creek site in 1956 with Jones (see below). Johnson (1961) noted that the two burials had contained 10 Frankston phase (ca. A.D. 1400-1650) ceramic vessels, 14 Perdiz arrow points, a celt, and one large chipped stone knive. The vessels included two Poynor Engraved carinated bowls, a Poynor Engraved bowl, three Hood Engraved effigy bowls, a plain bowl, and three bottles (one plain, and the other two Hume Engraved and Poynor Engraved bottles).

According to Jones' notes, a total of five burials were excavated at the Vanderpool site (Burials 1-5). However, his notes only concern Burials 1, 3-5, and even these notes are not extensive. Burials 3 and 4 were oriented east-west and were close together, and Burial 5 was more than $30 \mathrm{~m}$ to the south. His notes for Burial 3 indicate that the deceased Caddo individual was placed in a grave that was $76 \mathrm{~cm}$ in depth, $107 \mathrm{~cm}$ in width, and $203 \mathrm{~cm}$ in length. The burial fill was a lightly-colored sandy soil, indicating that Burial 3 had not been placed in a midden deposit.

Jones' burial pottery catalogue for the Vanderpool site lists a total of 34 ceramic vessels in four of the burials: two ceramic vessels as associated funerary offerings in Burial 1, 14 ceramic vessels in Burial 3,12 vessels in Burial 4, and six ceramic vessels in Burial 5. This is a mean of 8.5 ceramic vessels per burial in the cemetery.

\section{Burial 1}

There is one ceramic vessel in the Vanderpool site collections from Burial 1, although Jones' burial pottery catalogue lists two (SC 1 and SC 2):

VESSEL NO.: 2003.08.223 (FIN SC 2)

NON-PLASTICS AND PASTE: grog and bone

VESSEL FORM: Bowl with four rim peaks

RIM AND LIP FORM: Direct rim and rounded lip

CORE COLOR: F (fired in a reducing environment and cooled in the open air)

INTERIOR SURFACE COLOR: reddish-brown

EXTERIOR SURFACE COLOR: reddish-brown; fire clouds on the body and base; organic residue on the body

WALL THICKNESS (RIM, BODY, AND BASE IN MM): rim, $6.7 \mathrm{~mm}$; base, $11.0 \mathrm{~mm}$

INTERIOR SURFACE TREATMENT: smoothed

EXTERIOR SURFACE TREATMENT: burnished

HEIGHT (IN CM): 8.7; $9.7 \mathrm{~cm}$ atop the rim peaks 
ORIFICE DIAMETER (IN CM): 16.9

DIAMETER AT BOTTOM OF RIM OR

NECK (IN CM): N/A

BASE DIAMETER (IN CM) AND SHAPE

OF BASE: 7.4; circular and flat

ESTIMATED VOLUME (IN LITERS):

0.59

DECORATION (INCLUDING MOTIF AND ELEMENTS WHEN APPARENT): Plain (Figure 13)

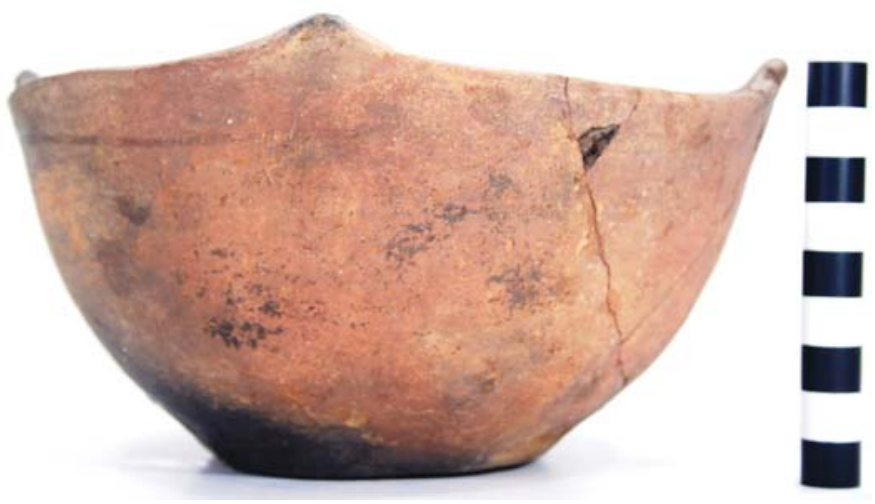

Figure 13. Plain bowl from Burial 1 at the Vanderpool site.

PIGMENT USE AND LOCATION ON VESSEL: none

TYPE AND VARIETY [IF KNOWN]: Unidentified plain ware

\section{Burial 3}

Burial 3 is that of an adult placed in an extended supine position with its head at the eastern end of the grave, and facing west (Figure 14). The many vessels in the grave were apparently placed in rows along both side of the body, from the head down to the feet. Two distinctive engraved jars (FIN S5 and S6) were by the head and the left shoulder, while two bottles were placed by the right shoulder. A mixture of bowls and jars were along what would have been the body mid-section and the legs. The locations of the glass beads, ceramic pipe, and arrow point within the grave pit are not known, as they were not depicted on Jones' burial drawing (see Figure 14).

Thirteen of the 14 ceramic vessels that had been placed in Burial 3 are in the Vanderpool site collections at the Gregg County Historical Museum. The one missing vessel is FIN S8, which is described in Jones' burial pottery catalogue as a "quadrapod pot." This may mean a vessel with four rim peaks.

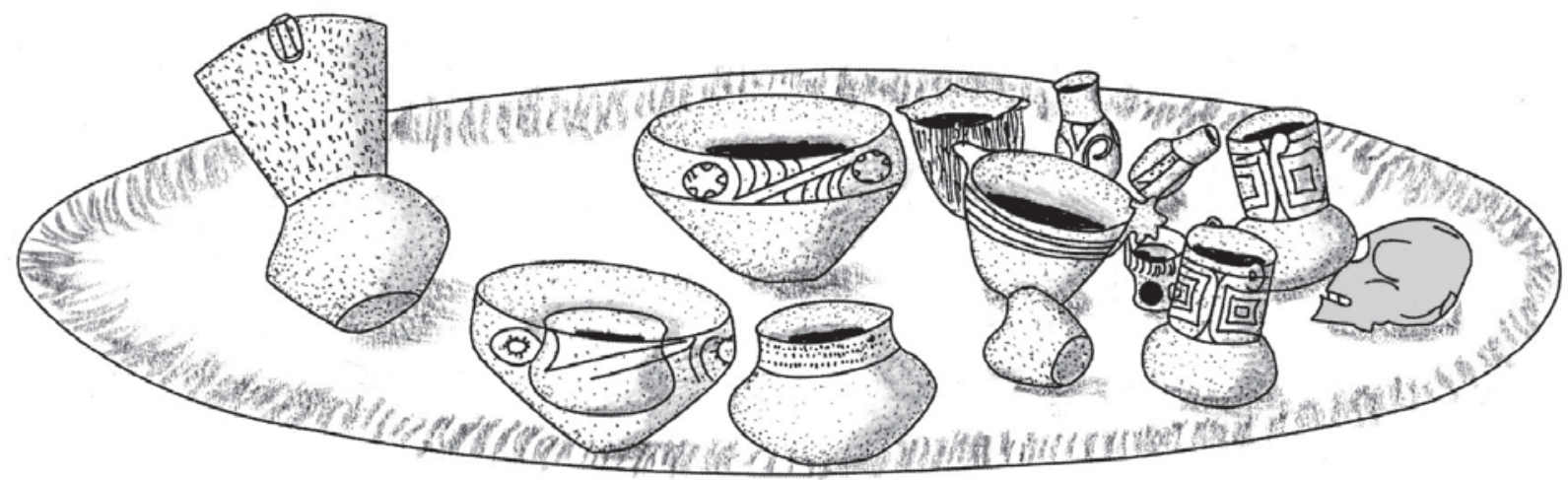

Figure 14. Burial 3 at the Vanderpool site. 
VESSEL NO.: 2003.08.268 (FIN S3)

NON-PLASTICS AND PASTE: bone

VESSEL FORM: Bottle

RIM AND LIP FORM: Direct rim and rounded lip

CORE COLOR: A (fired and cooled in an oxidizing environment)

INTERIOR SURFACE COLOR: reddish-brown

EXTERIOR SURFACE COLOR: reddish-brown

WALL THICKNESS (RIM, BODY, AND BASE IN MM): rim, $4.1 \mathrm{~mm}$

INTERIOR SURFACE TREATMENT: none

EXTERIOR SURFACE TREATMENT: smoothed

HEIGHT (IN CM): 12.3

ORIFICE DIAMETER (IN CM): 3.3

DIAMETER AT BOTTOM OF RIM OR NECK (IN CM): 5.3

BASE DIAMETER (IN CM) AND SHAPE OF BASE: 5.1; circular and flat

ESTIMATED VOLUME (IN LITERS): 0.26

DECORATION (INCLUDING MOTIF AND ELEMENTS WHEN APPARENT): The vessel body has seven narrow vertical panels filled with crosshatched engraved lines. The panels extend from the base of the bottle neck to just above the base, where there is a single horizontal engraved line (Figure 15).

\section{PIGMENT USE AND LOCATION ON}

VESSEL: none

TYPE AND VARIETY [IF KNOWN]:

Hume Engraved, var. Hume

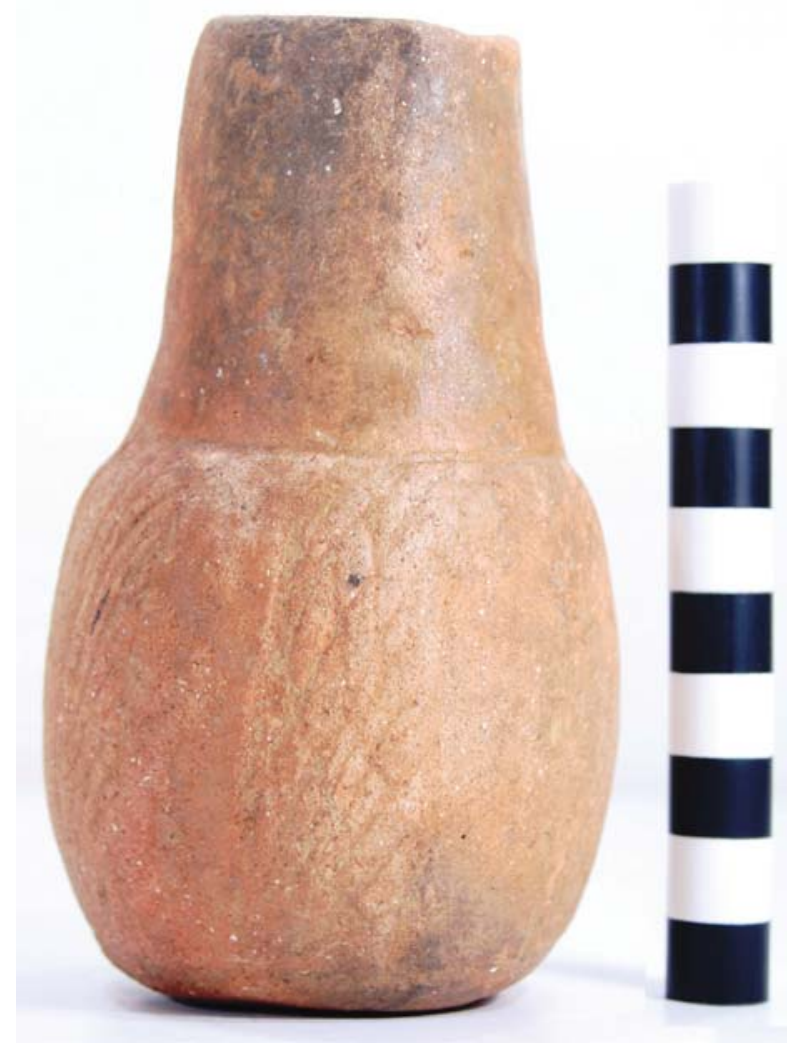

Figure 15. Hume Engraved, var. Hume bottle from Burial 3 at the Vanderpool site. 
VESSEL NO.: 2003.08.1828 (FIN S4)

NON-PLASTICS AND PASTE: grog

VESSEL FORM: Bottle

RIM AND LIP FORM: Direct rim and a flat lip

CORE COLOR: A (fired and cooled in an oxidizing environment)

INTERIOR SURFACE COLOR: yellowish-brown

EXTERIOR SURFACE COLOR: yellowish-brown; fire clouds on the body and base

WALL THICKNESS (RIM, BODY, AND BASE IN MM): rim, $6.3 \mathrm{~mm}$

INTERIOR SURFACE TREATMENT: none

EXTERIOR SURFACE TREATMENT: burnished

HEIGHT (IN CM): 16.2

ORIFICE DIAMETER (IN CM): 4.4

DIAMETER AT BOTTOM OF RIM OR

NECK (IN CM): 5.9; maximum width on the body is $9.6 \mathrm{~cm}$

BASE DIAMETER (IN CM) AND

SHAPE OF BASE: 7.2; circular and flat

ESTIMATED VOLUME (IN LITERS): 0.46

\section{DECORATION (INCLUDING MOTIF} AND ELEMENTS WHEN APPARENT): The engraved motif on the vessel body is delimited by two sets of upper and lower horizontal engraved lines. The two body panels have hooked arm elements and a slanted scroll, along with hatched triangular elements, with the scroll fill zones filled with negative ovals defined by hatched and cross-hatched areas (Figure 16).

PIGMENT USE AND LOCATION ON VESSEL: none

TYPE AND VARIETY [IF KNOWN]: Unidentified fine ware

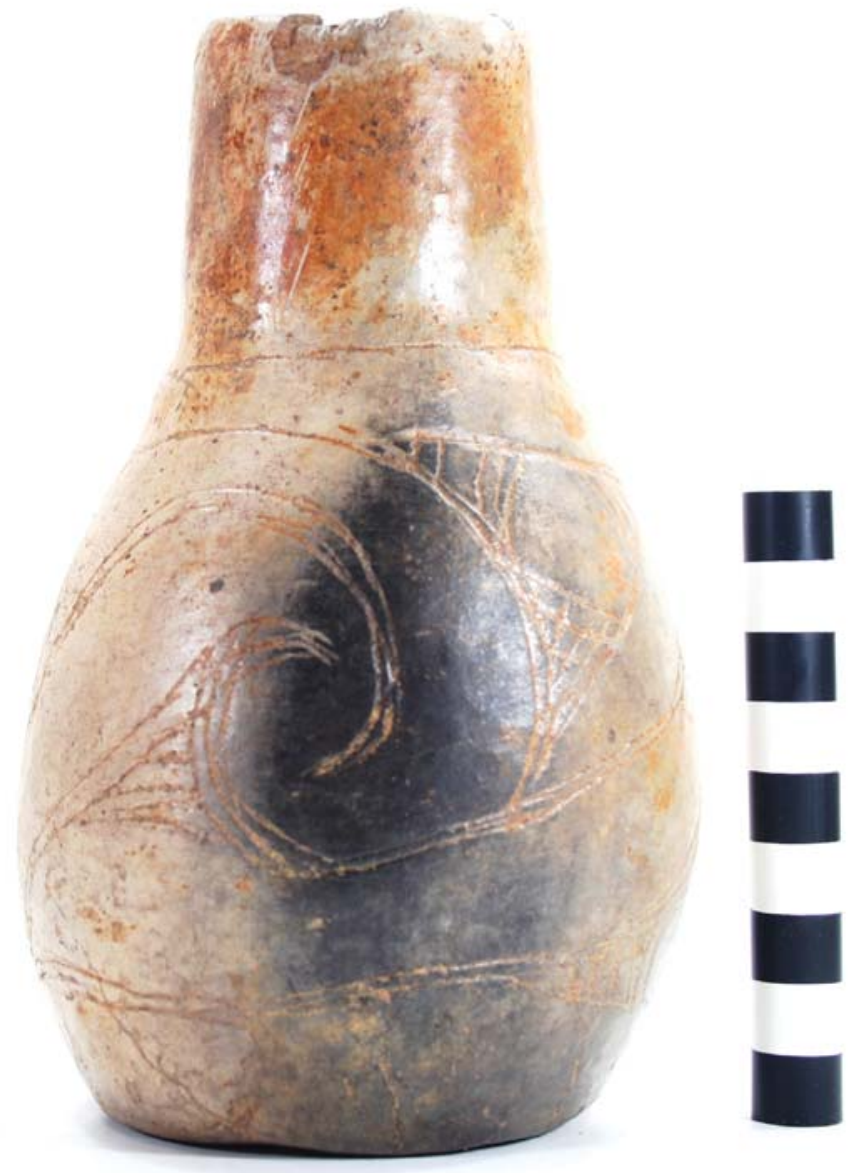

Figure 16. Engraved bottle (FIN S4) from Burial 3 at the Vanderpool site. 
VESSEL NO.: 2003.08.363 (FIN S5)

NON-PLASTICS AND PASTE: grog and hematite

VESSEL FORM: Jar with two loop handles (28 x $14 \mathrm{~mm}$ in length and width) (Figure 17)

RIM AND LIP FORM: Direct rim and rounded lip

CORE COLOR: A (fired and cooled in an oxidizing environment)

INTERIOR SURFACE COLOR: yellowish-brown; fire clouds on the body and base

EXTERIOR SURFACE COLOR: yellowish-brown; fire clouds on the body and base

WALL THICKNESS (RIM, BODY, AND BASE IN MM): rim, $5.6 \mathrm{~mm}$

INTERIOR SURFACE TREATMENT: smoothed

EXTERIOR SURFACE TREATMENT: burnished

HEIGHT (IN CM): 13.7

ORIFICE DIAMETER (IN CM): 10.4

DIAMETER AT BOTTOM OF RIM OR NECK (IN CM): 10.5

BASE DIAMETER (IN CM) AND SHAPE OF BASE: 7.8; circular and flat

ESTIMATED VOLUME (IN LITERS):

0.85

DECORATION (INCLUDING MOTIF AND ELEMENTS WHEN APPARENT): The tall rim has four engraved rectangular panels divided by vertical brackets; there are small hatched triangles at the top and bottom of each bracket. Within each of the panels are two interior sets of engraved rectangles (Figure 17).

\section{PIGMENT USE AND LOCATION ON}

VESSEL: white pigment in the engraved lines

TYPE AND VARIETY [IF KNOWN]: cf. Poynor Engraved, var. Blackburn

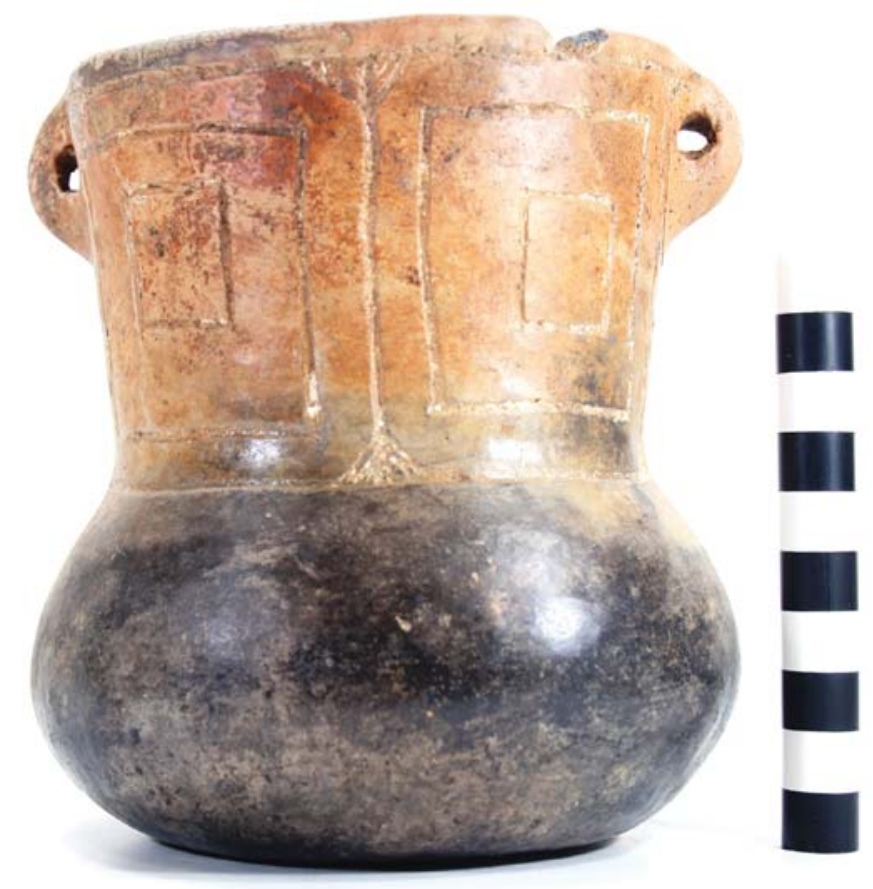

Figure 17. cf. Poynor Engraved, var. Blackburn jar (FIN S5), Burial 3 at the Vanderpool site. 
VESSEL NO.: 2003.08.0003 (FIN S6)

NON-PLASTICS AND PASTE: bone

VESSEL FORM: Jar with two loop handles (24 x $9 \mathrm{~mm}$ in length and width) (Figure 18)

RIM AND LIP FORM: Direct rim and rounded lip

CORE COLOR: $\mathrm{F}$ (fired in a reducing environment and cooled in the open air)

INTERIOR SURFACE COLOR: dark yellowish-brown; fire clouds on the rim, body, and base

EXTERIOR SURFACE COLOR: dark yellowish-brown; fire clouds on the rim, body, and base

WALL THICKNESS (RIM, BODY, AND BASE IN MM): rim, $5.6 \mathrm{~mm}$

INTERIOR SURFACE TREATMENT: smoothed

EXTERIOR SURFACE TREATMENT: burnished

HEIGHT (IN CM): 14.9

ORIFICE DIAMETER (IN CM): 11.0

DIAMETER AT BOTTOM OF RIM OR NECK (IN CM): 10.8

BASE DIAMETER (IN CM) AND SHAPE OF BASE: 7.1; circular and rounded

ESTIMATED VOLUME (IN LITERS): 0.98

DECORATION (INCLUDING MOTIF AND ELEMENTS WHEN APPARENT): The tall rim has four engraved rectangular panels divided by vertical brackets; there are small excised triangles on either side of the divider at the top and bottom of each bracket. Within each of the panels are three interior sets of engraved rectangles (Figure 18). The decoration on this jar is virtually identical to that on FIN S5 (see Figure 17).

PIGMENT USE AND LOCATION ON

VESSEL: red pigment in the engraved lines

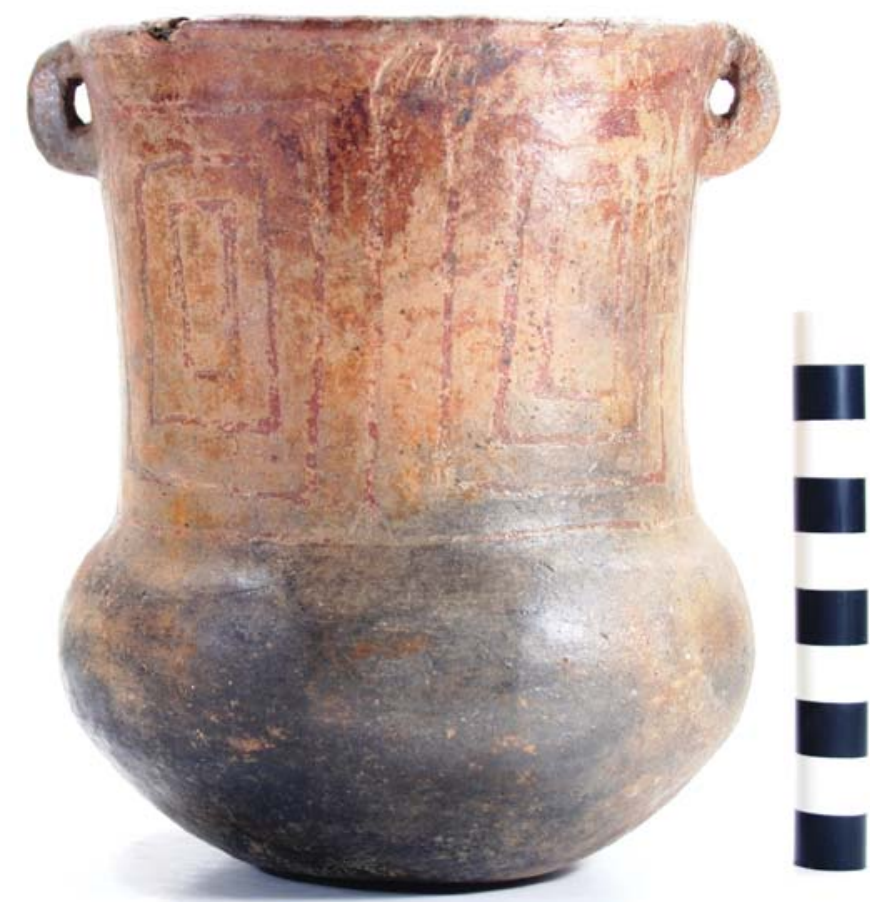

Figure 18. cf. Poynor Engraved, var. Blackburn jar (FIN S6), Burial 3 at the Vanderpool site.

TYPE AND VARIETY [IF KNOWN]: cf. Poynor Engraved, var. Blackburn 
VESSEL NO.: 2003.08.0004 (FIN S7)

NON-PLASTICS AND PASTE: grog

VESSEL FORM: Bowl with bird effigy head $(7.6 \times 1.0 \mathrm{~cm}$ in height and width) and tab tail $(5.0 \times 3.0$ $\mathrm{cm}$ ) (Figure 19)

RIM AND LIP FORM: Direct rim and rounded lip

CORE COLOR: F (fired in a reducing environment and cooled in the open air)

INTERIOR SURFACE COLOR: light yellowish-brown; fire clouds on the rim, body, and base

EXTERIOR SURFACE COLOR: brown; fire clouds on the rim, body, and base

WALL THICKNESS (RIM, BODY, AND BASE IN MM): rim, $6.2 \mathrm{~mm}$

INTERIOR SURFACE TREATMENT: burnished

EXTERIOR SURFACE TREATMENT: burnished

HEIGHT (IN CM): $10.8 ; 13.3 \mathrm{~cm}$ at the top of the effigy head

ORIFICE DIAMETER (IN CM): 18.4

DIAMETER AT BOTTOM OF RIM OR NECK (IN CM): N/A

BASE DIAMETER (IN CM) AND SHAPE OF BASE: 10.9; circular and flat

ESTIMATED VOLUME (IN LITERS): 0.80

DECORATION (INCLUDING MOTIF AND ELEMENTS WHEN APPARENT):

The vessel has three sets of horizontal engraved lines that encircle the rim (Figure 19), except under the effigy head and tab tail.

PIGMENT USE AND LOCATION ON

VESSEL: none

TYPE AND VARIETY [IF KNOWN]:

Hood Engraved, var. Hood

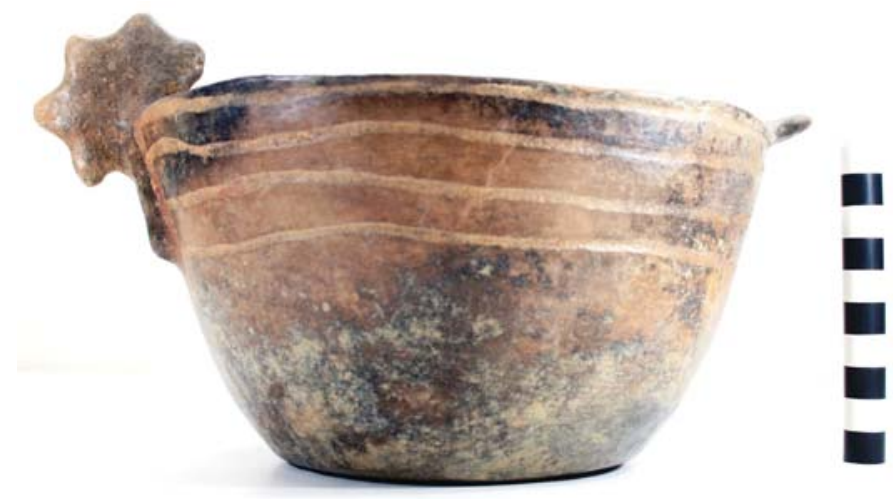

Figure 19. Hood Engraved, var. Hood effigy bowl, Burial 3 at the Vanderpool site. 
VESSEL NO.: 2003.08.579 (FIN S9)

NON-PLASTICS AND PASTE: bone

VESSEL FORM: Jar

RIM AND LIP FORM: N/A

CORE COLOR: F (fired in a reducing environment and cooled in the open air)

INTERIOR SURFACE COLOR: reddish-brown

EXTERIOR SURFACE COLOR: brown

WALL THICKNESS (RIM, BODY, AND BASE IN MM): body, $7.1 \mathrm{~mm}$

INTERIOR SURFACE TREATMENT: none

EXTERIOR SURFACE TREATMENT: none

HEIGHT (IN CM): 9.5+

ORIFICE DIAMETER (IN CM): 12.7

DIAMETER AT BOTTOM OF RIM OR NECK (IN CM): N/A

BASE DIAMETER (IN CM) AND SHAPE

OF BASE: 5.7 ; circular and flat

ESTIMATED VOLUME (IN LITERS):

$0.72+$

DECORATION (INCLUDING MOTIF AND ELEMENTS WHEN APPARENT):

The vessel has vertical brushing on the body (Figure 20).

PIGMENT USE AND LOCATION ON

VESSEL: none

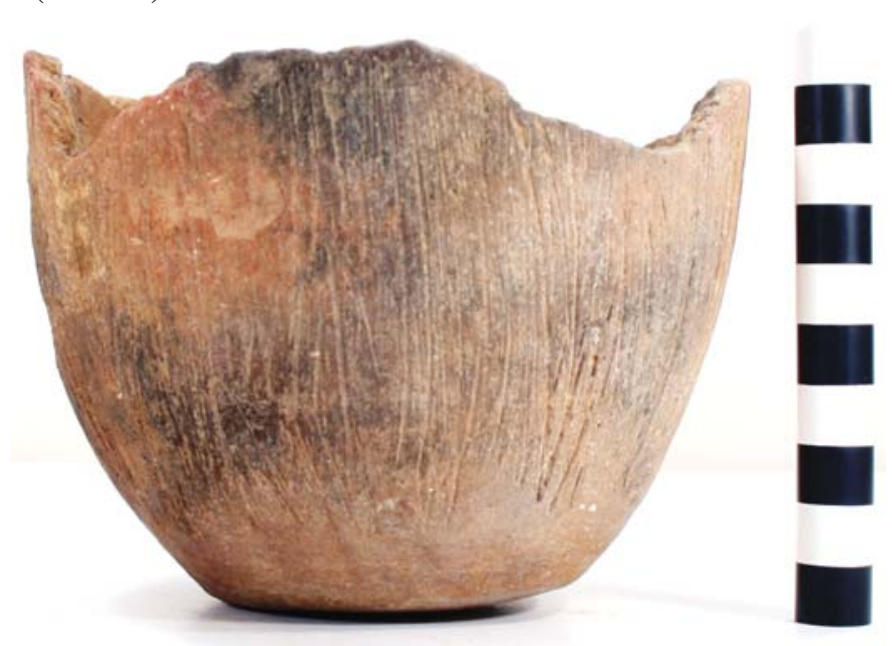

Figure 20. Fragmentary Bullard Brushed jar from Burial 3

at the Vanderpool site.
TYPE AND VARIETY [IF KNOWN]:

Bullard Brushed 
VESSEL NO.: 2003.08.0018 (FIN S10)

NON-PLASTICS AND PASTE: grog

VESSEL FORM: Carinated bowl

RIM AND LIP FORM: Direct rim and a rounded lip

CORE COLOR: A (fired and cooled in an oxidizing environment)

INTERIOR SURFACE COLOR: dark reddish-brown; fire clouds on the body

EXTERIOR SURFACE COLOR: dark reddish-brown; fire clouds on the rim, body, and base

WALL THICKNESS (RIM, BODY, AND BASE IN MM): rim, $4.6 \mathrm{~mm}$

INTERIOR SURFACE TREATMENT: burnished

EXTERIOR SURFACE TREATMENT: burnished

HEIGHT (IN CM): 13.6

ORIFICE DIAMETER (IN CM): 17.2

DIAMETER AT BOTTOM OF RIM OR NECK (IN CM): 17.1

BASE DIAMETER (IN CM) AND SHAPE

OF BASE: 8.2; circular and flat

ESTIMATED VOLUME (IN LITERS): 2.1

DECORATION (INCLUDING MOTIF AND ELEMENTS WHEN APPARENT):

The rim has three regularly spaced horizontal engraved lines with hatched triangular tick marks. The middle horizontal engraved lines has two sets of hatched triangles, with the apexes of the triangles pointing either towards the rim or the carination (Figure 21).

PIGMENT USE AND LOCATION ON VESSEL: none

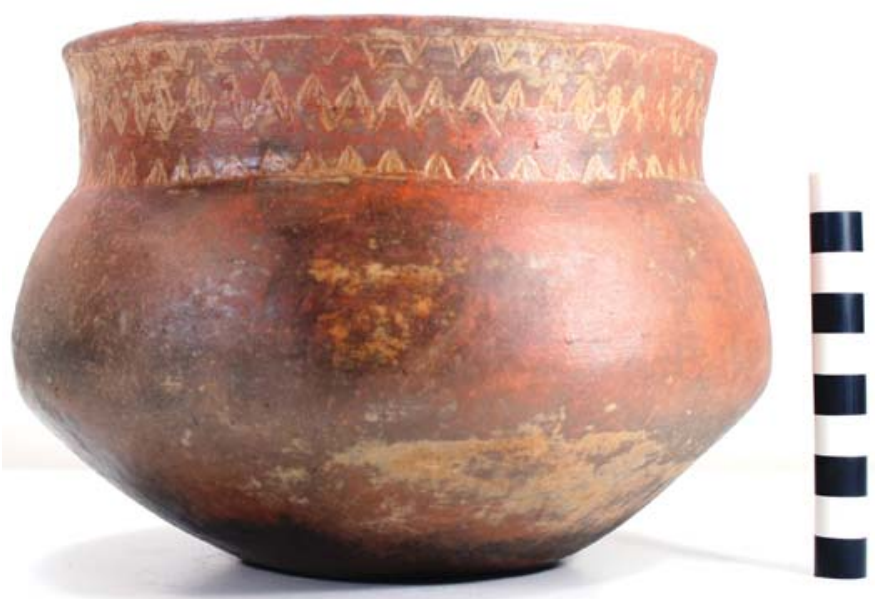

Figure 21. Patton Engraved, var. Allen carinated bowl, Burial 3 at the Vanderpool site.

TYPE AND VARIETY [IF KNOWN]: Patton Engraved, var. Allen 
VESSEL NO.: 2003.08.272 (FIN S11)

NON-PLASTICS AND PASTE: grog and hematite

VESSEL FORM: Globular carinated bowl

RIM AND LIP FORM: Everted rim and a rounded lip

CORE COLOR: A (fired and cooled in an oxidizing environment)

INTERIOR SURFACE COLOR: dark yellowish-brown

EXTERIOR SURFACE COLOR: dark yellowish-brown; organic residue on rim and body

WALL THICKNESS (RIM, BODY, AND BASE IN MM): rim, 5.8 mm

INTERIOR SURFACE TREATMENT: burnished on the rim, smoothed on the body

EXTERIOR SURFACE TREATMENT: burnished

HEIGHT (IN CM): 12.6

ORIFICE DIAMETER (IN CM): 15.9

DIAMETER AT BOTTOM OF RIM OR NECK (IN CM): 15.7

BASE DIAMETER (IN CM) AND SHAPE OF BASE: 8.3; flat and circular

ESTIMATED VOLUME (IN LITERS): 1.2

DECORATION (INCLUDING MOTIF AND ELEMENTS WHEN APPARENT): The rim is divided into eight oval-shaped panels by vertical excised brackets. The top and bottom of the panel is marked by single horizontal engraved lines (Figure 22).

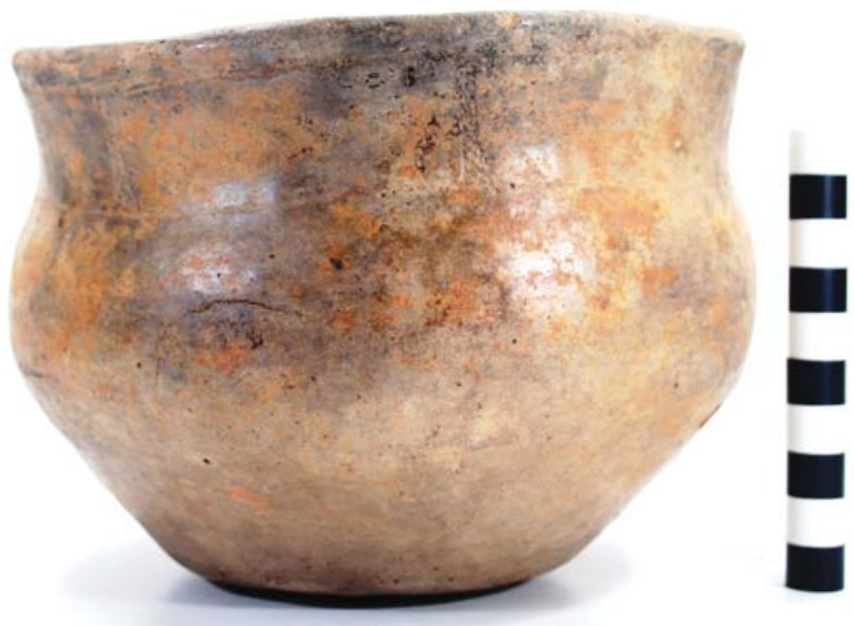

Figure 22. Poynor Engraved, var. Hood carinated bowl, Burial 3 at the Vanderpool site.

PIGMENT USE AND LOCATION ON VESSEL: none

TYPE AND VARIETY [IF KNOWN]: Poynor Engraved, var. Hood 
VESSEL NO.: 2003.08.350 (FIN 12)

NON-PLASTICS AND PASTE: grog and hematite

VESSEL FORM: Carinated bowl

RIM AND LIP FORM: Inverted rim and rounded lip

CORE COLOR: F (fired in a reducing environment and cooled in the open air)

INTERIOR SURFACE COLOR: dark yellowish-brown; fire clouds and organic residue on the rim and body

EXTERIOR SURFACE COLOR: dark yellowish-brown; fire clouds on the rim and body

WALL THICKNESS (RIM, BODY, AND BASE IN MM): rim, $6.7 \mathrm{~mm}$

INTERIOR SURFACE TREATMENT: smoothed

EXTERIOR SURFACE TREATMENT: burnished

HEIGHT (IN CM): 15.9

ORIFICE DIAMETER (IN CM): 27.5

DIAMETER AT BOTTOM OF RIM OR NECK (IN CM): 28.0

BASE DIAMETER (IN CM) AND SHAPE OF BASE: 10.0; flat and circular

ESTIMATED VOLUME (IN LITERS): 4.0

DECORATION (INCLUDING MOTIF AND ELEMENTS WHEN APPARENT):

The rim panel has an engraved slanted scroll and circle motif repeated four times around the vessel. The central circle element has a small inner circle with excised triangular-shaped rays. The upper and lower scroll fill zones are open (Figure 23).

\section{PIGMENT USE AND LOCATION ON} VESSEL: none

TYPE AND VARIETY [IF KNOWN]: Poynor Engraved, Var. E (see Perttula 2011:Figure 6-65)

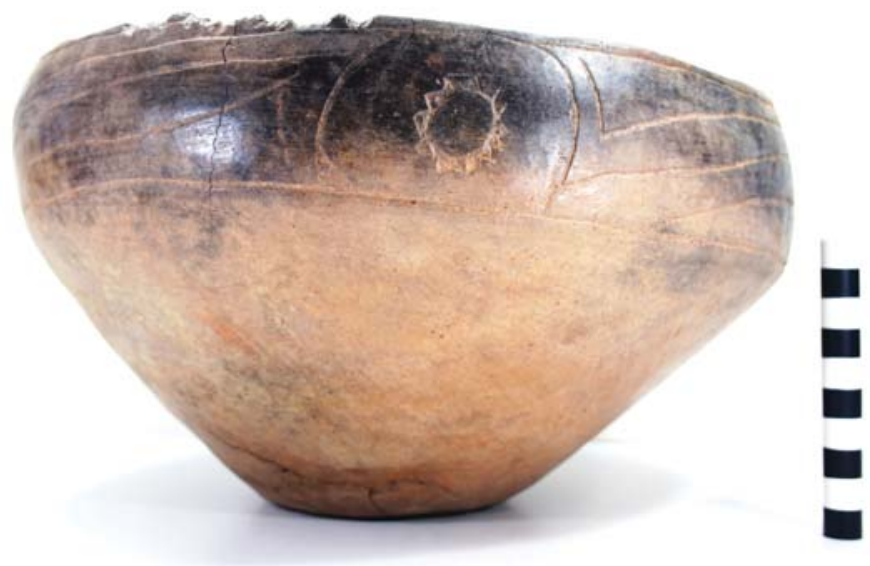

Figure 23. Poynor Engraved, Var. E carinated bowl, Burial 3 at the Vanderpool site. 
VESSEL NO.: 2003.08.0002 (FIN S13)

NON-PLASTICS AND PASTE: grog

VESSEL FORM: Jar with a tall rim, and two strap handles (32 x $20 \mathrm{~mm}$ in length and width) and a carinated body (Figure 24)

RIM AND LIP FORM: Everted rim and a rounded lip

CORE COLOR: $\mathrm{F}$ (fired in a reducing environment and cooled in the open air)

INTERIOR SURFACE COLOR: dark reddish-brown; fire clouds on the rim, body, and base

EXTERIOR SURFACE COLOR: reddish-brown; fire clouds on the rim, body, and base

WALL THICKNESS (RIM, BODY, AND BASE IN MM): rim, $7.0 \mathrm{~mm}$

INTERIOR SURFACE TREATMENT:

smoothed

EXTERIOR SURFACE TREATMENT: none

HEIGHT (IN CM): 27.5

ORIFICE DIAMETER (IN CM): 22.9

DIAMETER AT BOTTOM OF RIM OR

NECK (IN CM): 25.6

BASE DIAMETER (IN CM) AND SHAPE

OF BASE: 10.0; circular and flat

ESTIMATED VOLUME (IN LITERS): 8.2

DECORATION (INCLUDING MOTIF AND

ELEMENTS WHEN APPARENT): The vessel rim has 14 horizontal rows of tool punctations. The vessel body has horizontal brushing marks that extend to near the base (Figure 24).

PIGMENT USE AND LOCATION ON VESSEL: none

TYPE AND VARIETY [IF KNOWN]:

Unidentified utility ware

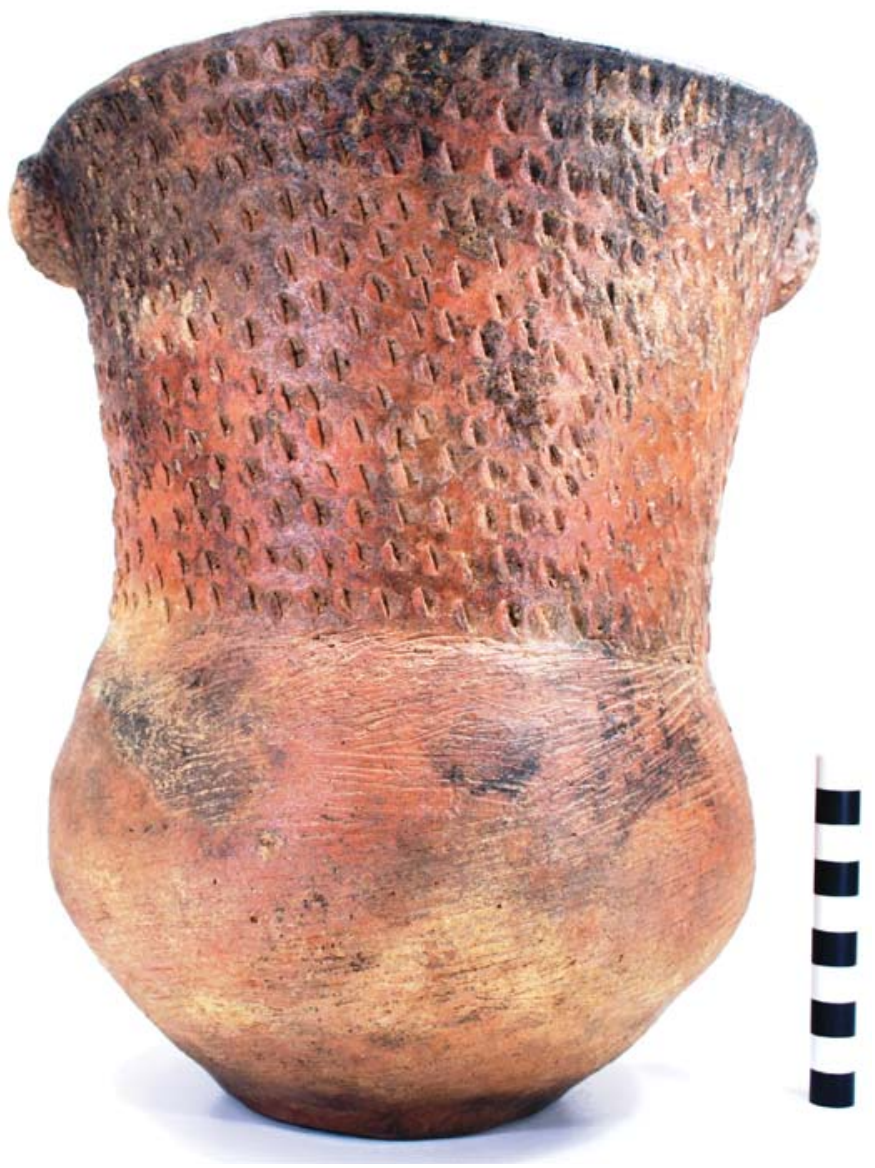

Figure 24. Punctated-brushed jar from Burial 3 at the Vanderpool site. 
VESSEL NO.: 2003.08.1005 (FIN S14)

NON-PLASTICS AND PASTE: grog

VESSEL FORM: Bowl

RIM AND LIP FORM: Direct rim and a rounded lip

CORE COLOR: B (fired and cooled in a reducing environment)

INTERIOR SURFACE COLOR: dark grayish-brown; fire clouds on the rim

EXTERIOR SURFACE COLOR: very dark grayish-brown; fire clouds and organic residue on the rim and body

WALL THICKNESS (RIM, BODY, AND BASE IN MM): rim, $8.2 \mathrm{~mm}$

INTERIOR SURFACE TREATMENT: burnished

EXTERIOR SURFACE TREATMENT: smoothed

HEIGHT (IN CM): 8.0

ORIFICE DIAMETER (IN CM): 15.4

DIAMETER AT BOTTOM OF RIM OR NECK (IN CM): N/A

BASE DIAMETER (IN CM) AND SHAPE OF BASE: 9.2; circular and rounded

ESTIMATED VOLUME (IN LITERS): 0.49

DECORATION (INCLUDING MOTIF AND ELEMENTS WHEN APPARENT):

The rim has four oval-shaped panels defined by opposing sets of three vertically arcing engraved lines. There are small hatched triangles at the top of each of the panels (Figure 25).

\section{PIGMENT USE AND LOCATION ON}

VESSEL: none

TYPE AND VARIETY [IF KNOWN]:

Patton Engraved, var. unspecified

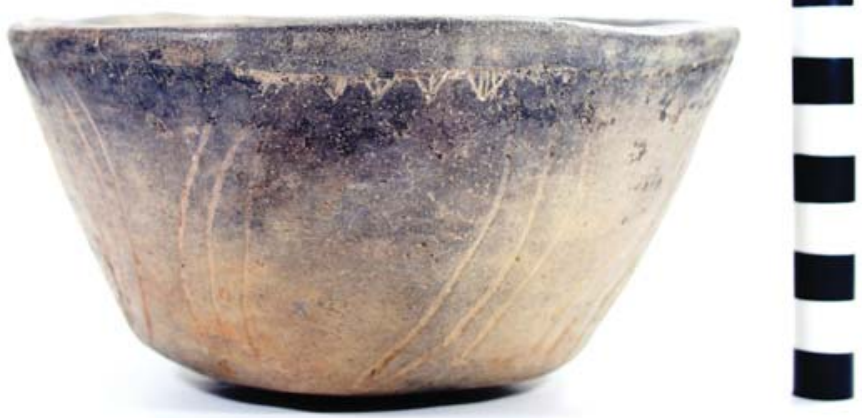

Figure 25. Patton Engraved, var. unspecified bowl from Burial 3 at the Vanderpool site. 
VESSEL NO.: 2003.08.0007 (FIN S15)

NON-PLASTICS AND PASTE: bone

VESSEL FORM: Jar with four lip lugs (Figure 26)

RIM AND LIP FORM: Direct rim and rounded lip

CORE COLOR: $\mathrm{F}$ (fired in a reducing environment and cooled in the open air)

INTERIOR SURFACE COLOR: reddish-brown

EXTERIOR SURFACE COLOR: dark reddish-brown; fire clouds and organic residue on the rim and body

WALL THICKNESS (RIM, BODY, AND BASE IN MM): rim, 6.0 mm

INTERIOR SURFACE TREATMENT: smoothed

EXTERIOR SURFACE TREATMENT: none

HEIGHT (IN CM): $14.0 ; 14.6 \mathrm{~cm}$ in height atop the lugs

ORIFICE DIAMETER (IN CM): 16.3

DIAMETER AT BOTTOM OF RIM OR NECK (IN CM): 14.0

BASE DIAMETER (IN CM) AND SHAPE

OF BASE: 7.2; circular and flat

ESTIMATED VOLUME (IN LITERS): 1.4

DECORATION (INCLUDING MOTIF AND ELEMENTS WHEN APPARENT):

There are vertical brushing marks from the rim to the vessel base (Figure 26).

PIGMENT USE AND LOCATION ON

VESSEL: none

TYPE AND VARIETY [IF KNOWN]:

Bullard Brushed

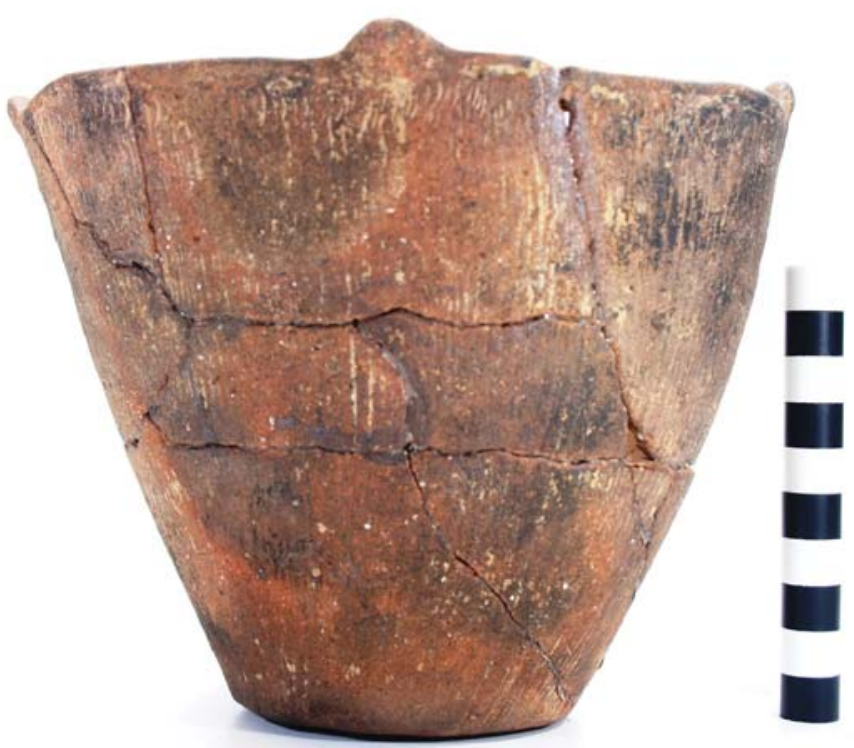

Figure 26. Bullard Brushed jar, Burial 3 at the Vanderpool site. 
VESSEL NO.: 2003.08.0885 (FIN S16)

NON-PLASTICS AND PASTE: grog and hematite

VESSEL FORM: Carinated bowl

RIM AND LIP FORM: Inverted rim and rounded lip

CORE COLOR: $\mathrm{H}$ (fired in a reducing environment and cooled in the open air)

INTERIOR SURFACE COLOR: reddish-brown; fire clouds on the rim and body

EXTERIOR SURFACE COLOR: grayish-brown

WALL THICKNESS (RIM, BODY, AND BASE IN MM): rim, $8.1 \mathrm{~mm}$; body, $8.6 \mathrm{~mm}$

INTERIOR SURFACE TREATMENT: none

EXTERIOR SURFACE TREATMENT: smoothed

HEIGHT (IN CM): 20.3

ORIFICE DIAMETER (IN CM): 30.6

DIAMETER AT BOTTOM OF RIM OR NECK (IN CM): 31.2

BASE DIAMETER (IN CM) AND SHAPE OF BASE: 11.3; circular and flat

ESTIMATED VOLUME (IN LITERS): 5.6

DECORATION (INCLUDING MOTIF AND ELEMENTS WHEN APPARENT):

The rim panel, as defined by single upper and lower horizontal engraved lines, has an engraved circle and slanting scroll motif repeated six times around the vessel. The central circle element has a smaller internal circle with a series of six hatched pendant triangles whose apexes point towards the center of this small circle. The upper and lower scroll fill zones have curvilinear engraved lines (Figure 27).

PIGMENT USE AND LOCATION ON

VESSEL: red pigment in the engraved lines

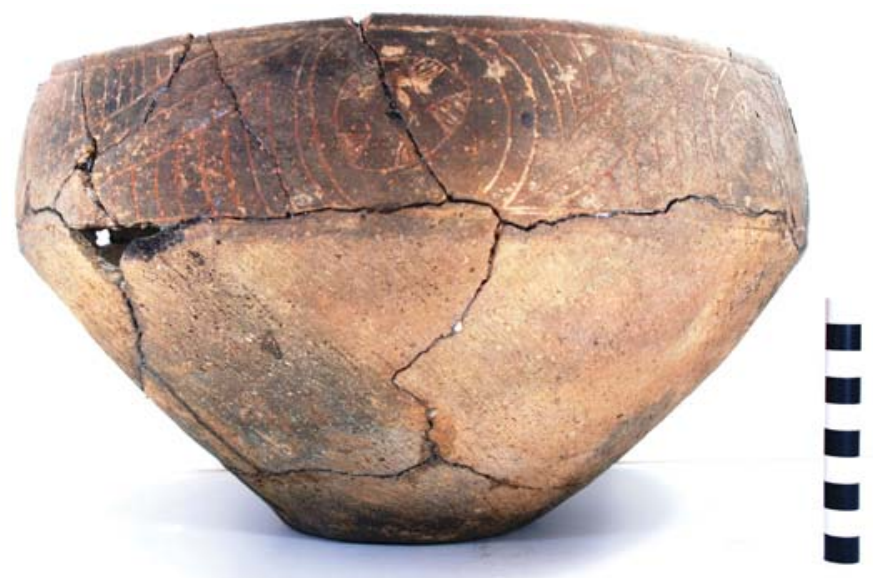

Figure 27. Poynor Engraved, Var. $E$ carinated bowl (FIN S16), Burial 3 at the Vanderpool site.

TYPE AND VARIETY [IF KNOWN]: Poynor Engraved, Var. E 


\section{Ceramic Pipe}

A keeled ceramic elbow pipe (2003.08.120, SC 14/60) was also placed in Burial 3 as a funerary offering. The pipe is tempered with grog and has a sandy paste. It is $65.2 \mathrm{~mm}$ in length and $35.0 \mathrm{~mm}$ in width. The bowl is $14.1 \mathrm{~mm}$ in height, with a $35.8 \mathrm{~mm}$ orifice diameter. The exterior diameter of the stem is $28.7 \mathrm{~mm}$, and it is $7.6 \mathrm{~mm}$ in thickness. The pipe stem is decorated with a series of hatched ovals and triangles (Figure 28). This form of decorated elbow pipe is previously undocumented in upper Neches River basin Caddo sites (see Perttula 2011:Figure 6-23).

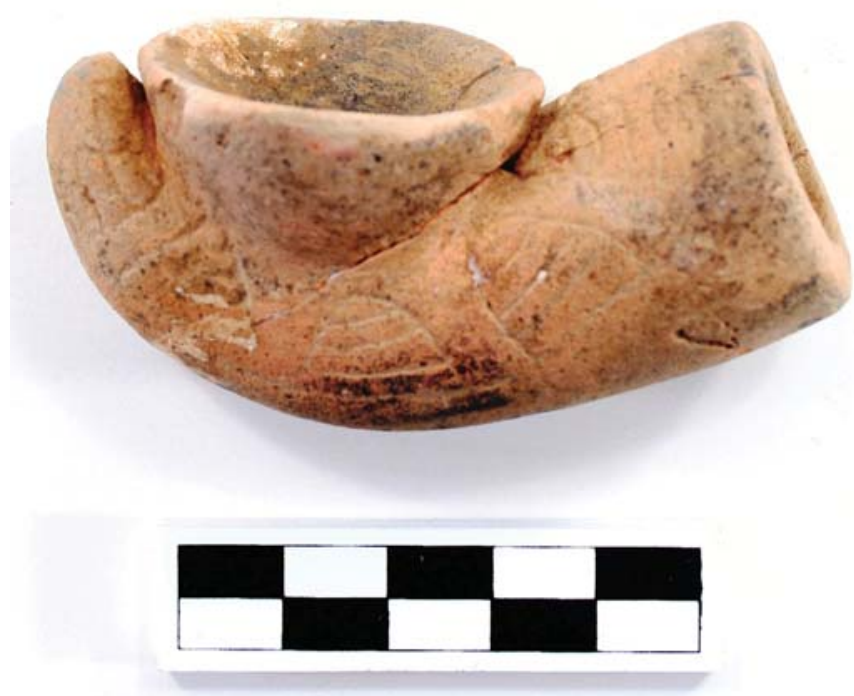

Figure 28. Elbow pipe in Burial 3 at the Vanderpool site.

\section{Glass Beads}

A large number of small (less than $3 \mathrm{~mm}$ in diameter) drawn glass beads of European manufacture were among the Burial 3 funerary offerings. These include 782 white beads, 34 blue beads, and 48 red Cornaline d'Aleppo beads with dark gray interiors (Figure 29).

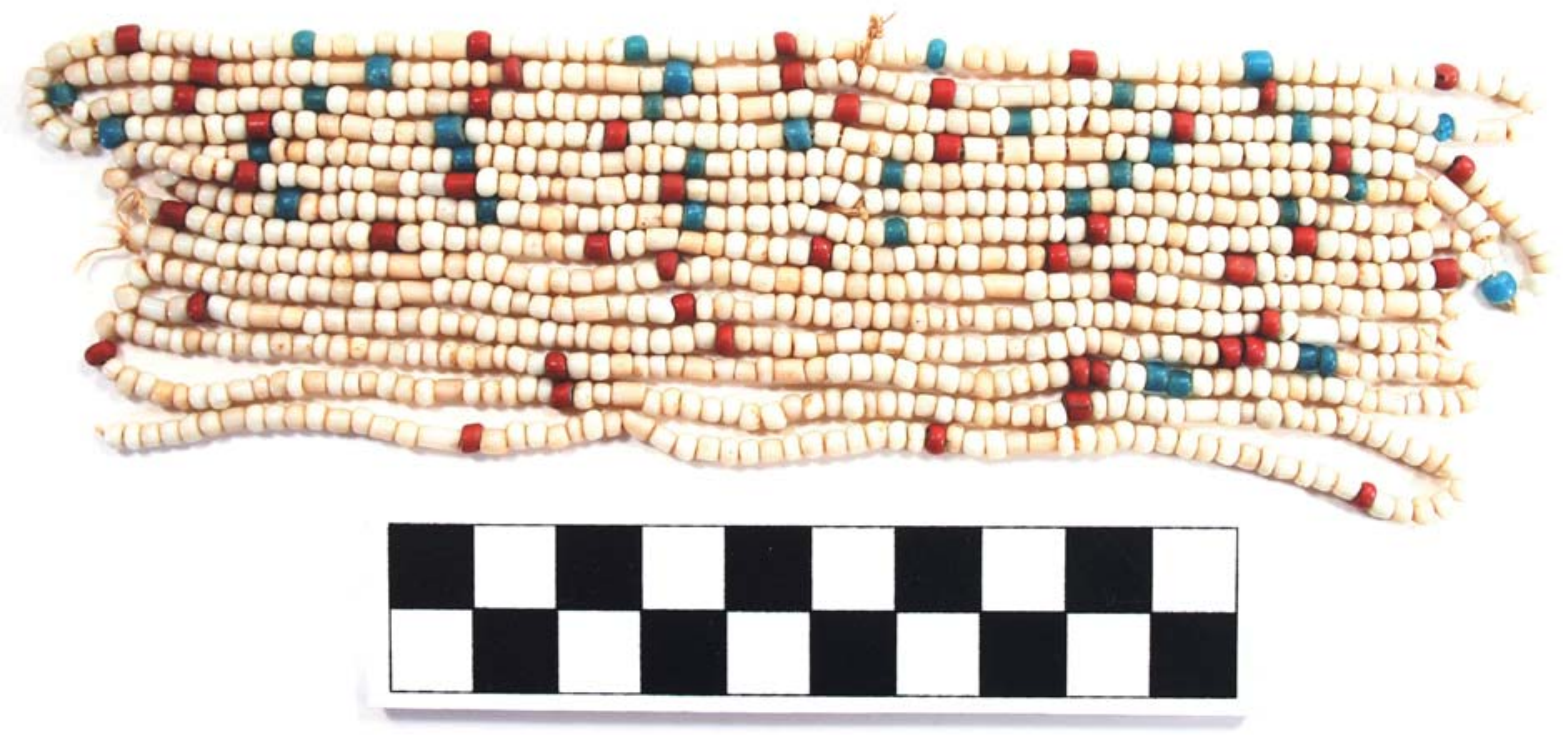

Figure 29. Glass beads from Burial 3 at the Vanderpool site. 


\section{Arrow point}

Also accompanying Burial 3 is a straight-stemmed arrow point made from a local heat-treated quartzite. The blade is lightly serrated, and the barbs are squared and prominent (Figure 30).
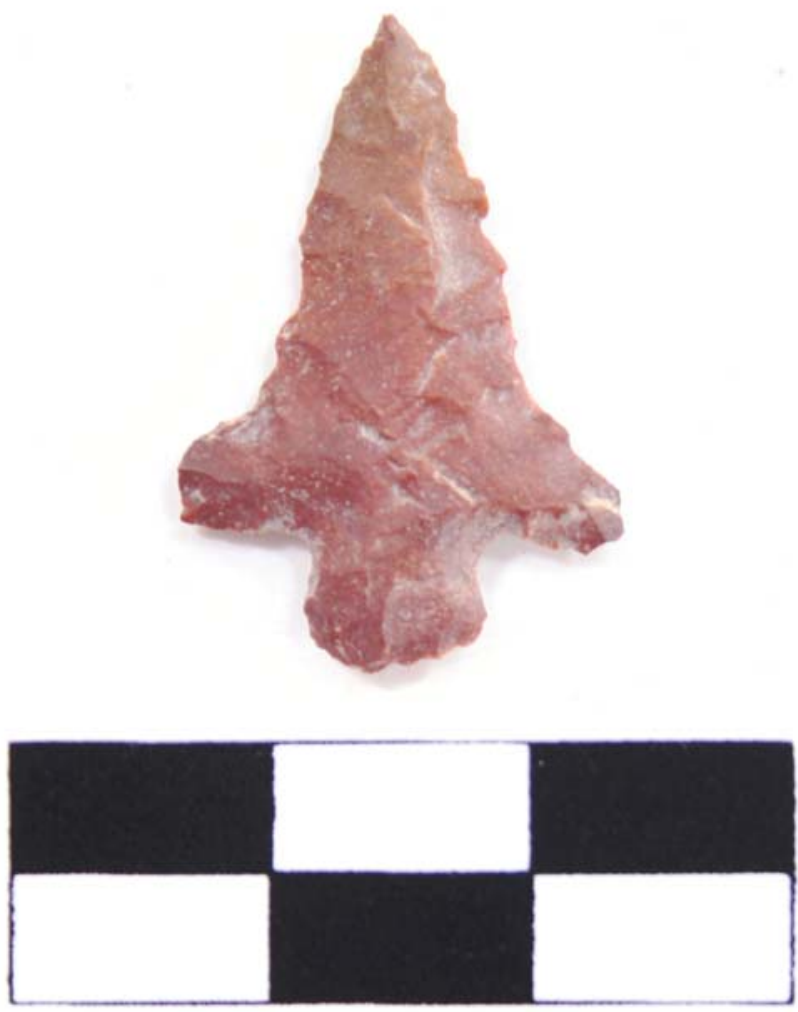

Figure 30. Straight-stemmed arrow point from Burial 3 at the Vanderpool site.

\section{Burial 4}

There is very little information available about Burial 4 in the Jones' notes. This essentially only includes a rough plan map showing its location parallel to Burial 3, with the same east-west orientation, and an accompanying sketch showing the placement of the 12 vessels in the grave. The vessels were placed along what would have been the right side of the body along the leg, in the body mid-section, and around the shoulders, and what would have been the left side of the head. The drawing does not indicate which vessel is which in the grave.

Eleven of the 12 ceramic vessels inventoried for Burial 4 in the Jones burial pottery catalogue remain in the Vanderpool site collection at the Gregg County Historical Museum. The one missing vessel is FIN S17, described as an effigy vessel. 
VESSEL NO.: 2003.08.338 (FIN 18)

NON-PLASTICS AND PASTE: grog

VESSEL FORM: Bottle with a carinated body (Figure 31)

RIM AND LIP FORM: Direct rim and rounded lip

CORE COLOR: B (fired and cooled in a reducing environment)

INTERIOR SURFACE COLOR: dark brown

EXTERIOR SURFACE COLOR: dark brown; fire clouds on the lower neck, body, and base

WALL THICKNESS (RIM, BODY, AND BASE IN MM): rim, $6.1 \mathrm{~mm}$

INTERIOR SURFACE TREATMENT: none

EXTERIOR SURFACE TREATMENT: burnished

HEIGHT (IN CM): 19.3

ORIFICE DIAMETER (IN CM): 4.8

DIAMETER AT BOTTOM OF RIM OR NECK (IN CM): 5.2; maximum body width of $15.2 \mathrm{~cm}$

BASE DIAMETER (IN CM) AND SHAPE OF BASE: 7.0; flat and circular

ESTIMATED VOLUME (IN LITERS): 0.54

DECORATION (INCLUDING MOTIF AND ELEMENTS WHEN APPARENT): The lower neck of the bottle has a single horizontal engraved line with small open pendant triangles. The vessel body has oval-shaped areas repeated four times around the body; the ovals are on both sides of the body carination. Each oval has

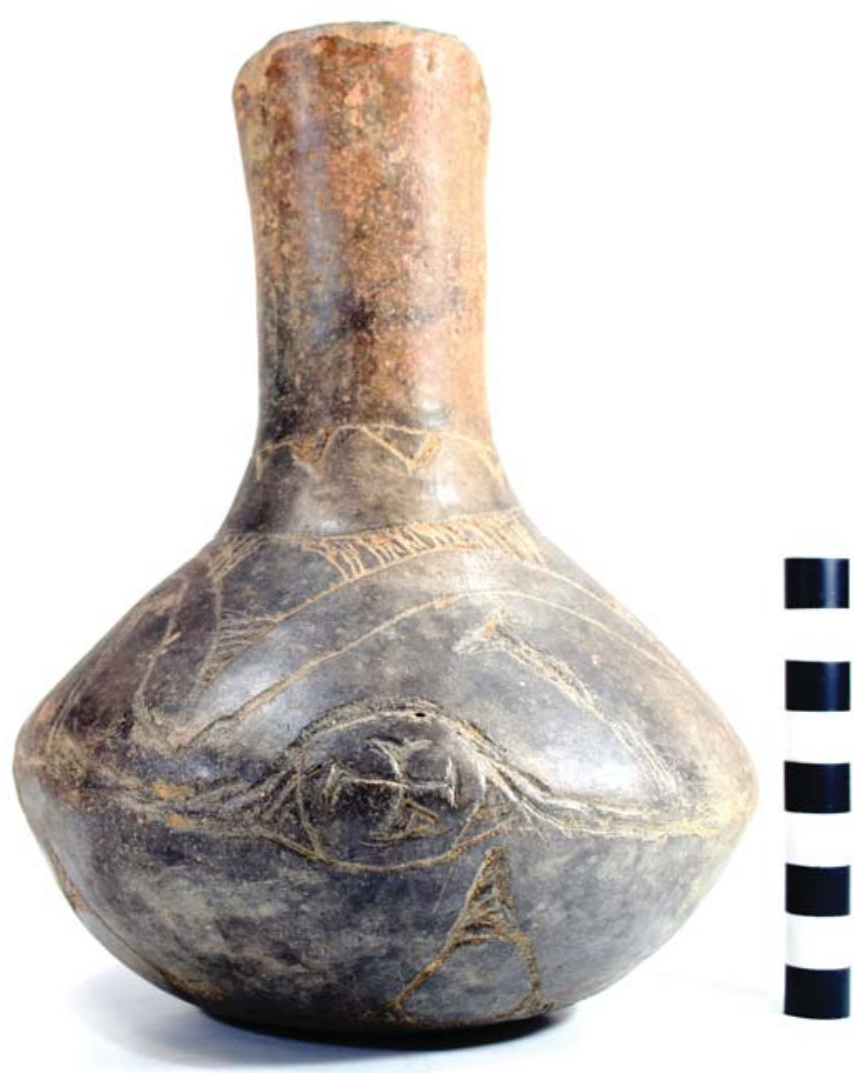

Figure 31. Engraved bottle from Burial 4 at the Vanderpool site. a central circle with crossed-lines and excised triangular ends; there is a single hatched triangle pendant to one side of this central circle element. To the sides and at the top and bottom of each oval are large triangle elements with negative ovals outlined by hatching at the corners of each triangle (Figure 31).

PIGMENT USE AND LOCATION ON VESSEL: none

TYPE AND VARIETY [IF KNOWN]: Unidentified fine ware 
VESSEL NO.: 2003.08.752 (FIN S19)

NON-PLASTICS AND PASTE: grog and hematite

VESSEL FORM: Carinated bowl

RIM AND LIP FORM: Inverted rim and rounded lip

CORE COLOR: F (fired in a reducing environment and cooled in the open air)

INTERIOR SURFACE COLOR: reddish-brown; fire clouds on the body and base

EXTERIOR SURFACE COLOR: reddish-brown to brown

WALL THICKNESS (RIM, BODY, AND BASE IN MM): rim, $6.7 \mathrm{~mm}$

INTERIOR SURFACE TREATMENT: smoothed on the rim

EXTERIOR SURFACE TREATMENT: burnished

HEIGHT (IN CM): 16.3

ORIFICE DIAMETER (IN CM): 21.0

DIAMETER AT BOTTOM OF RIM OR NECK (IN CM): 22.0

BASE DIAMETER (IN CM) AND SHAPE OF BASE: 9.5; flat and circular

ESTIMATED VOLUME (IN LITERS): 3.1

DECORATION (INCLUDING MOTIF AND ELEMENTS WHEN APPARENT):

The rim of the vessel is plain, but the body has vertical to diagonal brushing marks covering its surface (Figure 32).

PIGMENT USE AND LOCATION ON VESSEL: none

TYPE AND VARIETY [IF KNOWN]:

Poynor Brushed

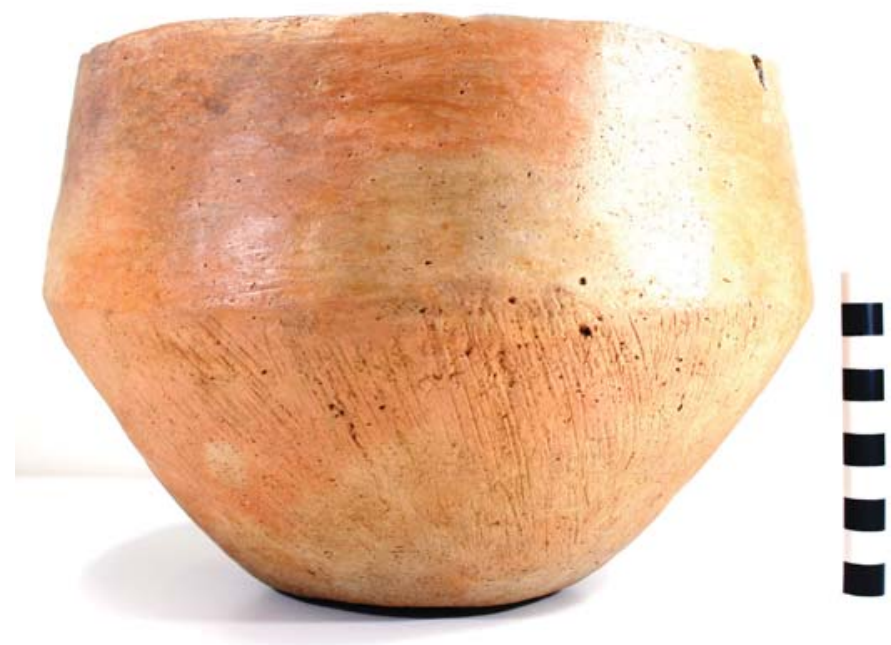

Figure 32. Poynor Brushed carinated bowl, Burial 4 at the Vanderpool site. 
VESSEL NO.: 2003.08.445 (FIN S20)

NON-PLASTICS AND PASTE: bone and hematite

VESSEL FORM: Carinated bowl

RIM AND LIP FORM: Direct rim and rounded lip

CORE COLOR: $\mathrm{F}$ (fired in a reducing environment and cooled in the open air)

INTERIOR SURFACE COLOR: reddish-brown

EXTERIOR SURFACE COLOR: reddish-brown; fire clouds on the body and base

WALL THICKNESS (RIM, BODY, AND BASE IN MM): rim, $6.2 \mathrm{~mm}$

INTERIOR SURFACE TREATMENT: burnished on the rim, otherwise smoothed

EXTERIOR SURFACE TREATMENT: burnished

HEIGHT (IN CM): 9.5

ORIFICE DIAMETER (IN CM): 15.4

DIAMETER AT BOTTOM OF RIM OR NECK (IN CM): 15.5

BASE DIAMETER (IN CM) AND SHAPE OF BASE: 7.6; circular and flat

ESTIMATED VOLUME (IN LITERS): 0.88

DECORATION (INCLUDING MOTIF

AND ELEMENTS WHEN APPARENT):

The rim panel is divided into six ovals by wide vertical hatched brackets, as well as by upper and lower single horizontal engraved lines. The upper and lower parts of each oval has small hatched or excised pendant triangles (Figure 33).

PIGMENT USE AND LOCATION ON VESSEL: white pigment rubbed in the engraved lines

TYPE AND VARIETY [IF KNOWN]:

Poynor Engraved, var. Freeman

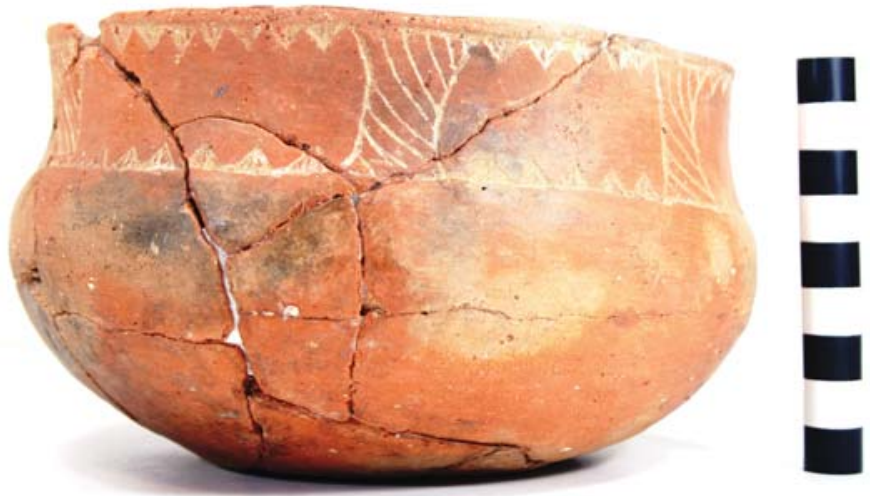

Figure 33. Poynor Engraved, var. Freeman carinated bowl from Burial 4 at the Vanderpool site. 
VESSEL NO.: 2003.08.701 (FIN S21)

NON-PLASTICS AND PASTE: grog

VESSEL FORM: Carinated bowl

RIM AND LIP FORM: Direct rim and a rounded lip

CORE COLOR: A (fired and cooled in an oxidizing environment)

INTERIOR SURFACE COLOR: light yellowish-brown

EXTERIOR SURFACE COLOR: reddish-brown; fire cloud on the base

WALL THICKNESS (RIM, BODY, AND BASE IN MM): rim, $5.8 \mathrm{~mm}$

INTERIOR SURFACE TREATMENT: smoothed on the rim

EXTERIOR SURFACE TREATMENT: burnished

HEIGHT (IN CM): 8.9

ORIFICE DIAMETER (IN CM): 19.7

DIAMETER AT BOTTOM OF RIM OR NECK (IN CM): 19.6

BASE DIAMETER (IN CM) AND SHAPE OF BASE: 7.6; circular and flat

ESTIMATED VOLUME (IN LITERS): 1.1

DECORATION (INCLUDING MOTIF AND ELEMENTS WHEN APPARENT):

The rim panel has an engraved continuous scroll motif that is repeated four times around the vessel. The upper and lower scroll fill zones have a series of vertical engraved lines as well as small concentric oval elements at opposite ends of the fill zones (Figure 34).

PIGMENT USE AND LOCATION ON VESSEL: none

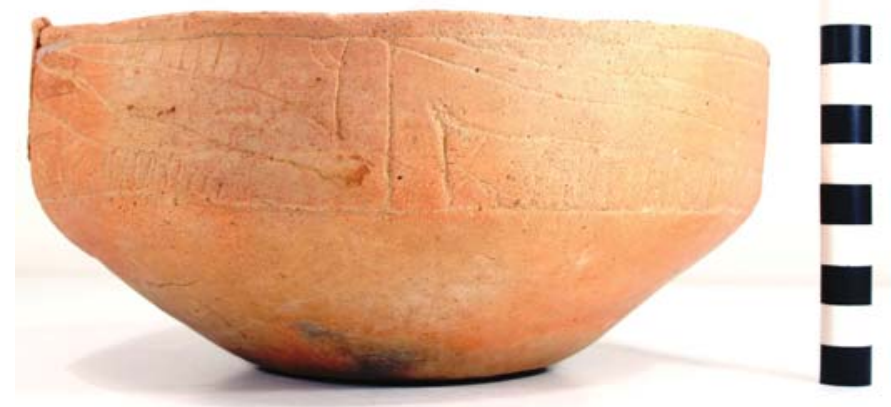

Figure 34. cf. Poynor Engraved, Var. I carinated bowl from Burial 4 at the Vanderpool site.

TYPE AND VARIETY [IF KNOWN]: cf. Poynor Engraved, Var. I 
VESSEL NO.: 2003.08.1852 (FIN S22)

NON-PLASTICS AND PASTE: grog and hematite

VESSEL FORM: Bottle

RIM AND LIP FORM: N/A

CORE COLOR: B (fired and cooled in a reducing environment)

INTERIOR SURFACE COLOR: grayish-brown

EXTERIOR SURFACE COLOR: dark grayish-brown

WALL THICKNESS (RIM, BODY, AND BASE IN MM): body, $5.8 \mathrm{~mm}$

INTERIOR SURFACE TREATMENT: none

EXTERIOR SURFACE TREATMENT: smoothed

HEIGHT (IN CM): N/A

ORIFICE DIAMETER (IN CM): N/A

DIAMETER AT BOTTOM OF RIM OR

NECK (IN CM): maximum body diameter, $7.7 \mathrm{~cm}$

BASE DIAMETER (IN CM) AND SHAPE

OF BASE: 5.5; circular and flat

ESTIMATED VOLUME (IN LITERS):

N/A

DECORATION (INCLUDING MOTIF

AND ELEMENTS WHEN APPARENT):

The vessel body has sets of engraved concentric ovals and inner circles repeated three times around the vessel (Figure 35).

PIGMENT USE AND LOCATION ON VESSEL: white pigment rubbed in the engraved lines

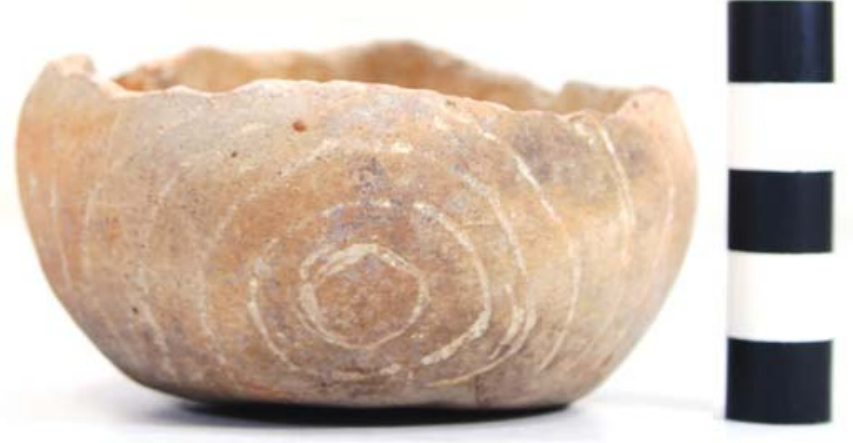

Figure 35. cf. Poynor Engraved, Var. $S$ bottle from Burial 4 at the Vanderpool site.

TYPE AND VARIETY [IF KNOWN]: cf. Poynor Engraved, Var. S 
VESSEL NO.: 2003.08.788 (FIN S23)

NON-PLASTICS AND PASTE: grog-hematite-organics

VESSEL FORM: Carinated bowl

RIM AND LIP FORM: Direct rim and a rounded lip

CORE COLOR: $\mathrm{F}$ (fired in a reducing environment and cooled in the open air)

INTERIOR SURFACE COLOR: reddish-brown

EXTERIOR SURFACE COLOR: reddish-brown; fire clouds on the rim, body, and base

WALL THICKNESS (RIM, BODY, AND BASE IN MM): rim, $6.7 \mathrm{~mm}$

INTERIOR SURFACE TREATMENT: burnished on the rim, otherwise smoothed

EXTERIOR SURFACE TREATMENT: burnished

HEIGHT (IN CM): 12.7

ORIFICE DIAMETER (IN CM): 18.9

DIAMETER AT BOTTOM OF RIM OR NECK (IN CM): 18.6

BASE DIAMETER (IN CM) AND SHAPE OF BASE: 8.9; circular and flat

ESTIMATED VOLUME (IN LITERS): 2.1

DECORATION (INCLUDING MOTIF AND ELEMENTS WHEN APPARENT): The rim is divided into 11 oval-shaped panels by crosshatched engraved vertical brackets and single upper and lower horizontal engraved lines (Figure 36).

PIGMENT USE AND LOCATION ON VESSEL: none

TYPE AND VARIETY [IF KNOWN]: Poynor Engraved, var. Hood

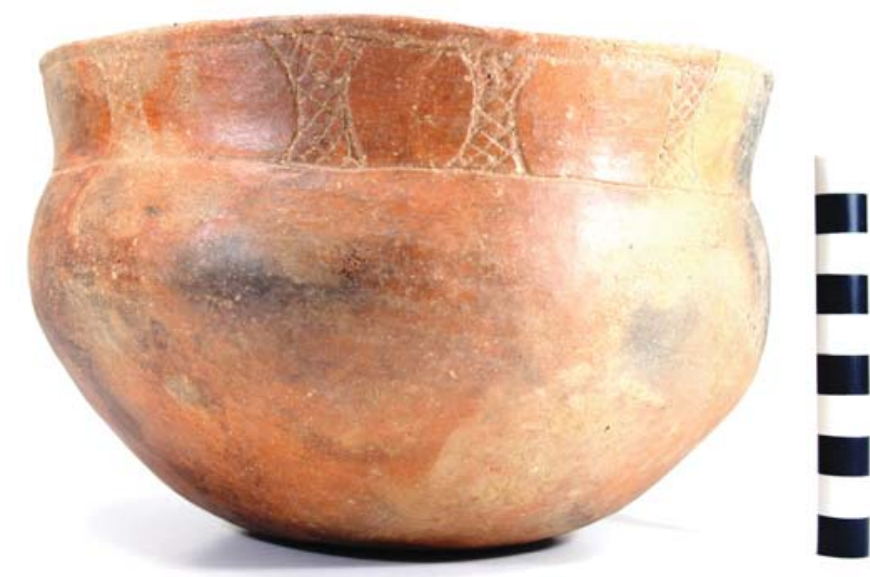

Figure 36. Poynor Engraved, var. Hood carinated bowl, Burial 4 at the Vanderpool site. 
VESSEL NO.: 2003.08.0006 (FIN S24)

NON-PLASTICS AND PASTE: bone and hematite

VESSEL FORM: Carinated bowl

RIM AND LIP FORM: Direct rim and a flat lip

CORE COLOR: A (fired and cooled in an oxidizing environment)

INTERIOR SURFACE COLOR: yellowish-brown

EXTERIOR SURFACE COLOR: yellowish-brown

WALL THICKNESS (RIM, BODY, AND BASE IN MM): rim, $5.5 \mathrm{~mm}$

INTERIOR SURFACE TREATMENT: burnished on the rim, otherwise smoothed

EXTERIOR SURFACE TREATMENT: burnished

HEIGHT (IN CM): 14.2

ORIFICE DIAMETER (IN CM): 19.2

DIAMETER AT BOTTOM OF RIM OR NECK (IN CM): 19.0

BASE DIAMETER (IN CM) AND SHAPE OF BASE: 10.2; circular and flat

ESTIMATED VOLUME (IN LITERS):

2.4

DECORATION (INCLUDING MOTIF

AND ELEMENTS WHEN APPARENT):

The rim is divided into six oval-shaped panels by engraved brackets filled with vertical arcing lines as well as single upper and lower horizontal engraved lines (Figure 37).

PIGMENT USE AND LOCATION ON VESSEL: none

TYPE AND VARIETY [IF KNOWN]:

Poynor Engraved, var. Hood

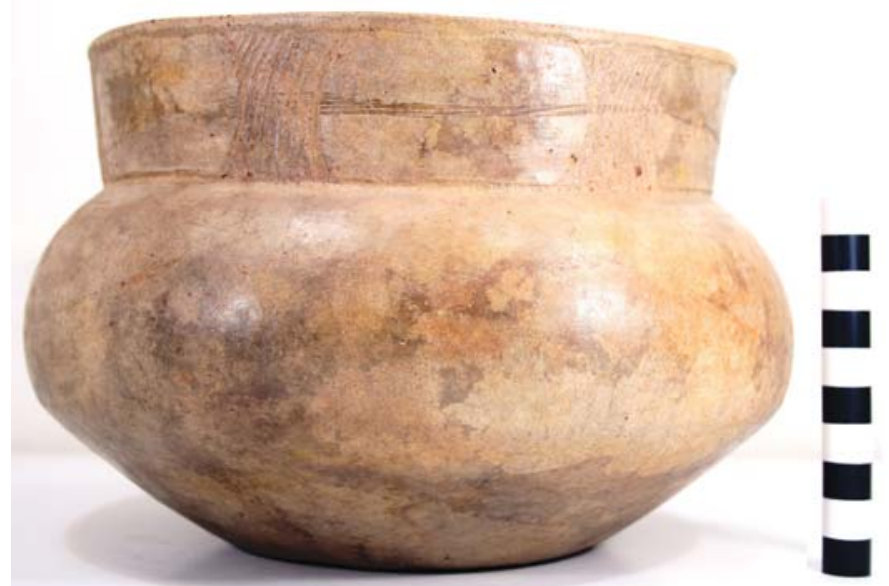

Figure 37. Poynor Engraved, var. Hood carinated bowl from Burial 4 at the Vanderpool site. 
VESSEL NO.: 2003.08.0881 (FIN S25)

NON-PLASTICS AND PASTE: grog

VESSEL FORM: Jar

RIM AND LIP FORM: Everted rim and rounded lip

CORE COLOR: F (fired in a reducing environment and cooled in the open air)

INTERIOR SURFACE COLOR: yellowish-brown; fire clouds on the rim and body

EXTERIOR SURFACE COLOR: yellowish-brown; fire clouds on the rim, body, and base; organic residue on the rim and body

WALL THICKNESS (RIM, BODY, AND BASE IN MM): rim, $7.1 \mathrm{~mm}$

INTERIOR SURFACE TREATMENT: smoothed on the rim

EXTERIOR SURFACE TREATMENT: none

HEIGHT (IN CM): 15.8

ORIFICE DIAMETER (IN CM): 16.5

DIAMETER AT BOTTOM OF RIM OR NECK (IN CM): 14.3

BASE DIAMETER (IN CM) AND SHAPE OF BASE: 6.5 ; circular and flat

ESTIMATED VOLUME (IN LITERS): 1.6

DECORATION (INCLUDING MOTIF AND ELEMENTS WHEN APPARENT): The rim has three $\mathrm{X}$-shaped appliqued lugs, each 23 $\mathrm{mm}$ in length. The vessel body has three widely-spaced vertical rows of pinching from the rim-body juncture to $2 \mathrm{~cm}$ above the base (Figure 38).

\section{PIGMENT USE AND LOCATION ON}

VESSEL: none

TYPE AND VARIETY [IF KNOWN]:

Unidentified utility ware

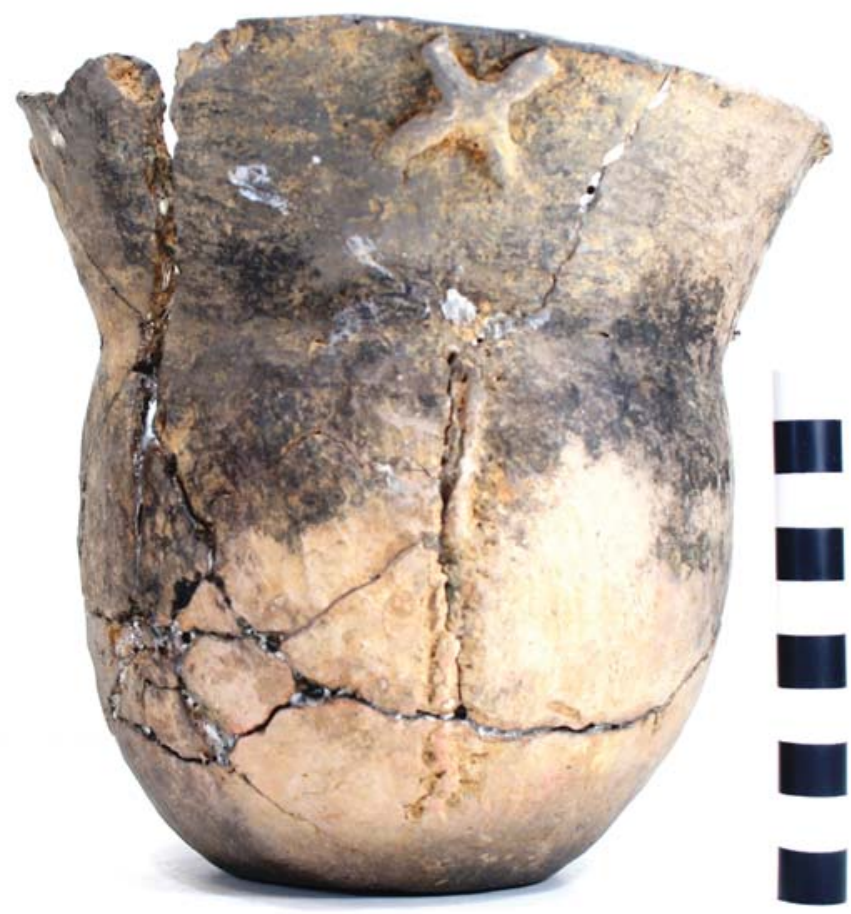

Figure 38. Appliqued-pinched jar, Burial 4 at the Vanderpool site. 
VESSEL NO.: 2003.08.654 (FIN S26)

NON-PLASTICS AND PASTE: grog and hematite

VESSEL FORM: Bowl

RIM AND LIP FORM: Direct rim and rounded lip

CORE COLOR: A (fired and cooled in an oxidizing environment)

INTERIOR SURFACE COLOR: yellowish-brown; fire clouds on the rim, body, and base

EXTERIOR SURFACE COLOR: yellowish-brown; fire clouds on the base

WALL THICKNESS (RIM, BODY, AND BASE IN MM): rim, 9.0 mm

INTERIOR SURFACE TREATMENT: smoothed

EXTERIOR SURFACE TREATMENT: smoothed

HEIGHT (IN CM): 17.7

ORIFICE DIAMETER (IN CM): 31.2

DIAMETER AT BOTTOM OF RIM OR NECK (IN CM): N/A

BASE DIAMETER (IN CM) AND SHAPE

OF BASE: 9.5; circular and flat

ESTIMATED VOLUME (IN LITERS): 4.4

DECORATION (INCLUDING MOTIF

AND ELEMENTS WHEN APPARENT):

Plain (Figure 39)

PIGMENT USE AND LOCATION ON

VESSEL: none

TYPE AND VARIETY [IF KNOWN]:

Unidentified plain ware

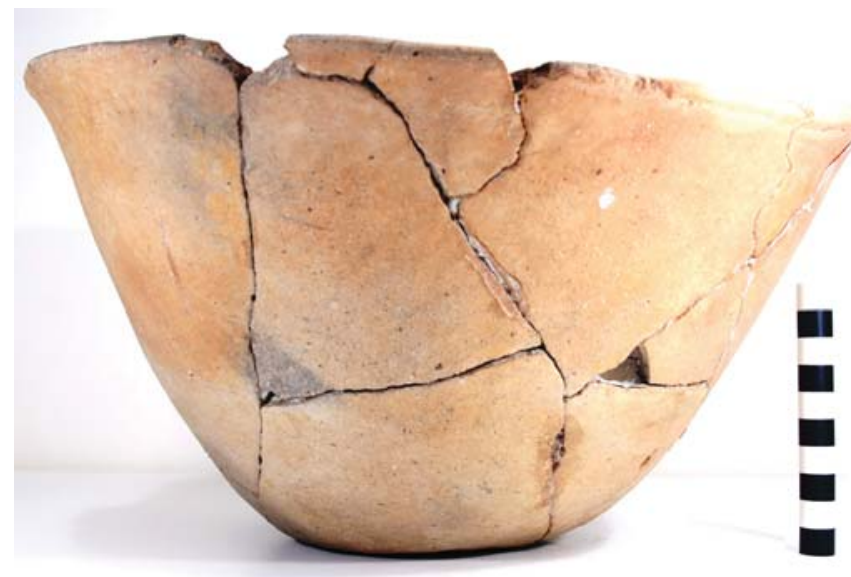

Figure 39. Plain bowl, Burial 4 at the Vanderpool site. 
VESSEL NO.: 2003.08.1794 (FIN S27)

NON-PLASTICS AND PASTE: grog and hematite

VESSEL FORM: Jar

RIM AND LIP FORM: Everted rim and a rounded lip

CORE COLOR: F (fired in a reducing environment and cooled in the open air)

INTERIOR SURFACE COLOR: reddish-brown; fire clouds on the rim and base

EXTERIOR SURFACE COLOR: reddish-brown; fire clouds on the rim; organic residue on the rim and body

WALL THICKNESS (RIM, BODY, AND BASE IN MM): rim, $6.5 \mathrm{~mm}$

INTERIOR SURFACE TREATMENT: smoothed on the rim

EXTERIOR SURFACE TREATMENT: burnished

HEIGHT (IN CM): 11.5

ORIFICE DIAMETER (IN CM): 16.5

DIAMETER AT BOTTOM OF RIM OR NECK (IN CM): 15.6

BASE DIAMETER (IN CM) AND SHAPE OF BASE: 7.5; circular and flat

ESTIMATED VOLUME (IN LITERS):

1.1

DECORATION (INCLUDING MOTIF AND ELEMENTS WHEN APPARENT):

The rim is divided into six panels by sets of vertically arcing engraved brackets and single upper and lower horizontal engraved lines (Figure 40).

\section{PIGMENT USE AND LOCATION ON}

VESSEL: none

TYPE AND VARIETY [IF KNOWN]:

Poynor Engraved, var. Hood

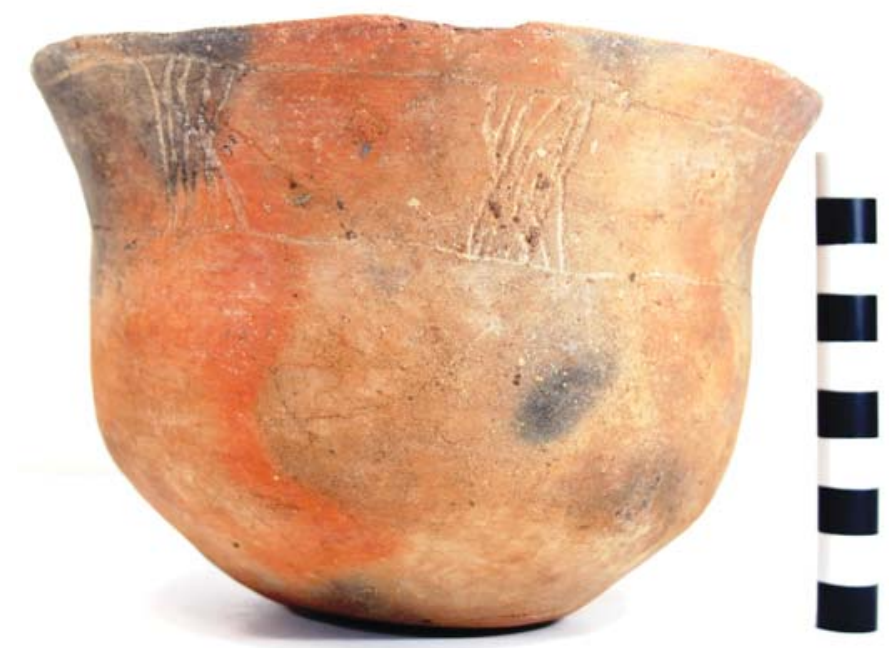

Figure 40. Poynor Engraved, var. Hood jar, Burial 4 at the Vanderpool site. 
VESSEL NO.: 2003.08.317 (FIN S28)

NON-PLASTICS AND PASTE: grog and hematite

VESSEL FORM: Jar

RIM AND LIP FORM: Everted rim and rounded lip

CORE COLOR: F (fired in a reducing environment and cooled in the open air)

INTERIOR SURFACE COLOR: light reddish-brown; fire clouds on the body and base

EXTERIOR SURFACE COLOR: light reddish-brown; fire clouds on the rim, body, and base; organic residue on the rim

WALL THICKNESS (RIM, BODY, AND BASE IN MM): rim, 7.6 mm; body, 6.9 mm

INTERIOR SURFACE TREATMENT: smoothed

EXTERIOR SURFACE TREATMENT: none

HEIGHT (IN CM): 22.0

ORIFICE DIAMETER (IN CM): 21.0

DIAMETER AT BOTTOM OF RIM OR

NECK (IN CM): 20.0

BASE DIAMETER (IN CM) AND SHAPE

OF BASE: 7.5; circular and flat

ESTIMATED VOLUME (IN LITERS): 4.2

DECORATION (INCLUDING MOTIF

AND ELEMENTS WHEN APPARENT):

The rim has horizontal brushing marks over which 11 incised nested triangle elements have been superimposed. The vessel body has diagonal brushing marks from the rimbody juncture to the base (Figure 41).

PIGMENT USE AND LOCATION ON VESSEL: none

TYPE AND VARIETY [IF KNOWN]:

Unidentified utility ware, possibly

Maydelle Incised

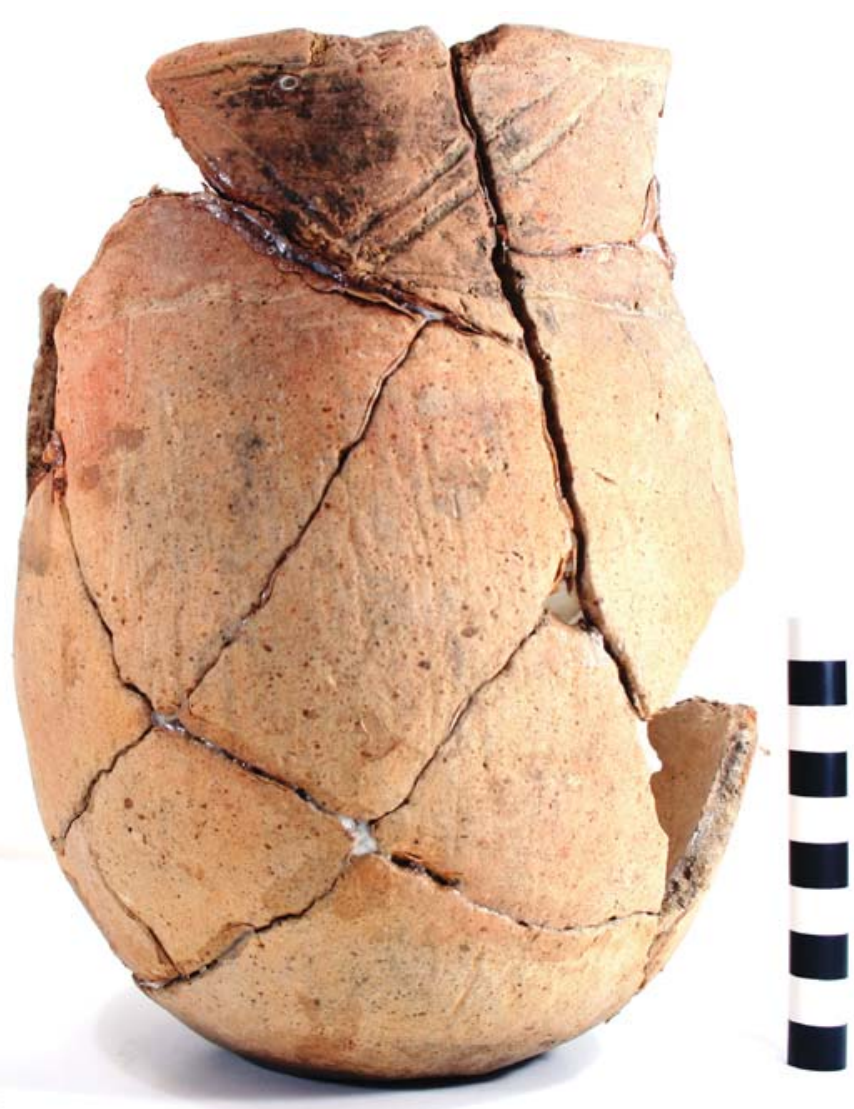

Figure 41. Brushed-incised jar from Burial 4 at the Vanderpool site. 


\section{Burial 5}

Burial 5 was that of an adult individual placed on their back in an extended supine position, likely facing west (Figure 42), with the pit extending into the red clay B-horizon; portions of the cranium and long bones were preserved in the grave. There were six ceramic vessels placed in the grave as funerary offerings, most along the right side of the body from the head to the lower right foot, and one large carinated bowl had been placed by the left foot. Other funerary offerings included in Burial 5-although not identified in the Gregg County Historical Museum collections from the Vanderpool site-include a large chipped biface by the upper left arm, and two Perdiz arrow points (Figure 42).

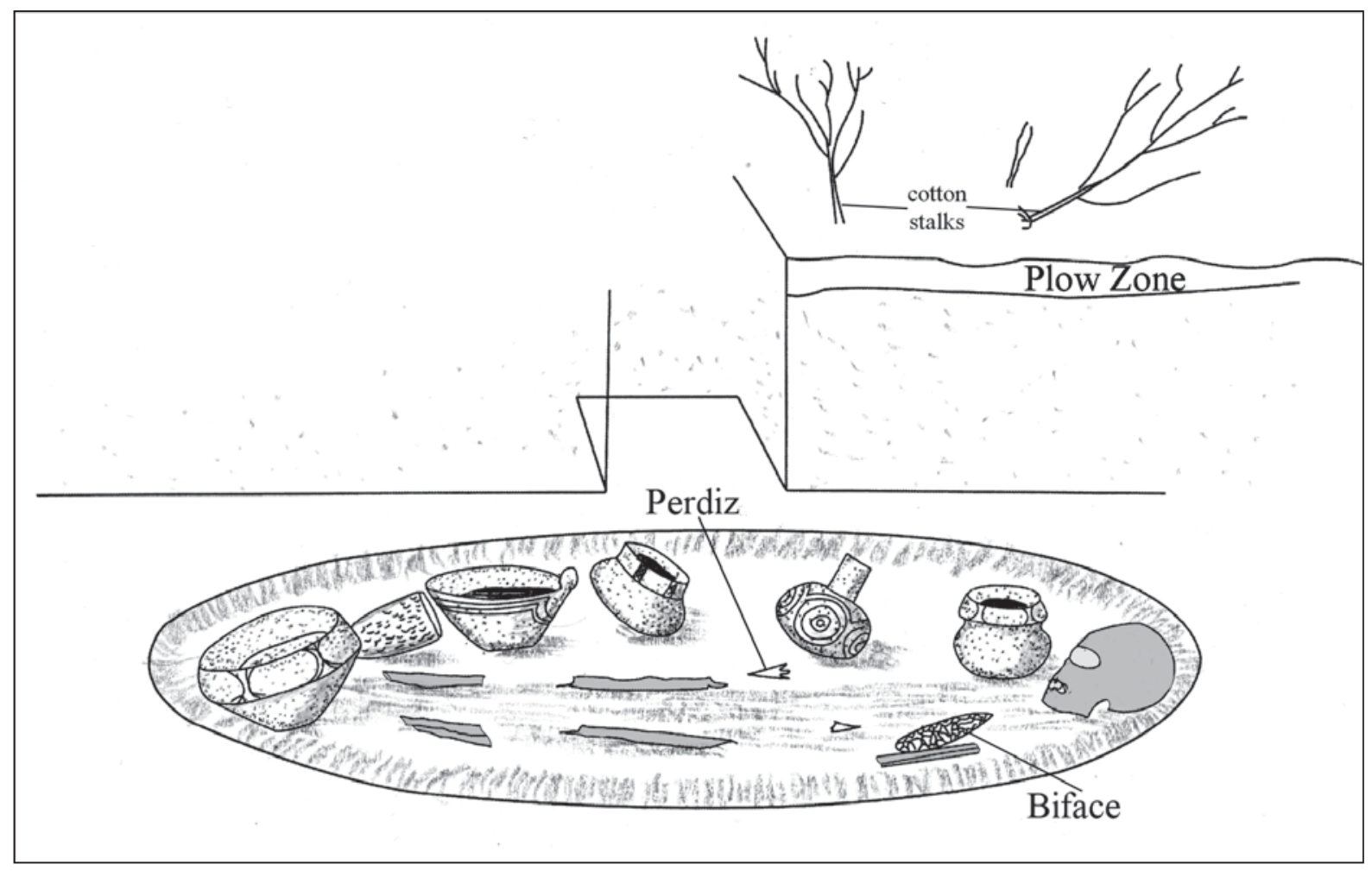

Figure 42. Plan map of Burial 5 at the Vanderpool site.

VESSEL NO.: 2003.08.757 (FIN S29)

NON-PLASTICS AND PASTE: grog and hematite

VESSEL FORM: Bottle

RIM AND LIP FORM: Direct rim and a flat lip

CORE COLOR: F (fired in a reducing environment and cooled in the open air)

INTERIOR SURFACE COLOR: dark yellowish-brown

EXTERIOR SURFACE COLOR: dark yellowish-brown; fire clouds on the body

WALL THICKNESS (RIM, BODY, AND BASE IN MM): rim, $6.4 \mathrm{~mm}$; body, $6.6 \mathrm{~mm}$; base, $8.4 \mathrm{~mm}$ 
INTERIOR SURFACE TREATMENT: none

EXTERIOR SURFACE TREATMENT: smoothed

HEIGHT (IN CM): N/A

ORIFICE DIAMETER (IN CM): 5.0

DIAMETER AT BOTTOM OF RIM OR NECK (IN CM): N/A

BASE DIAMETER (IN CM) AND

SHAPE OF BASE: 8.9 ; circular and flat

ESTIMATED VOLUME (IN LITERS): N/A

DECORATION (INCLUDING MOTIF AND ELEMENTS WHEN APPARENT): The vessel body has four repeated sets of concentric engraved ovals with a small central circle (Figure 43).

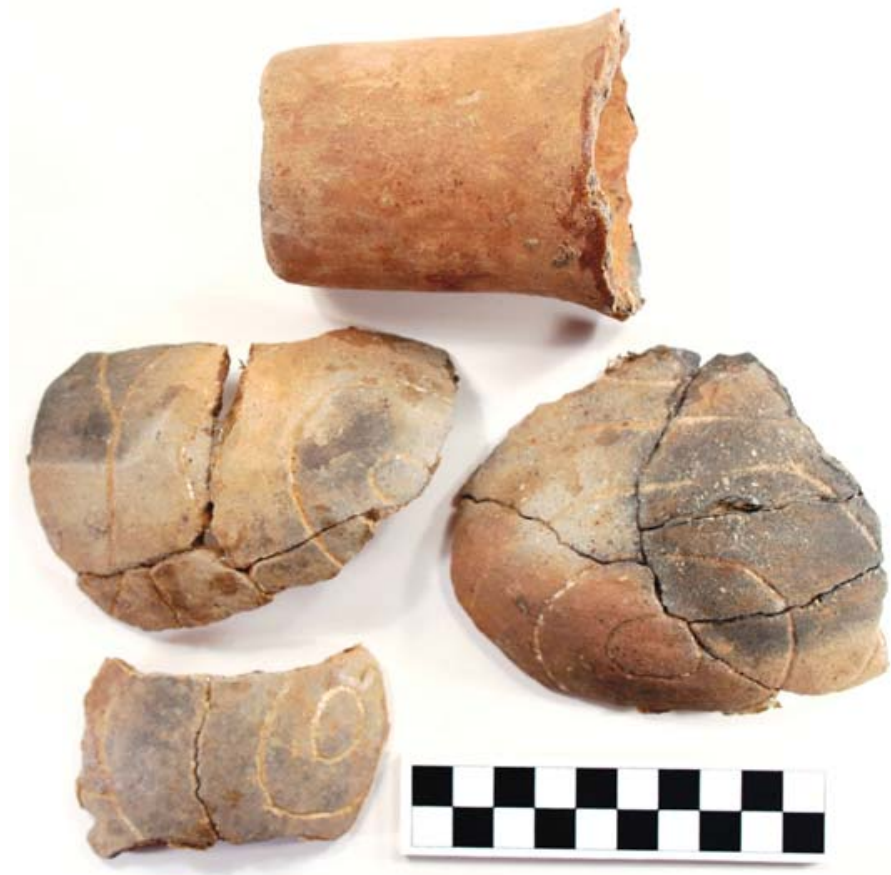

Figure 43. Sherds from Poynor Engraved, Var. $S$ bottle, Burial 5 at the Vanderpool site.

PIGMENT USE AND LOCATION ON VESSEL: white pigment in the engraved lines

TYPE AND VARIETY [IF KNOWN]: Poynor Engraved, Var. $S$

VESSEL NO.: 2003.08.730 (FIN S30)

NON-PLASTICS AND PASTE: grog

VESSEL FORM: Carinated bowl

RIM AND LIP FORM: Direct rim and a rounded lip

CORE COLOR: $\mathrm{F}$ (fired in a reducing environment and cooled in the open air)

INTERIOR SURFACE COLOR: reddish-brown

EXTERIOR SURFACE COLOR: reddish-brown; fire clouds on the body and base

WALL THICKNESS (RIM, BODY, AND BASE IN MM): rim, 5.6 mm

INTERIOR SURFACE TREATMENT: burnished on the rim, otherwise smoothed EXTERIOR SURFACE TREATMENT: burnished

HEIGHT (IN CM): 11.9 
ORIFICE DIAMETER (IN CM): 18.1

DIAMETER AT BOTTOM OF RIM OR NECK (IN CM): 18.3

BASE DIAMETER (IN CM) AND SHAPE OF BASE: 9.0; circular and flat

ESTIMATED VOLUME (IN LITERS): 1.3

DECORATION (INCLUDING MOTIF AND ELEMENTS WHEN APPARENT): The rim is divided into seven rectangular panels by a series of vertical columns with hatched lines as well as single upper and lower horizontal engraved lines (Figure 44).

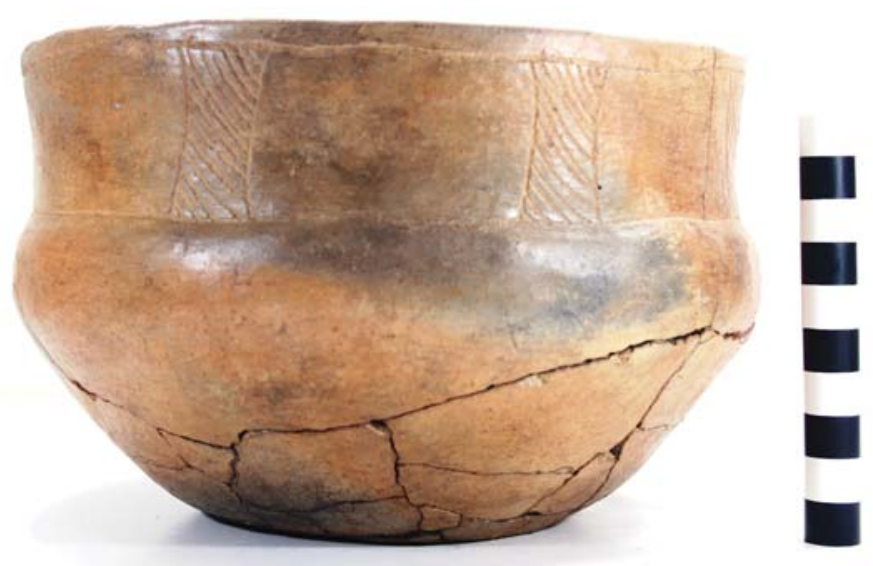

Figure 44. Poynor Engraved, cf. Var. D carinated bowl from Burial 5 at the Vanderpool site.

PIGMENT USE AND LOCATION ON VESSEL: none

TYPE AND VARIETY [IF KNOWN]: Poynor Engraved, cf. Var. D

VESSEL NO.: 2003.08.0008 (FIN S31)

NON-PLASTICS AND PASTE: grog

VESSEL FORM: Conjoined carinated bowls (Figure 45)

RIM AND LIP FORM: Inverted rim and rounded lip

CORE COLOR: F (fired in a reducing environment and cooled in the open air)

INTERIOR SURFACE COLOR: dark yellowish-brown

EXTERIOR SURFACE COLOR: dark yellowish-brown; fire clouds on the body and base; organic residue patches are present on both vessels

WALL THICKNESS (RIM, BODY, AND BASE IN MM): rim, $6.2 \mathrm{~mm}$

INTERIOR SURFACE TREATMENT: smoothed on upper rim

EXTERIOR SURFACE TREATMENT: burnished

HEIGHT (IN CM): 11.5

ORIFICE DIAMETER (IN CM): 12.1

DIAMETER AT BOTTOM OF RIM OR NECK (IN CM): 13.2 (upper vessel); $13.6 \mathrm{~cm}$ (lower vessel)

BASE DIAMETER (IN CM) AND SHAPE OF BASE: 7.4; circular and flat 
ESTIMATED VOLUME (IN LITERS): 0.83

\section{DECORATION (INCLUDING MOTIF} AND ELEMENTS WHEN APPARENT): The lower conjoined vessel is plain, but the upper conjoined vessel has eight ovalshaped panels defined by sets of curvilinear engraved lines and single upper and lower horizontal engraved lines (Figure 45).

PIGMENT USE AND LOCATION ON VESSEL: white pigment in the engraved lines

TYPE AND VARIETY [IF KNOWN]: Poynor Engraved, var. Cook

VESSEL NO.: 2003.08.1778 (FIN S32)

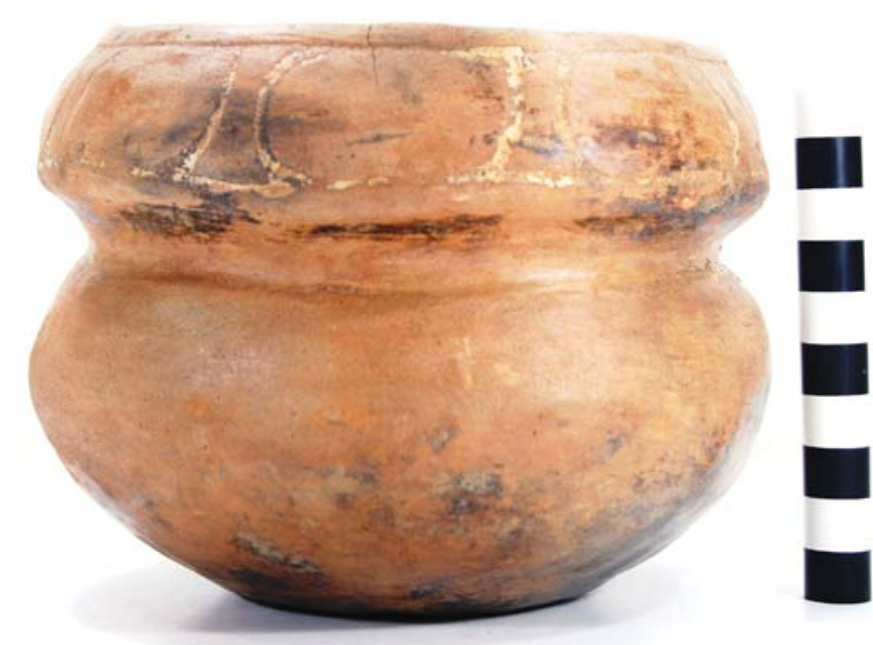

Figure 45. Conjoined Poynor Engraved, var. Cook carinated bowls, Burial 5 at the Vanderpool site.

NON-PLASTICS AND PASTE: grog

VESSEL FORM: Bowl with tab tail (60 x $25 \mathrm{~mm}$ in length and width) and bird/duck effigy head (70 x 35 $\mathrm{mm}$ ) (Figure 46)

RIM AND LIP FORM: Direct rim and rounded lip

CORE COLOR: $\mathrm{F}$ (fired in a reducing environment and cooled in the open air)

INTERIOR SURFACE COLOR: reddish-brown

EXTERIOR SURFACE COLOR: reddish-brown

WALL THICKNESS (RIM, BODY, AND BASE IN MM): rim, 6.9 mm

INTERIOR SURFACE TREATMENT: smoothed

EXTERIOR SURFACE TREATMENT:

burnished

HEIGHT (IN CM): $11.3 ; 13.3 \mathrm{~cm}$ at the top of the effigy head

ORIFICE DIAMETER (IN CM): 22.3

DIAMETER AT BOTTOM OF RIM OR

NECK (IN CM): N/A

BASE DIAMETER (IN CM) AND SHAPE OF BASE: 9.6; circular and flat

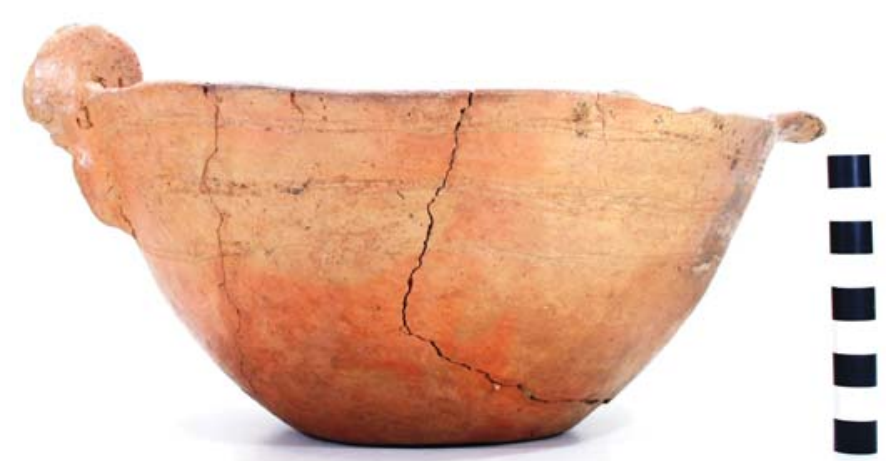

Figure 46. Hood Engraved, var. Hood effigy bowl from Burial 5 at the Vanderpool site. 
ESTIMATED VOLUME (IN LITERS): 1.0

DECORATION (INCLUDING MOTIF AND ELEMENTS WHEN APPARENT): The rim has three double sets of horizontal engraved lines around the vessel (Figure 46).

PIGMENT USE AND LOCATION ON VESSEL: none

TYPE AND VARIETY [IF KNOWN]: Hood Engraved, var. Hood

VESSEL NO.: 2003.08.79 (FIN S33)

NON-PLASTICS AND PASTE: grog

VESSEL FORM: Jar with two appliqued lugs (Figure 47)

RIM AND LIP FORM: Direct rim and rounded lip

CORE COLOR: $\mathrm{F}$ (fired in a reducing environment and cooled in the open air)

INTERIOR SURFACE COLOR: reddish-brown; fire clouds on the rim, body, and base

EXTERIOR SURFACE COLOR: reddish-brown; fire clouds on the rim, body, and base

WALL THICKNESS (RIM, BODY, AND BASE IN MM): rim, 7.6 mm

INTERIOR SURFACE TREATMENT: smoothed

EXTERIOR SURFACE TREATMENT: none

HEIGHT (IN CM): 16.3

ORIFICE DIAMETER (IN CM): 11.4

DIAMETER AT BOTTOM OF RIM OR NECK (IN $\mathrm{CM}): 11.4$

BASE DIAMETER (IN CM) AND SHAPE OF BASE:

7.6; circular and flat

ESTIMATED VOLUME (IN LITERS): 1.7

DECORATION (INCLUDING MOTIF AND

ELEMENTS WHEN APPARENT): There are 15

horizontal rows of tool punctations from the rim to within $15 \mathrm{~mm}$ of the vessel base (Figure 47).

PIGMENT USE AND LOCATION ON VESSEL: none

TYPE AND VARIETY [IF KNOWN]: Unidentified utility ware

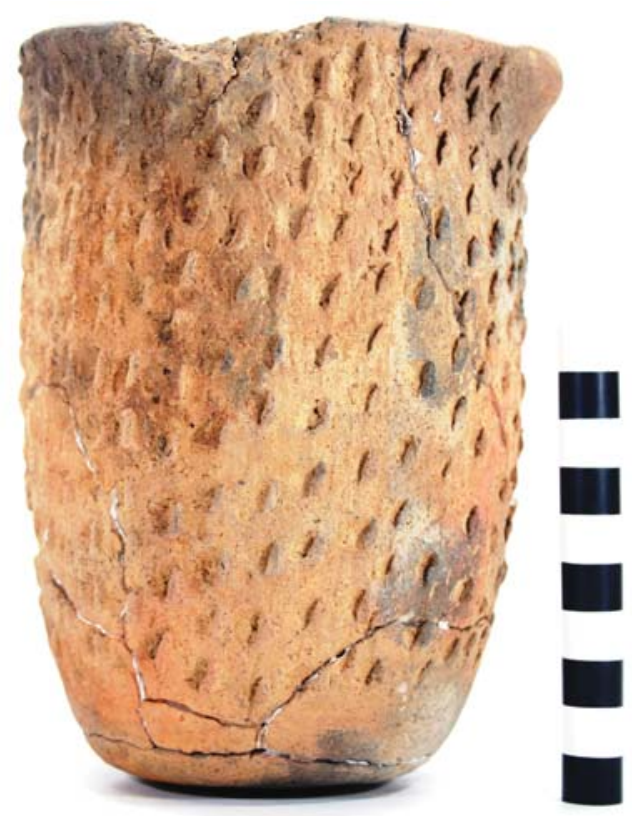

Figure 47. Tool punctated jar, Burial 5 at the Vanderpool site. 
VESSEL NO.: 2003.08.1074 (FIN 34)

NON-PLASTICS AND PASTE: grog

VESSEL FORM: Carinated bowl

RIM AND LIP FORM: Inverted rim and rounded lip

CORE COLOR: A (fired and cooled in an oxidizing environment)

INTERIOR SURFACE COLOR: yellowish-brown; fire clouds on the base

EXTERIOR SURFACE COLOR: yellowish-brown; fire clouds on the base

WALL THICKNESS (RIM, BODY, AND BASE IN MM): rim, 8.4 mm

INTERIOR SURFACE TREATMENT: smoothed

EXTERIOR SURFACE TREATMENT: burnished

HEIGHT (IN CM): 18.8

ORIFICE DIAMETER (IN CM): 27.6

DIAMETER AT BOTTOM OF RIM OR

NECK (IN CM): 29.2

BASE DIAMETER (IN CM) AND

SHAPE OF BASE: 11.5; circular and flat

ESTIMATED VOLUME (IN LITERS): 4.6

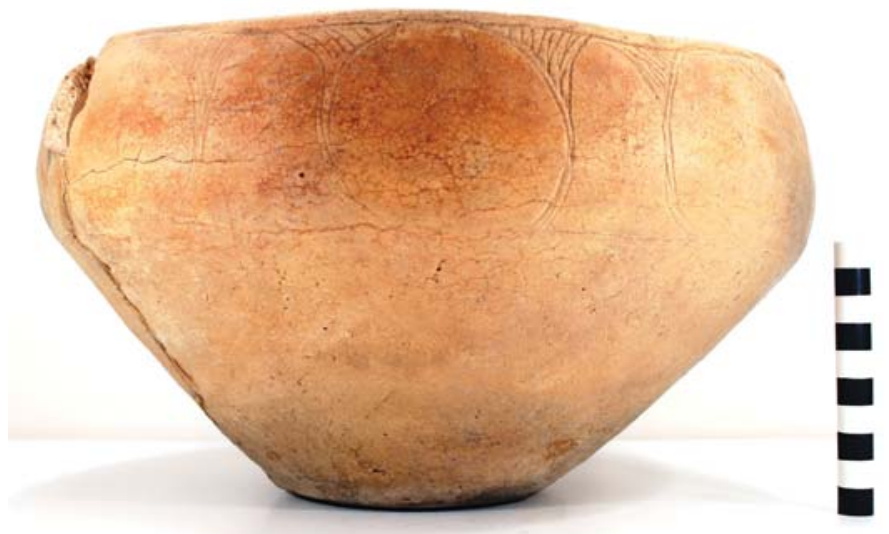

Figure 48. Poynor Engraved, var. Cook carinated bowl from Burial 5 at the Vanderpool site.

DECORATION (INCLUDING MOTIF AND ELEMENTS WHEN APPARENT): The rim is divided into nine semi-circles by sets of vertical curvilinear engraved lines (Figure 48). There are also small hatched triangles attached to both sides of the upper semi-circles (see Perttula 2011:Figure 6-64d).

PIGMENT USE AND LOCATION ON VESSEL: none

TYPE AND VARIETY [IF KNOWN]: Poynor Engraved, var. Cook

When UT archaeologists recorded the site in 1957, they collected a small number of grog and/or bonetempered Caddo sherds there. These included five plain sherds, two with brushed decorative elements, and one sherd with incised decorative elements. In 1969, SMU archaeologists that revisited the site collected 24 sherds: nine plain, 11 brushed, three with incised decorative elements, and one untyped engraved sherd (Anderson 1972:188-189).

Lastly, Selden et al. (2014) completed 3D digital scanning of 27 vessels from the Vanderpool site. A geometric morphometric analysis of the vessels indicates there are three forms of jars, two forms of bottles, two forms of carinated bowls, and four bowl forms (Selden et al. 2014:Figure 10) in the mortuary assemblage. 


\section{$41 S M 78$}

This site is on a terrace east of Saline Creek, and Caddo ceramic sherds were noted in 1957 over a ca. 4.0 acre cultivated field. The few recovered ceramics indicate that $41 \mathrm{SM} 78$ was occupied during the Frankston phase (Johnson 1961:224): two plain sherds, four brushed sherds, and one Killough Pinched sherd. Buddy Jones, L. A. Wallace, and Ray Vanderpool told Johnson about the site.

\section{$41 S M 79$}

According to Johnson (1961:224), this is a large Caddo site, covering 35 acres of a low hill or ridge slope overlooking the floodplain of County Line Creek; this creek is a westward-flowing tributary of Saline Creek. The recovered ceramic sherds $(n=99)$ and one celt fragment, including those from Bullard Brushed $(n=2)$, Maydelle Incised $(n=11)$, and Poynor Engraved $(n=4)$ vessels, indicate that the ancestral Caddo occupation likely took place during the Frankston phase; there were also four sherds with punctated decorative elements. Sam Whiteside had told Johnson about the site. A single unidentified dart point fragment suggests that 41SM79 was also used during either Archaic or Woodland period times.

The collection of artifacts at TARL from the 1957 archaeological survey reported by Johnson (1961) has both lithic and ceramic artifacts. The lithic artifacts associated with the Caddo settlement at 41SM79 are a grayish-green siltstone celt fragment from a Ouachita Mountains/Red River gravels source and a unifacial quartzite Perdiz arrow point. The ceramic assemblage includes plain $(n=70)$, utility $(n=13)$, and fine $(n=8)$ ware sherds. Over 92 percent of the sherds are from grog-tempered vessels; another 5.5 percent are from bonetempered vessels and 2.2 percent are from grog-bone-tempered vessels.

About 31 percent of the utility wares are from Bullard Brushed vessels, including one body sherd with circular punctations pushed through the brushing. Five body sherds have either fingernail $(n=1)$ or tool $(n=4)$ punctated rows. Among the sherds with incised decorative elements are two rim sherds with cross-hatched incised lines, another rim sherd with diagonal incised lines, and a body sherd with a single straight incised line.

The most distinctive of the fine ware sherds is a grog-tempered Poynor Engraved, var. unspecified body sherd with two closely-spaced horizontal engraved lines and a large hatched pendant triangle or triangle element. The other fine ware sherds in the 41SM79 collection are body sherds with diagonal engraved lines $(n=1)$, curvilinear engraved lines $(n=3)$, parallel engraved lines $(n=1)$, a single straight engraved line $(n=1)$, and a body sherd with a single straight trailed line.

\section{$41 S M 80$}

41SM80 is a Frankston phase settlement "on a low hill or terrace" adjacent to and just above the Saline Creek floodplain (Johnson 1961:225); the creek is ca. $75 \mathrm{~m}$ to the east. The plotting of the site location on a USGS 7.5' topographic map indicates that the site is on an upland slope The small sample of grog and bonetempered sherds $(\mathrm{n}=24)$ from the site includes eight Bullard Brushed sherds and 16 plain sherds.

\section{$41 S M 81$}

This site was estimated by Johnson (1961:226) to cover ca. 3-5 acres of an eroded upland landform just east of the Saline Creek floodplain. The recovery of five grog-tempered Bullard Brushed sherds suggests the site was occupied by Caddo peoples during the Frankston phase.

\section{$41 S M 82$}

41SM82 is "on a low, flat hill above the western floodplain of Saline Creek" (Johnson 1961:226), about $160 \mathrm{~m}$ west of the creek. The site covers ca. 2 acres of a cotton field on the upland ridge landform, 
and when recorded had a midden deposit that was ca. $44 \mathrm{~cm}$ in thickness. In addition to one Perdiz arrow point (Johnson 1961:Figure 2c), the ceramic assemblage (both grog and bone-tempered) from a surface collection ( $n=190$ sherds) included sherds from Bullard Brushed ( $n=65)$, Maydelle Incised ( $n=6)$, and Poynor Engraved $(n=6)$ vessels. These sherds indicate that the site was occupied during the Frankston phase. Darrell Sanders and Sam Whiteside had told Johnson of the site.

\section{$41 S M 83$}

This site also has a Frankston phase component (ca. 1 acre in size) that is located on a low hill about 200 m west of the Saline Creek floodplain (Johnson 1961:226). Both Bullard Brushed (n=6) and Maydelle Incised $(n=9)$ sherds were identified in the site's small grog or bone-tempered ceramic sherd assemblage $(n=36)$. Southern Methodist University (SMU) visited the site in 1970 and noted one arrow point preform and 50 ceramic sherds over a ca. $50 \times 30 \mathrm{~m}$ area of the landform. The sherds included plain $(n=19)$, brushed ( $n=29)$, and two with incised decorative elements (Anderson 1972:190-191). These sherds were primarily from grog-tempered vessels.

\section{$41 S M 84$}

41SM84 is an ancestral Caddo occupation of unknown, but likely Frankston phase age that is located on a natural rise (covering ca. 0.5 acres) in a cultivated field just north of the Saline Creek floodplain (Johnson 1961:226). Only four plain sherds, six brushed sherds and an unidentified engraved sherd were found during the initial Lake Palestine survey.

\section{$41 S M 92$}

Little is known about the archaeological character of 41SM92. Johnson (1961:230) noted that the site was on a terrace landform across the Saline Creek floodplain from the Joe Meyer Estate \#1 site (41SM73), and was reported by Ray Vanderpool and L. A. Wallace to have considerable amounts of ceramic artifacts on the surface. The site was not revisited during the 1969-1970 Lake Palestine survey by SMU archaeologists.

\section{$41 S M 93$}

This ancestral Caddo site is on a natural rise, among a series of small rises or knolls, on the north side of County Line Creek. The site is both a habitation site as well as a cemetery. Red McFarland had excavated four ancestral Caddo burials of Frankston phase age here sometime before October 1970.

The burials were in extended supine position, with their heads facing to the southwest. Three of the burials had funerary offerings, including 12 ceramic vessels and three Perdiz arrow points. Among the vessels were four Hood Engraved effigy bowls, two Poynor Engraved bowls or carinated bowls, a possible Taylor Engraved bottle, two Bullard Brushed jars, a Killough Pinched jar, and a plain jar and a plain bowl. The Poynor Engraved vessel in Burial 1 was a var. Cook vessel while the Poynor Engraved vessel in Burial 3 was a var. Hood carinated bowl (see Perttula 2011:Figure 6-64).

\section{$41 S M 103$}

This site is primarily a $19^{\text {th }}$ century salt-making factory recorded by SMU archaeologists (see Skinner 1971), but there are ancestral Caddo habitation deposits of unknown age on it that underlie the salt factory remains. It is situated on a natural rise in the Saline Creek floodplain, in the Saline Prairie (see Figure 2).

\section{$41 S M 104$}

This site also has $19^{\text {th }}$ century salt factory remains on a terrace landform in the saline prairie floodplain, near the confluence of Saline Creek and County Line Creek (see Figure 2). However, Caddo 
ceramic sherds of an unknown age were noted on the site, and included sherds with punctated $(n=1)$, incised-punctated $(n=1)$, and engraved $(n=1)$ decorative elements.

\section{$41 S M 108$}

The ancestral Caddo occupation at this site is on the crest of an upland landform in the Saline Creek valley. SMU archaeologists estimated that the site covered a ca. $80 \times 50 \mathrm{~m}$ area of the landform, and they collected 21 grog and grog-bone-tempered sherds during their survey. The sherds were plain $(n=14)$, brushed $(n=6)$, and engraved $(n=1)$.

\section{$41 S M 113$}

Little is known of this ancestral Caddo site recorded by SMU. It was described as being located along the southern bank of Saline Creek. One plain grog-tempered sherd was noted on the surface by SMU archaeologists.

\section{$41 S M 116$}

41SM116 is a Frankston phase Caddo settlement on an upland landform east of an intermittent tributary that flows north to Saline Creek (see Figure 2). SMU archaeologists reported that one ancestral Caddo burial was dug at the site by Red McFarland's uncle ca. 1950; no information is available about the burial or its associated funerary offerings.

SMU archaeologists noted that the site, which covered a ca. $100 \times 50 \mathrm{~m}$ area (ca. 1.2 acres), had a heavy concentration of ceramic sherds on the surface. A total of 114 sherds were collected, 98 percent from grog-tempered vessels: 42 plain, 61 with brushed decorative elements, one punctated sherd, six sherds with incised decorative elements, and four engraved sherds; two sherds were identified as coming from Poynor Engraved vessels (Anderson 1972:188-189).

\section{$41 S M 117$}

SMU archaeologists identified this Frankston phase site on the crest of an upland landform on the west side of an intermittent tributary to Saline Creek. Ceramic sherds and mussel shell fragments were noted over a ca. 40 × $20 \mathrm{~m}$ area. The ancestral Caddo sherds $(n=15)$ included plain sherds $(n=8)$, brushed sherds $(n=3)$, one incised sherd, one fingernail punctated sherd, and two engraved sherds; one of the engraved sherds was from a Poynor Engraved vessel with a hatched triangle motif on the rim panel.

\section{$41 S M 118$}

This Caddo site was located on an upland slope landform on the south side of an intermittent tributary to Saline Creek (see Figure 2). The small site (estimated at $30 \times 15 \mathrm{~m}$ in size) had grog and grog-bone-tempered sherds, including 12 plain sherds, 26 brushed sherds, one incised sherds, and two engraved sherds, including one Poynor Engraved vessel sherd. The high proportion of brushed sherds in the assemblage, along with the Poynor Engraved fine ware sherd, indicates that 41SM118 was occupied during the Frankston phase.

\section{$41 S M 120$}

41SM120 is located on an upland landform east of an intermittent tributary to Saline Creek (see Figure 2). The site, whose size was undetermined by SMU archaeologists, appears to have had preserved midden deposits based on the preservation of animal bones and mussel shell fragments on the surface. A small sample of likely Late Caddo period ceramic vessel sherds were collected from the site, including four plain sherd, eight brushed sherds, and one incised sherd (Anderson 1972:190-191). 


\section{$41 S M 122$}

This ancestral Caddo site is on a low upland ridge slope along a northward-flowing tributary to Saline Creek; its size was not determined. A few Caddo grog-tempered sherds were noted on the surface by SMU archaeologists, including two plain sherds and two brushed sherds.

\section{$41 S M 123$}

41SM123 is a small ancestral Caddo site of Late Caddo period, Frankston phase age on an terrace landform in the Saline Creek valley, east of the creek. Ceramic sherds were found on the surface by SMU archaeologists over a ca. $35 \times 35 \mathrm{~m}$ area of the landform, and these grog-tempered sherds included nine plain sherds, 18 brushed sherds, three tool punctated sherds, one La Rue Neck Banded sherd, and one Poynor Engraved, var. Cook carinated bowl sherd.

\section{$41 S M 124$}

This is an ancestral Caddo site of Frankston phase age on an eroded upland landform along a tributary stream to Saline Creek (see Figure 2). SMU archaeologists collected 72 ceramic sherds from the site, among them 48 plain sherds, 20 Bullard Brushed sherds, three incised sherds, and one sherd with tool punctations.

\section{$41 S M 126$}

41SM126 is located on an upland ridge between two small streams, including Frock Run, a southward-flowing tributary to Saline Creek in the Saline Creek valley. The site is estimated to cover a ca. 50 x $50 \mathrm{~m}$ area of the landform, and 37 ceramic sherds were noted on the surface by SMU archaeologists. These sherds, from grog-tempered vessels, were plain $(n=16)$, brushed $(n=16)$, fingernail punctated $(n=1)$, incised $(n=3)$, and engraved $(n=1)$.

\section{$41 S M 127$}

Only a small (ca. $10 \times 10 \mathrm{~m}$ ) surface scatter of ancestral Caddo ceramic sherds was noted by SMU archaeologists at 41SM127. The sherds were along an upland ridge slope overlooking a small intermittent stream that flows into Frick Creek, a southward-flowing tributary to Saline Creek. The 18 ceramic sherds include 10 plain sherds and eight brushed sherds.

\section{$41 S M 129$}

This Frankston phase Caddo site is on upland landform ca. $1.9 \mathrm{~km}$ north and west of Saline Creek (see Figure 2), near the Neches River floodplain. SMU archaeologists noted only a small scatter (15 x 3 $\mathrm{m}$ ) of ceramic sherds on the surface. The sherds included four plain and three Poynor Engraved vessel sherds (Anderson 1972:190-191).

\section{Cedar Bay (41SM151)}

The Cedar Bay site (41SM151) is an ancestral Caddo cemetery and habitation area on a knoll north of County Line Creek; the habitation area is ca. $15 \mathrm{~m}$ from the cemetery. Red McFarland, a local collector, Ray Moseley, and Jimmy Cohagan dug two burials at the cemetery: one burial supposedly had four individuals and the other had three individuals, but it is possible that these burials actually represent seven distinct burial pits in an area about $10 \times 2 \mathrm{~m}$ in size. Funerary offerings included 21 ceramic vessels (including two Hood Engraved effigy vessels and a Bullard Brushed jar), 18 Perdiz arrow points, one Jowell knive, one celt, and one ceramic elbow pipe. 


\section{William Sherman Burial (41SM158)}

The William Sherman Burial site is an ancestral Caddo cemetery of Frankston phase age on a terrace landform south of County Line Creek. Four Caddo burials had been excavated at the site by either Red McFarland or Charlie Stevens; they were in one north-south row in extended supine position with their heads facing west.

The four burials had a total of 19 ceramic vessels, and these had been placed in the burials as funerary offerings. Among the identified vessels were those of the Poynor Engraved and Maydelle Incised types, as well as bottles, bowls, and a bowl that had horizontal engraved lines with large triangular elements on the lines; this vessel is likely a Poynor Engraved, var. $C$ vessel (see Perttula 2011:Figure 6-65). One of the plain bowls had a scalloped lip.

\section{Cedar Bay (41SM249)}

There are 10 vessels from three Late Caddo period, Frankston phase (ca. A.D. 1400-1650), burials at 41SM249 (see Perttula et al. 2009:65-74). These burials were excavated in March 1971 by J. A. Walters. One of the burials was described as being in an extended supine position with the head facing to the southwest; ceramic vessels were placed as funerary offerings around the head and the left shoulder. The burial pit floors lay between 101-107 cm bs.

This site is located in the upper Neches River basin, on a lower upland slope near and north of County Line creek in the Lake Palestine area but upstream from the lake itself (see Figure 2). The vessels include plain bowls $(n=2)$, bottles $(n=1)$, and carinated bowls $(n=1)$, Bullard Brushed $(n=1)$, a brushed-punctated jar $(\mathrm{n}=1)$, Poynor Engraved, var. Blackburn $(\mathrm{n}=1)$, Poynor Engraved, var. unspecified $(\mathrm{n}=1)$, a Hood Engraved, var. Hood effigy vessel $(\mathrm{n}=1)$, and a unique punctated bottle $(\mathrm{n}=1)$. Poynor Engraved, var. Blackburn and Hood Engraved, var. Hood vessels are present in burials dating to each of the three sub-phases of the Frankston phase, but they are most common in contexts thought to date from ca. A.D. 1400-1560 (Perttula 2011:Table 6-37).

SITE NAME OR SITE NUMBER: 41SM249

VESSEL NO.: 104

NON-PLASTICS: grog; sandy paste

VESSEL FORM: Shallow bowl (Figure 49)

RIM AND LIP FORM: Everted rim and a rounded lip

CORE COLOR: $\mathrm{G}$ (fired in a reducing environment and cooled in the open air)

INTERIOR SURFACE COLOR: brown (7.5YR 4/2)

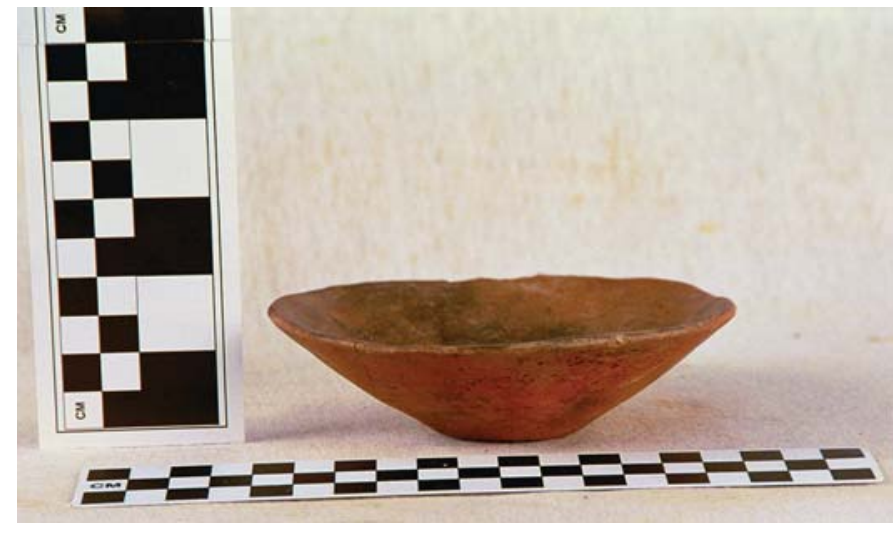

Figure 49. Plain shallow bowl from 41SM249.

EXTERIOR SURFACE COLOR: reddish-yellow (5YR 6/6); fire clouds on the base

WALL THICKNESS (RIM, BODY, AND BASE IN MM): $5.2 \mathrm{~mm}$, rim

INTERIOR SURFACE TREATMENT: smoothed 
EXTERIOR SURFACE TREATMENT: smoothed

HEIGHT (IN CM): 3.5

ORIFICE DIAMETER (IN CM): 11.6

DIAMETER AT BOTTOM OF RIM OR NECK (IN CM): N/A

BASE DIAMETER (IN CM): 4.0

ESTIMATED VOLUME (IN LITERS): 0.16 liters

DECORATION: Plain

TYPE: Undetermined plain ware

SITE NAME OR SITE NUMBER: 41SM249, Burial 1

VESSEL NO.: 136

NON-PLASTICS: grog

VESSEL FORM: Jar with two opposing rim lugs (Figure 50)

RIM AND LIP FORM: Everted rim and a rounded lip

CORE COLOR: $\mathrm{G}$ (fired in a reducing environment and cooled in the open air)

INTERIOR SURFACE COLOR: very dark grayish-brown (10YR 3/2)

EXTERIOR SURFACE COLOR: dark yellowish-brown (10YR 4/4)

WALL THICKNESS (RIM, BODY, AND

BASE IN MM): $7.0 \mathrm{~mm}$, rim

INTERIOR SURFACE TREATMENT:

smoothed

EXTERIOR SURFACE TREATMENT: none

HEIGHT (IN CM): 20.5

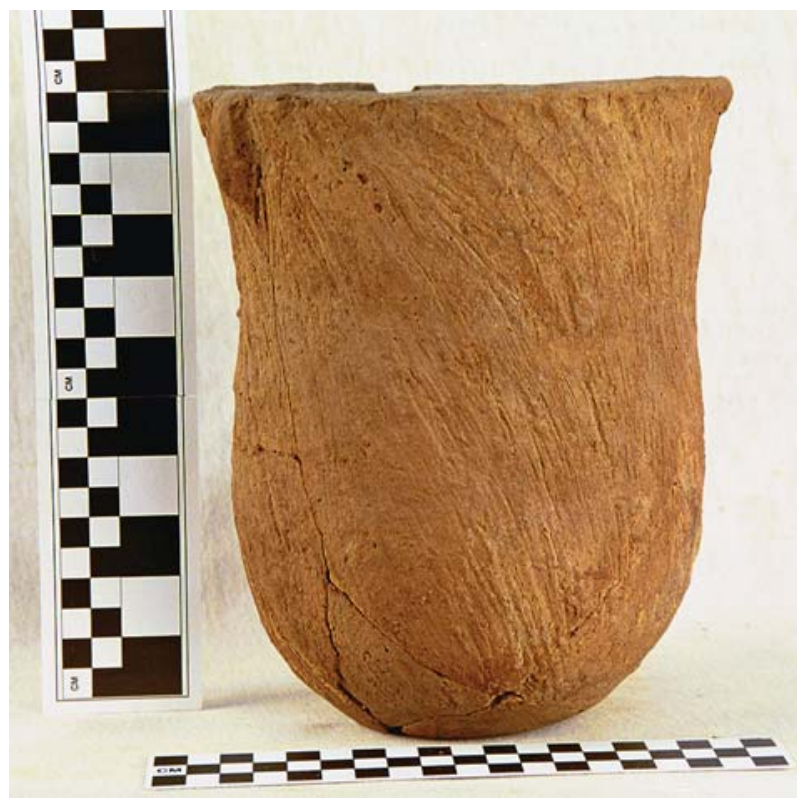

Figure 50. Bullard Brushed jar from 41SM249, Burial 1.

ORIFICE DIAMETER (IN CM): 16.8

DIAMETER AT BOTTOM OF RIM OR NECK (IN CM): 14.2

BASE DIAMETER (IN CM): 7.0 
ESTIMATED VOLUME (IN LITERS): 3.1 liters

DECORATION: Diagonal to vertical brushing on the rim and vessel body, stopping just above the base of the vessel (see Figure 50).

TYPE: Bullard Brushed

SITE NAME OR SITE NUMBER: 41SM249, Burial 1

VESSEL NO.: 137

NON-PLASTICS: grog

VESSEL FORM: Globular carinated bowl

RIM AND LIP FORM: Direct rim and a flat lip

CORE COLOR: A (oxidized during firing and cooling)

INTERIOR SURFACE COLOR: brownish-yellow (10YR 6/6)

EXTERIOR SURFACE COLOR: yellowish-red (5YR 5/8)

WALL THICKNESS (RIM, BODY, AND BASE IN MM): $4.5 \mathrm{~mm}$, rim; $5.2 \mathrm{~mm}$, body

INTERIOR SURFACE TREATMENT: smoothed

EXTERIOR SURFACE TREATMENT: smoothed

HEIGHT (IN CM): 9.8

ORIFICE DIAMETER (IN CM): 15.0

DIAMETER AT BOTTOM OF RIM OR NECK

(IN CM): 13.0

BASE DIAMETER (IN CM): 5.0

ESTIMATED VOLUME (IN LITERS): 0.88 liters

DECORATION: The rim has 14 rectangular engraved panels defined by sets of vertical engraved lines at either end of the panel. Each panel also contains a single large excised pendant triangle, with their apex alternating between pointing towards the rim or pointing towards the carination/base (Figure 51).

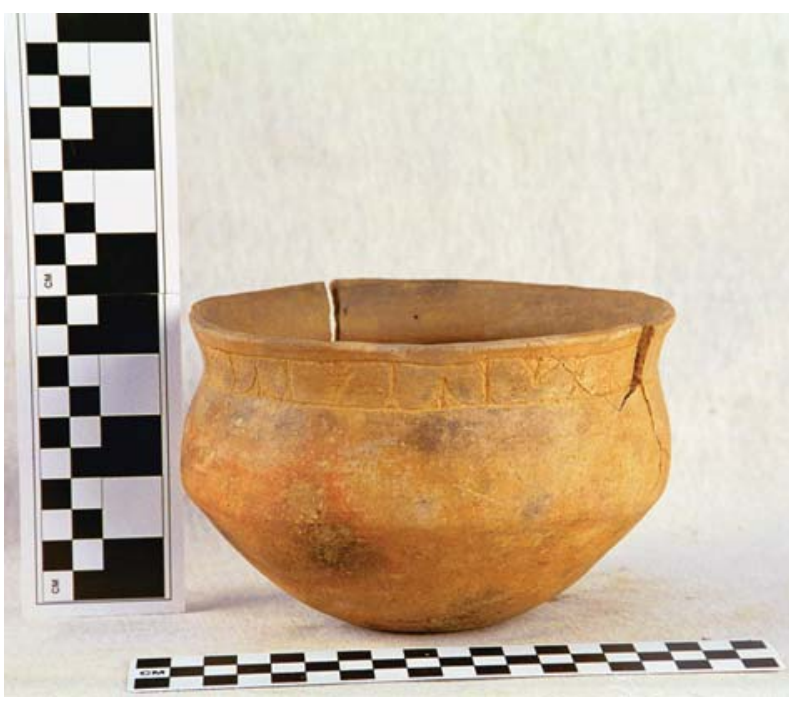

Figure 51. Poynor Engraved, var. Blackburn carinated bowl from Burial 1 at 41SM249.

TYPE: Poynor Engraved, var. Blackburn 
SITE NAME OR SITE NUMBER: 41SM249

VESSEL NO.: 138

NON-PLASTICS: grog and hematite

VESSEL FORM: Carinated bowl

RIM AND LIP FORM: Direct rim and a rounded lip

CORE COLOR: C (incompletely oxidized during firing)

INTERIOR SURFACE COLOR: brownish-yellow (7.5YR 6/5)

EXTERIOR SURFACE COLOR: brownish-yellow (7.5YR 6/5)

WALL THICKNESS (RIM, BODY, AND BASE IN MM): 6.7 mm, rim

INTERIOR SURFACE TREATMENT: smoothed

EXTERIOR SURFACE TREATMENT:

smoothed

HEIGHT (IN CM): 11.4

ORIFICE DIAMETER (IN CM): 20.4

DIAMETER AT BOTTOM OF RIM OR NECK

(IN CM): 21.0

BASE DIAMETER (IN CM): 8.5

ESTIMATED VOLUME (IN LITERS): 1.39 liters

DECORATION: Plain (Figure 52)

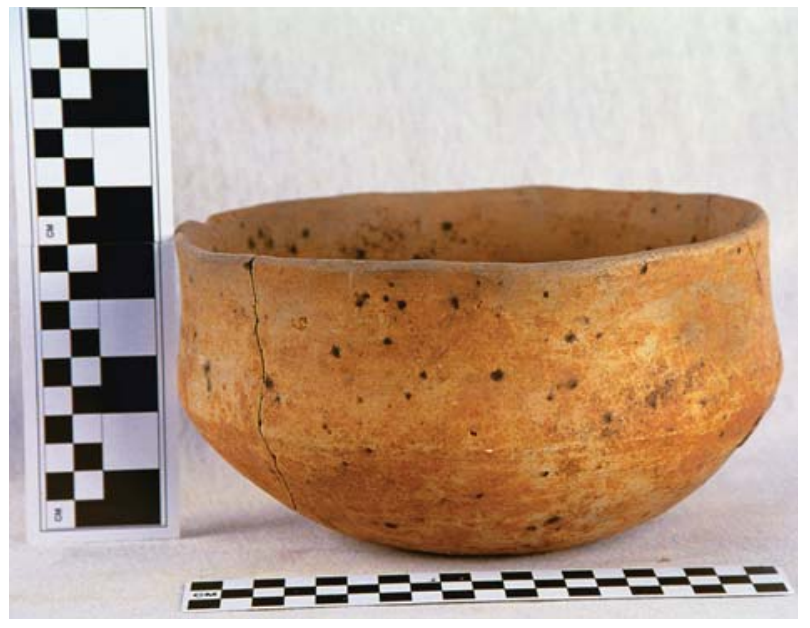

Figure 52. Plain carinated bowl from 41SM249.

TYPE: Undetermined plain ware

SITE NAME OR SITE NUMBER: 41SM249, Burial 2

VESSEL NO.: 141

NON-PLASTICS: grog

VESSEL FORM: Bottle with a straight neck

RIM AND LIP FORM: Direct rim and a rounded lip

CORE COLOR: $\mathrm{F}$ (fired in a reducing environment and cooled in the open air)

INTERIOR SURFACE COLOR: grayish-brown (10YR 5/2) 
EXTERIOR SURFACE COLOR: grayish-brown (10YR 5/2)

WALL THICKNESS (RIM, BODY, AND BASE IN MM): 5.4 mm, rim

INTERIOR SURFACE TREATMENT: none

EXTERIOR SURFACE TREATMENT: smoothed

HEIGHT (IN CM): 20.0

ORIFICE DIAMETER (IN CM): 4.6

DIAMETER AT BOTTOM OF RIM OR NECK (IN CM): $5.7 ; 16.0 \mathrm{~cm}$ at the widest part of the body

BASE DIAMETER (IN CM): 8.0

ESTIMATED VOLUME (IN LITERS): 0.64 liters

DECORATION: The rim panel has four swastika-in-circle motifs within negative circles formed by cross-hatched brackets and upper and lower fill zones. There are four smaller negative circles within the cross-hatched brackets (Figure 53). The swastika-in-circle is a motif that is associated with the Beneath World or Underwater Realm (Reilly 2004:129-130).

TYPE: cf. Poynor Engraved, var. unspecified

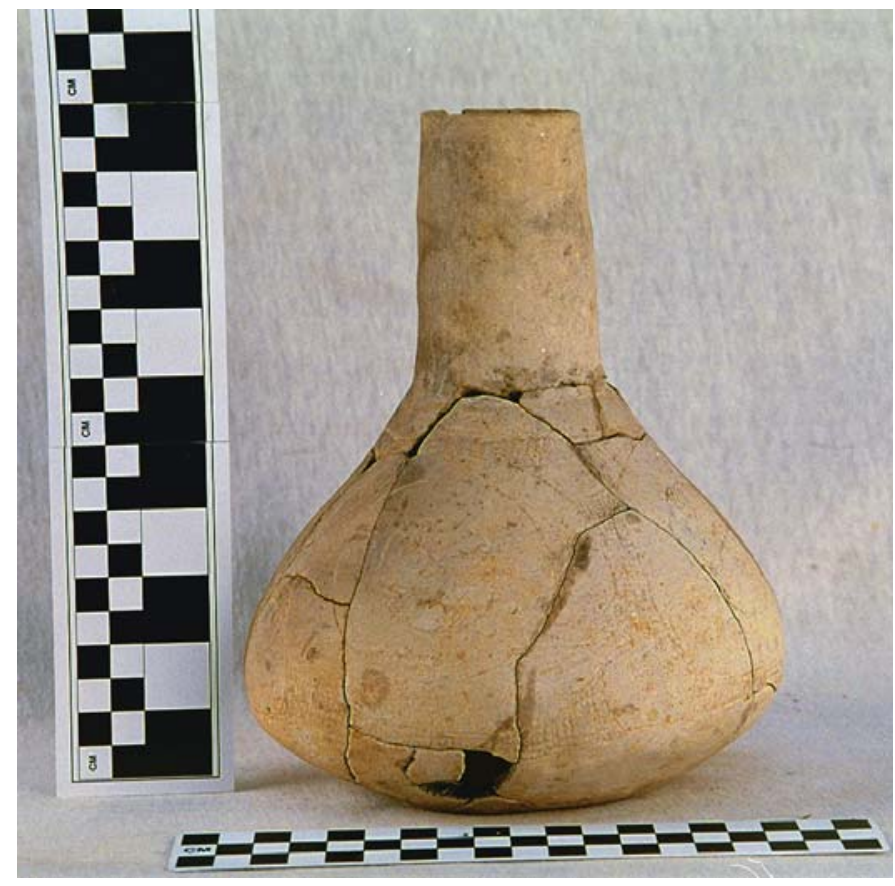

Figure 53. Poynor Engraved, var. unspecified bottle from $41 \mathrm{SM} 249$.

SITE NAME OR SITE NUMBER: 41SM249, Burial 2

VESSEL NO.: 142

NON-PLASTICS: grog and bone; sandy paste

VESSEL FORM: Jar

RIM AND LIP FORM: Everted rim and a rounded lip

CORE COLOR: $\mathrm{G}$ (fired in a reducing environment and cooled in the open air)

INTERIOR SURFACE COLOR: very dark gray (10YR 3/1)

EXTERIOR SURFACE COLOR: yellowish-brown (10YR 5/4)

WALL THICKNESS (RIM, BODY, AND BASE IN MM): 9.2 mm, rim 
INTERIOR SURFACE TREATMENT: smoothed

EXTERIOR SURFACE TREATMENT: none

HEIGHT (IN CM): 13.0

ORIFICE DIAMETER (IN CM): 10.5

DIAMETER AT BOTTOM OF RIM OR

NECK (IN CM): 9.3

BASE DIAMETER (IN CM): 7.8

ESTIMATED VOLUME (IN LITERS):

0.82 liters

DECORATION: The rim has three widelyspaced rows of tool punctations. The body, except near the base, has overlapping brushing marks (Figure 54).

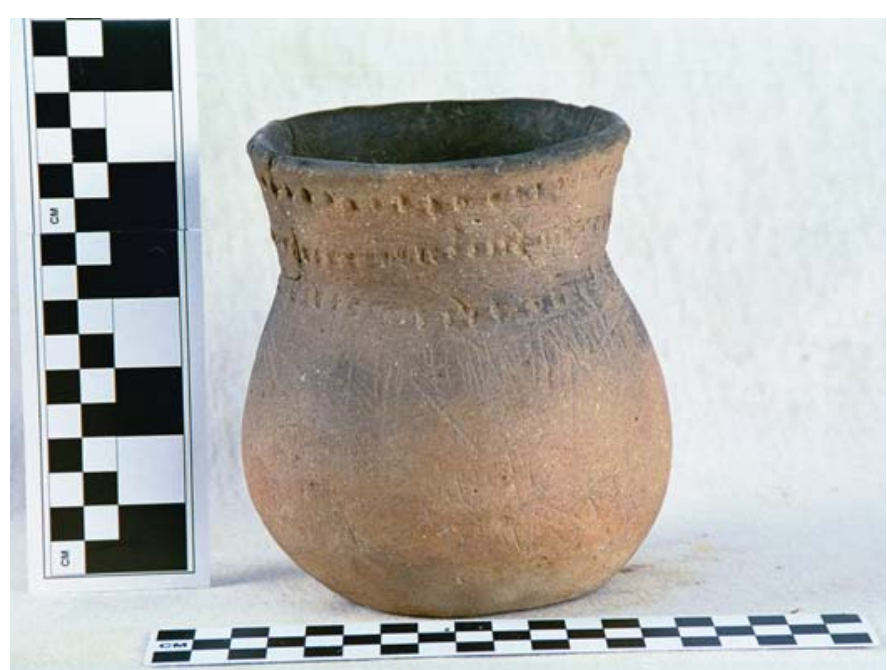

Figure 54. Brushed-punctated jar from Burial 2 at 41SM249.

TYPE: Undetermined utility ware

SITE NAME OR SITE NUMBER: 41SM249, Burial 3

VESSEL NO .: 150

NON-PLASTICS: grog

VESSEL FORM: Bowl (Figure 55)

RIM AND LIP FORM: Direct rim and a rounded lip

CORE COLOR: A (fired and cooled in a high oxygen environment)

INTERIOR SURFACE COLOR: light yellowish-brown (10YR 6/4)

EXTERIOR SURFACE COLOR: light yellowish-brown (10YR 6/4)

WALL THICKNESS (RIM, BODY, AND

BASE IN MM): $4.2 \mathrm{~mm}$, rim

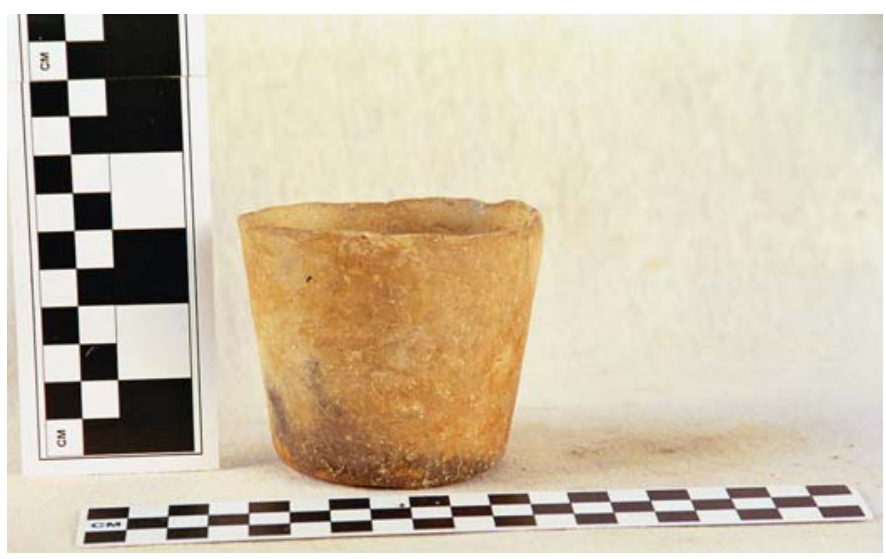

Figure 55. Plain bowl from 41SM249, Burial 3.

INTERIOR SURFACE TREATMENT: none

EXTERIOR SURFACE TREATMENT: smoothed

HEIGHT (IN CM): 6.8 
ORIFICE DIAMETER (IN CM): 7.7

DIAMETER AT BOTTOM OF RIM OR NECK (IN CM): N/A

BASE DIAMETER (IN CM): 5.9

ESTIMATED VOLUME (IN LITERS): 0.21 liters

DECORATION: Plain

TYPE: Undetermined plain ware

SITE NAME OR SITE NUMBER: 41SM249, Burial 1

VESSEL NO.: 224

NON-PLASTICS: grog

VESSEL FORM: Cylindrical bottle

RIM AND LIP FORM: Direct rim and a flat lip

CORE COLOR: A (fired and cooled in a high oxygen environments)

INTERIOR SURFACE COLOR: brownish-yellow (10YR 6/8)

EXTERIOR SURFACE COLOR: brownish-yellow (10YR 6/8)

WALL THICKNESS (RIM, BODY, AND BASE IN $\mathrm{MM}): 8.6 \mathrm{~mm}$, rim

INTERIOR SURFACE TREATMENT: none

EXTERIOR SURFACE TREATMENT: burnished

HEIGHT (IN CM): 26.4

ORIFICE DIAMETER (IN CM): 4.6

DIAMETER AT BOTTOM OF RIM OR NECK (IN CM): N/A

BASE DIAMETER (IN CM): 9.9

ESTIMATED VOLUME (IN LITERS): 1.05 liters

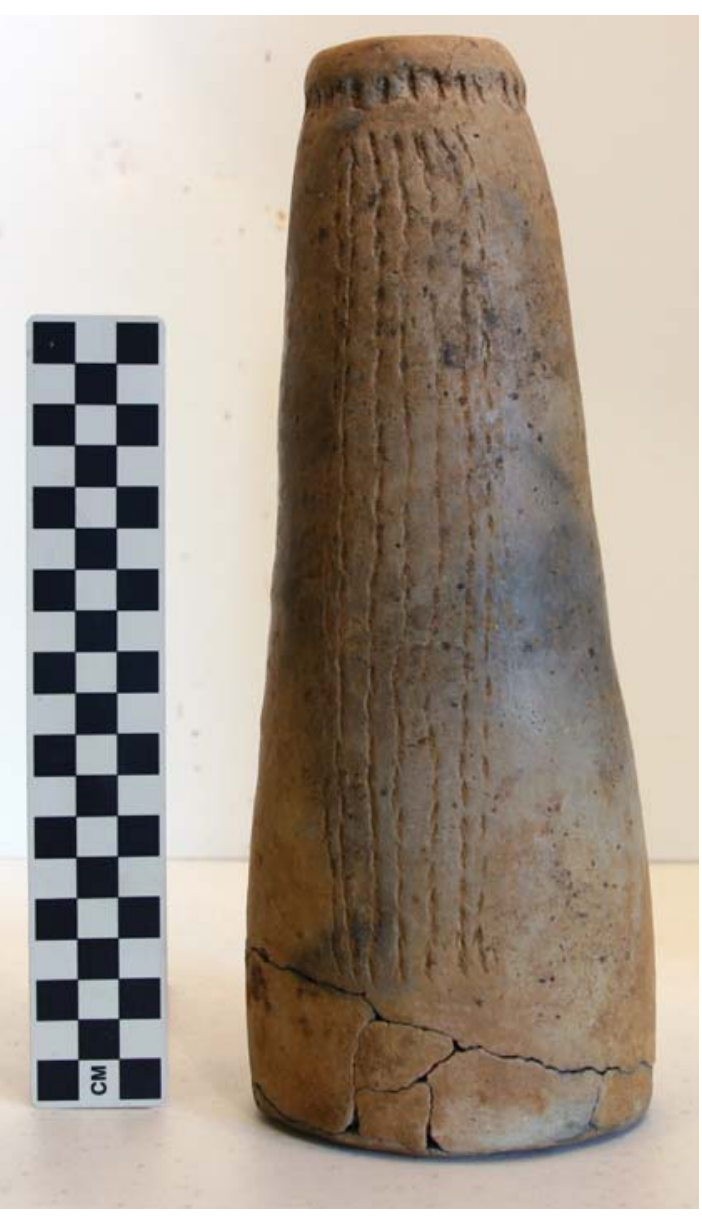

Figure 56. Punctated bottle from Burial 1 at $41 \mathrm{SM} 249$. 
DECORATION: There is a single tool punctated row at the juncture of the bottle neck and the body. The body has three vertical sets of punctations, one with six closely-spaced vertical rows; one with seven vertical rows of closely-spaced punctations; and the third with eight vertical rows of tool punctations (Figure 56).

TYPE: Undetermined fine ware; the vessel form is consistent with certain Poynor Engraved bottles (see Suhm and Jelks 1962:Plate 63f)

SITE NAME OR SITE NUMBER: 41SM249, Burial 3

VESSEL NO.: 226

NON-PLASTICS: grog

VESSEL FORM: Bowl with a bird effigy head $(4.0 \mathrm{~cm}$ in height and width) and tab tail $(3.5 \mathrm{~cm}$ wide and 1.5 $\mathrm{cm}$ in length) (Figure 57)

RIM AND LIP FORM: Direct rim and a flat lip

CORE COLOR: $\mathrm{F}$ (fired in a low oxygen environment and cooled in the open air)

INTERIOR SURFACE COLOR: dark grayish-brown (10YR 4/2)

EXTERIOR SURFACE COLOR:

dark yellowish-brown (10YR 4/4)

WALL THICKNESS (RIM, BODY, AND

BASE IN MM): $6.7 \mathrm{~mm}$, rim

INTERIOR SURFACE TREATMENT:

smoothed on the rim

EXTERIOR SURFACE TREATMENT:

burnished

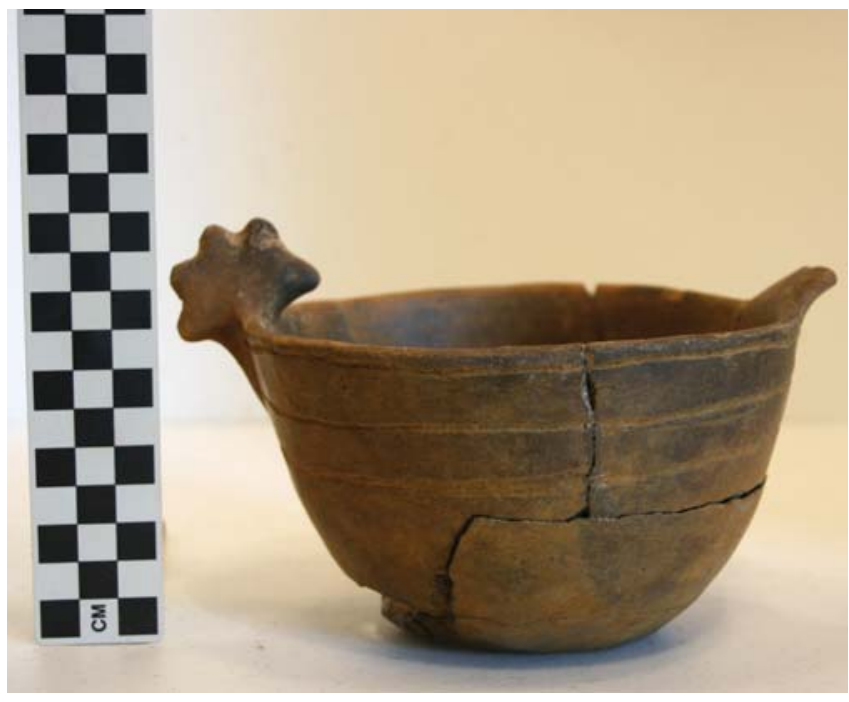

HEIGHT (IN CM): 8.6

Figure 57. Hood Engraved, var. Hood effigy bowl, 41SM249, Burial 3.

ORIFICE DIAMETER (IN CM): 14.4

DIAMETER AT BOTTOM OF RIM OR NECK (IN CM): N/A

BASE DIAMETER (IN CM): 7.0

ESTIMATED VOLUME (IN LITERS): 0.50 liters

DECORATION: There are three broad horizontal engraved lines encircling the vessel rim; the lines are not continuous, but are divided by raised ridges underneath the effigy head and the tab tail (see Figure 57).

TYPE: Hood Engraved, var. Hood 
SITE NAME OR SITE NUMBER: 41SM249, Burial 3

VESSEL NO.: 237

NON-PLASTICS: grog

VESSEL FORM: Bottle with a straight neck and a carinated body (Figure 58)

RIM AND LIP FORM: Direct rim and a rounded lip

CORE COLOR: $\mathrm{F}$ (fired in a low oxygen environment and cooled in the open air)

INTERIOR SURFACE COLOR: reddish-yellow (7.5YR 5/6)

EXTERIOR SURFACE COLOR: reddish-yellow (7.5YR 5/6); fire clouding on the body, neck, and base

WALL THICKNESS (RIM, BODY, AND BASE IN MM): $5.7 \mathrm{~mm}$, rim

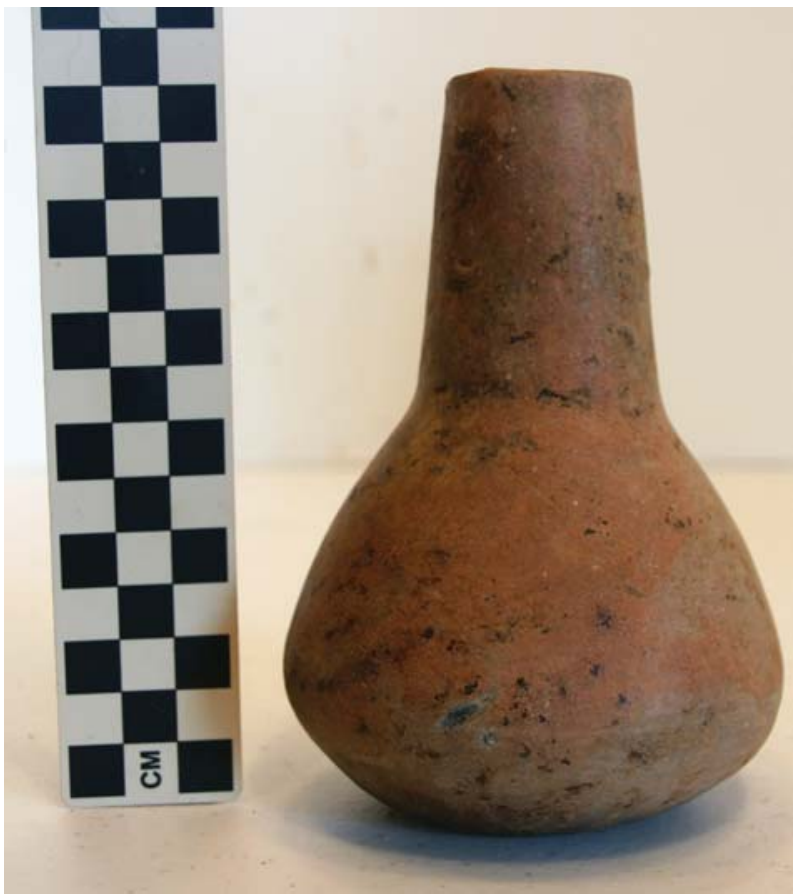

Figure 58. Plain bottle from Burial 3 at 41SM249.

EXTERIOR SURFACE TREATMENT:

smoothed

HEIGHT (IN CM): 13.5; the neck is $6.0 \mathrm{~cm}$ in length

ORIFICE DIAMETER (IN CM): 3.3

DIAMETER AT BOTTOM OF RIM OR NECK (IN CM): 4.5; maximum width is $9.4 \mathrm{~cm}$

BASE DIAMETER (IN CM): 5.5

ESTIMATED VOLUME (IN LITERS): 0.30 liters

DECORATION: Plain

TYPE: Undetermined plain ware 


\section{Trant (41SM468)}

The Trant site is an ancestral Caddo cemetery where numerous burials, likely of Frankston phase age, were excavated during the 1970s by local collector Red McFarland. The burials contained ceramic vessels and arrow points as funerary offerings. The site was located on an upland ridge north and west of Saline Creek.

\section{Saline Creek Site}

The Saline Creek site is a previously undocumented, but still unrecorded, Late Caddo, Frankston phase cemetery on Saline Creek in Smith County, Texas, that was excavated by Buddy Jones, Ray Vanderpool, L. A. Wallace, and Bill Cox in November 1956. Its exact location is not known, but it is likely to have been located very near the Vanderpool site (41SM77), also on Saline Creek upstream from the upper part of the Lake Palestine flood pool along the creek (see Figure 2).

Burials 1 and 2 were excavated at the site in 1956, which was in a cotton field along the west side of Saline Creek (Figure 59). No vessels or other funerary offerings from the two burials have been identified in the Gregg County Museum collections from the site, but burial and vessel drawings are available, and these materials form the basis of our documentation. The two burials were in pits that were oriented northwest-southeast, likely with the head of the deceased at the southeast end of the pit, facing northwest. Both burial pits extended a short distance into the underlying B-horizon clay.

Burial 1 had six ceramic vessels placed along the body of the deceased, from the skull area to the lower legs; the human remains were very fragmentary. Based on vessel drawings, these vessels included a Poynor Engraved cylindrical bottle, two Hood Engraved, var. Hood effigy bowls, two broken carinated bowls of uncertain decoration, and a large Poynor Engraved, var. Hood carinated bowl along what would have been the lower legs (Figure 60).

Amidst the ceramic vessel funerary offerings were several stone tools. These were a large ovalshaped biface, a ground stone celt, and a tight cluster of eight Perdiz arrow points. The points and the celt may have been inside a leather pouch when they were placed in the grave.

Burial 2 had five ceramic vessels as funerary offerings. By the head of the deceased were a longnecked bottle, a plain everted rim jar, and a cylindrical Hume Engraved bottle (Figure 61). Near the lower legs and feet were a small Killough Pinched jar and a Hood Engraved, var. Hood effigy bowl. Eight Perdiz arrow points were scattered along and above the body of the deceased. Near the upper part of the burial, above the head area, was a charcoal concentration (Figure 61), suggesting that a fire had been built and maintained in the grave after it had been partially filled in.

The occurrence of Hood Engraved, var. Hood effigy bowls, a Hume Engraved bottle, and a Poynor Engraved, var. Hood carinated bowl from the two burials-along with the Killough Pinched jar-confirm that the burials are from a Frankston phase cemetery. The engraved fine wares suggest that the cemetery was in use between ca. A. D. 1480-1560 (Perttula 2011:Table 6-37).

\section{Summary and Conclusions}

Since the early 1930s, a total of 38 ancestral Caddo sites have been identified and recorded in the Saline Creek and County Line Creek valleys of the upper Neches River basin in East Texas. It is likely that this represents only a very small proportion of the total number of Caddo sites once present in these two valleys, as it is clear these valleys were heavily settled at certain times by Caddo peoples. 


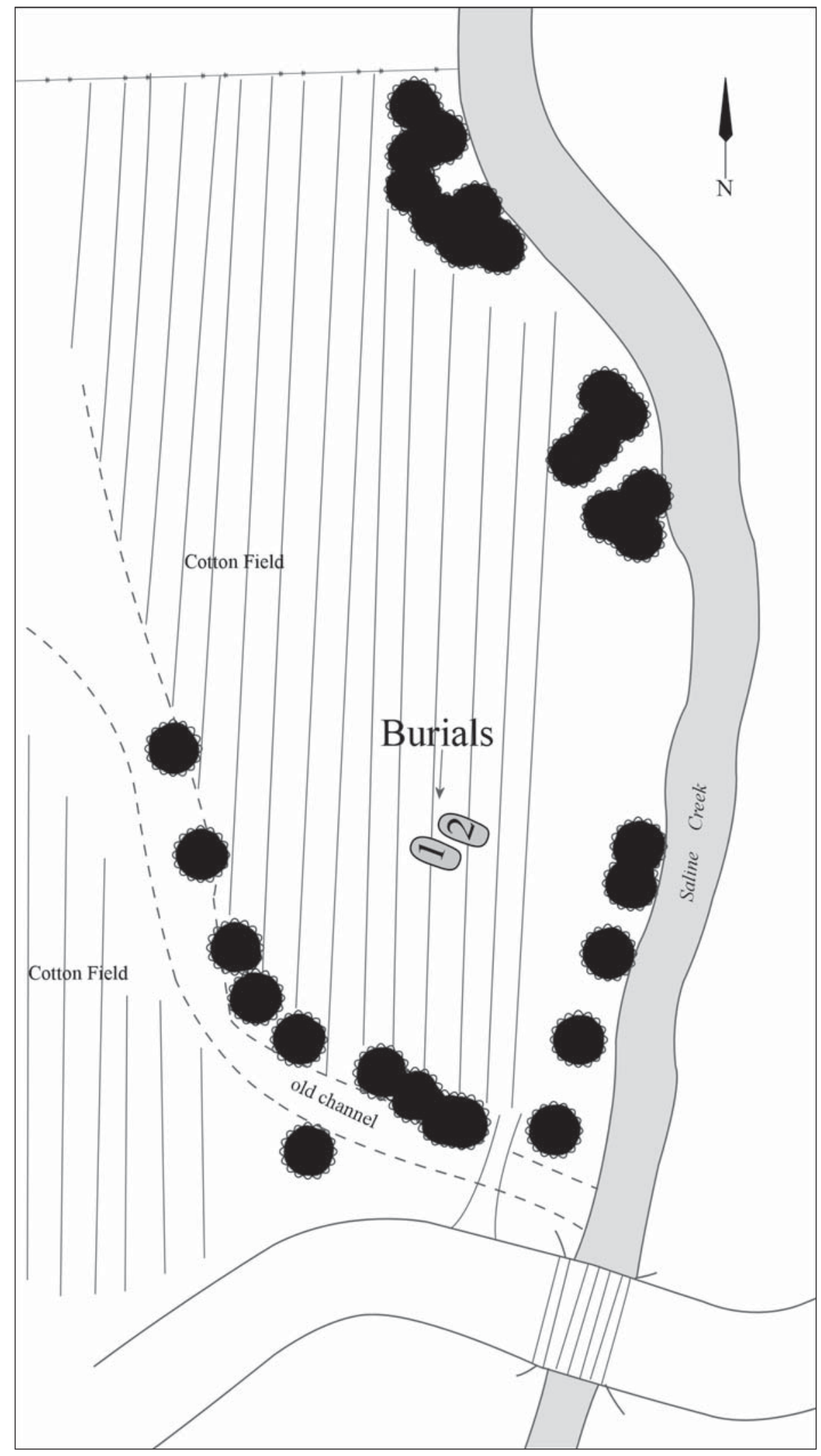

Figure 59. Location of Burials 1 and 2 at the Saline Creek site, Smith County, Texas. 


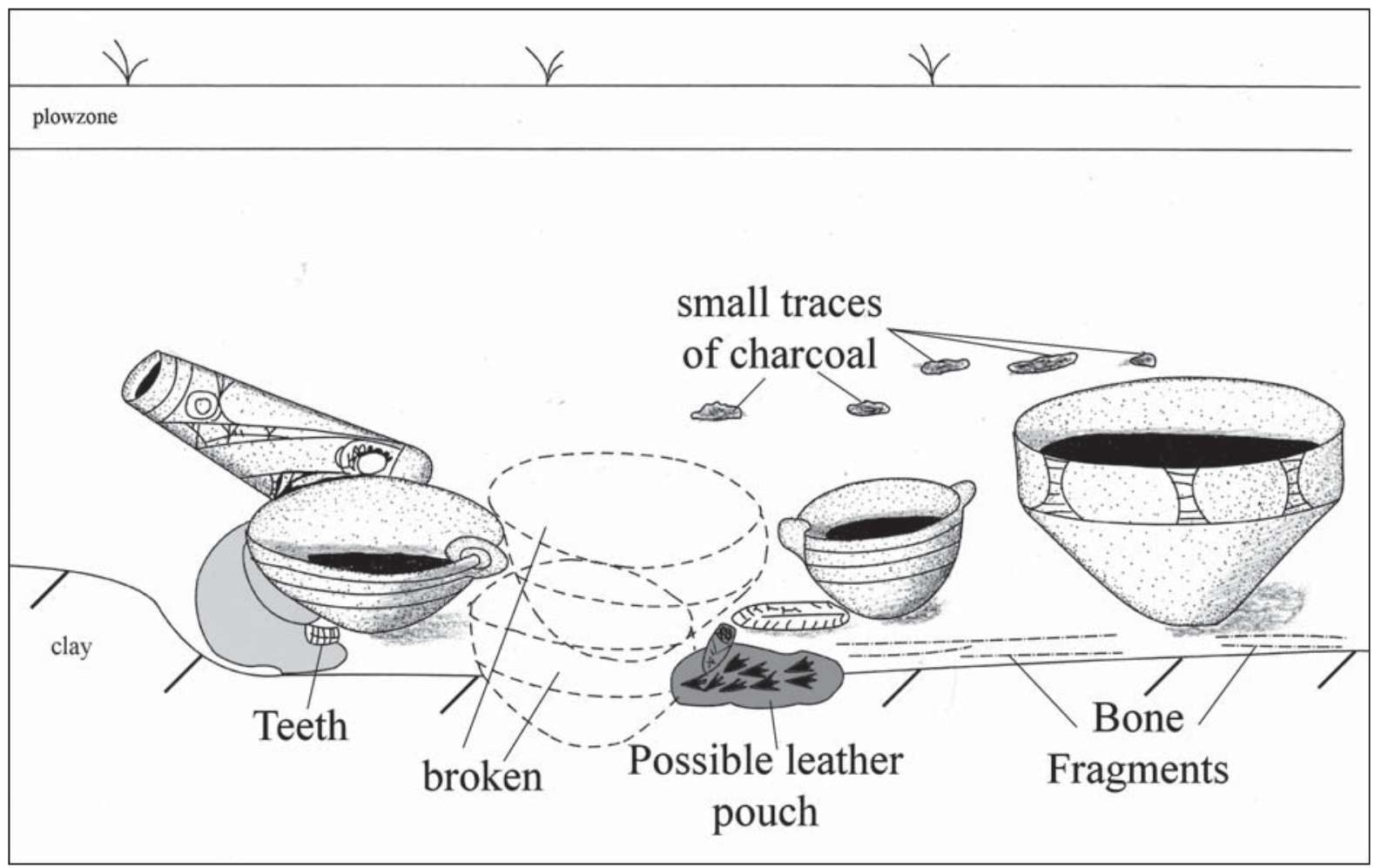

Figure 60. Drawing of Burial 1 at the Saline Creek site.

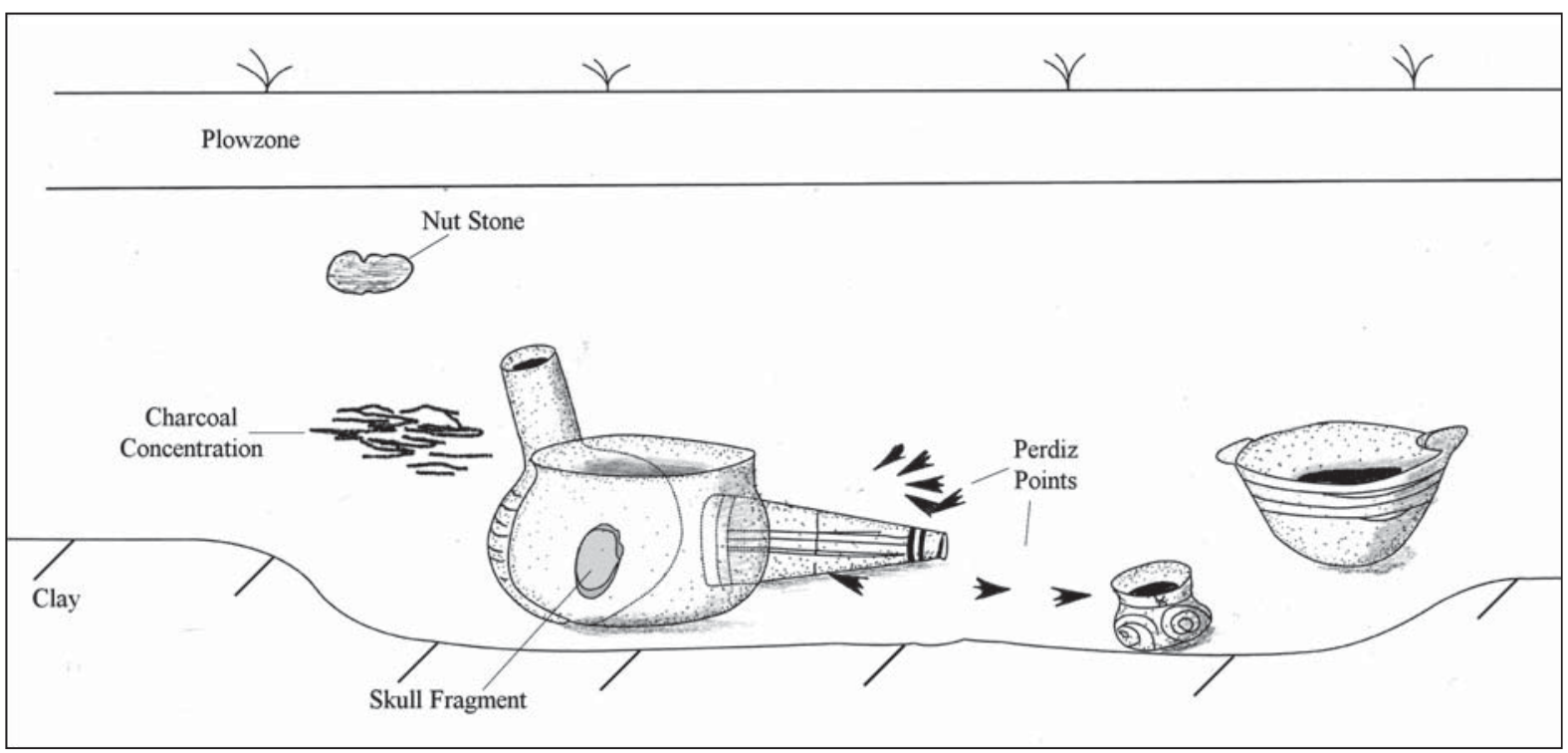

Figure 61. Drawing of Burial 2 at the Saline Creek site.

In general, almost all of the Saline Creek and County Line Creek Caddo sites have archaeological materials that date after A.D. 1400, during the Frankston phase, as 23 of the ancestral Caddo sites date to the Late Caddo period. Another six sites have components that can only be dated to a period after ca. A.D. 1200-1250, when brushed utility ware ceramic vessels began to be made and used by Caddo groups in the upper Neches River basin. Nine sites in the Saline Creek basin were settled by Caddo peoples, but not enough archaeological information is available to indicate when these settlements occurred. The Joe Meyer Estate \#1 site (41SM73) has a major Early Caddo period component (ca. A.D. 1000-1200) with habitation 
and cemetery features, and there is also an Early Caddo period settlement at nearby 41SM76. This temporal data suggests an initial Caddo settlement of the Saline Creek valley between ca. A.D. 1000-1200, followed by ca. 200 years of little use, and then a resettlement of the Saline and County Line creek valleys by Caddo farmers after ca. A.D. 1400. Eight of the 13 Caddo cemeteries known in the Saline and County Line creek valleys were used as burial grounds during the Frankston phase, and three others likely also date their use by Caddo groups to this same period. These farmers remained in the two valleys until the late $17^{\text {th }}$-early $18^{\text {th }}$ century, but most of the Caddo population had left the valleys by ca. A.D. 1680 .

There is one burial (Burial 3) at the Vanderpool site (41SM77) that has European trade goods $(+800$ glass beads) and Patton Engraved ceramic vessels that indicate this interment dates to the late $17^{\text {th }}$-early $18^{\text {th }}$ century, during the post-A.D. 1650 Allen phase. This burial is one of a relatively low number of upper Neches River basin sites that have European trade goods found together with Caddo archaeological material remains, either found in burial associations (Cole 1975; Kleinschmidt 1982; Marceaux 2011; Perttula 2010; Perttula et al. 2011:403-433) or from habitation contexts (Perttula and Nelson 2007; Walters and Perttula 2012), and thus they document contact between the Caddo groups living in this region and European traders.

The seriation of fine ware vessels in the upper Neches River basin by Perttula (2011:Table 6-37) suggests that the sites with burial features discussed in this publication date primarily between A.D. 14801650, although there may have been use of some of the sites between A.D. 1400-1480 as well, and one burial from the Vanderpool site dates from the late $17^{\text {th }}$-early $18^{\text {th }}$ century.

This temporal estimation is based on the common occurrence of Poynor Engraved, var. Hood and var. Freeman vessels on Saline Creek sites (mostly in mortuary contexts) that date from A.D. 1480-1650 in other upper Neches River basin sites, Poynor Engraved, var. Blackburn and var. Cook from ca. A.D. 1400-1560, and the frequency of Hood Engraved effigy bowls between ca. A.D. 1400-1560. Hume Engraved bottles occur only in ca. A.D. 1480-1650 mortuary contexts. Regarding the regional varieties of Poynor Engraved in the present set of sites, Var. I and Var. S are present in ca. A.D. 1400-1480 mortuary vessels identified in mortuary contexts in other sites in the basin, while Var. $D$ has been found in ca. A.D. 1480-1560 contexts, and Var. $E$ is present in cemeteries that date from ca. A.D. 1480-1650. In summary, the material culture remains (including mortuary vessels) from the known ancestral Caddo sites in the Saline Creek valley are evidence of ancestral Caddo use of this region for at least a 700 year period, from ca. A.D. 1000-1200 and ca. A.D. 1400 to the early $18^{\text {th }}$ century. Their principal use was after ca. A.D. 1480 .

In addition to the Caddo settlement and use of the Saline Creek valley for many hundreds of years, the valley was also settled for a short time by the Cherokee Indians. In particular, Chief Bowles of the Cherokee was reported to have lived near the Neches Saline from 1837 to as late as October 1838 (Woldert 1923:186, 213). His residence was ca. 1.75 miles east of the saline. No archaeological remains of Cherokee Indian sites have as yet been found in the Saline Creek valley.

\section{Acknowledgments}

Patti Haskins facilitated access to the Caddo vessels from the Vanderpool site in the collections of the Gregg County Historical Museum. Jonathan Jarvis and Marybeth Tomka provided access to key site collections and records held by the Texas Archeological Research Laboratory at The University of Texas at Austin. Thanks also to Sandy Hannum and Lance Trask for preparing some of the figures in this article; Bo Nelson took the vessel photographs used herein. 


\section{References Cited}

Anderson, K. M.

1972 Prehistoric Settlement of the Upper Neches River. Bulletin of the Texas Archeological Society 43:121-197.

Anderson, K. M., K. Gilmore, O. F. McCormick III, and E. P. Morenon

1974 Archaeological Investigations at Lake Palestine, Texas. Contributions in Anthropology No. 11. Department of Anthropology, Southern Methodist University, Dallas.

Cole, N. M.

1975 Early Historic Caddoan Mortuary Practices in the Upper Neches Drainage, East Texas. Master's thesis, Department of Anthropology, The University of Texas at Austin.

Diggs Jr., G. M., B. L. Lipscomb, M. D. Reed and R. J. O’Kennon

2006 Illustrated Flora of East Texas, Volume One: Introduction, Pteridophytes, Gymnosperms, and Monocotyledons Sida, Botanical Miscellany, No. 26. Botanical Research Institute of Texas, Fort Worth.

Eubanks, P. N.

2014 The Timing and Distribution of Caddo Salt Production in Northwestern Louisiana. Southeastern Archaeology 33(1):108-122.

Gilmore, K.

1974 Appendix I-Analysis of Pipes. In Archaeological Investigations at Lake Palestine, Texas, by K. M. Anderson, K. Gilmore, O. F. McCormick III, and E. P. Morenon, pp. 192-197. Contributions in Anthropology No. 11. Department of Anthropology, Southern Methodist University, Dallas.

Hatcher, M. A.

1927 Description of the Tejas or Asinai Indians, 1691-1722, Part IV. Southwestern Historical Quarterly 31:150180.

Hoffman, M. P.

1967 Ceramic Pipe Style Chronology Along the Red River Drainage in Southwestern Arkansas. The Arkansas Archeologist 8(1):4-14.

Johnson, L., Jr.

1961 An Archeological Survey of Blackburn Crossing Reservoir on the Upper Neches River. Bulletin of the Texas Archeological Society 31:213-238.

Kenmotsu, N. A.

2005 Investigations at the Salt Well Slough Site (41RR204), a Salt Making Site in Red River County, Texas. Archeological Reports Series, No. 4. Texas Historical Commission, Austin.

Kleinschmidt, U. K. W.

1982 Review and Analysis of the A. C. Saunders Site, 41AN19, Anderson County, Texas. Master's thesis, Department of Anthropology, The University of Texas at Austin.

Marceaux, P. S.

2011 The Archaeology and Ethnohistory of the Hasinai Caddo: Material Culture and the Course of European Contact. Ph.D. dissertation, Department of Anthropology, The University of Texas at Austin.

Perttula, T. K.

2008 Caddo Agriculture on the Western Frontier of the Eastern Woodlands. Plains Anthropologist 53(205):77103.

2010 Archaeological Findings from an Historic Caddo Site (41AN184) in Anderson County, Texas. Journal of Northeast Texas Archaeology 33:53-61. 
2011 The Ceramic Artifacts from the Lang Pasture Site (41AN38) and the Place of the Site within an Upper Neches River Basin Caddo Ceramic Tradition. In Archeological Investigations at the Lang Pasture Site (41AN38) in the Upper Neches River Basin of East Texas, assembled and edited by T. K. Perttula, D. B. Kelley, and R. A. Ricklis pp. 145-320. Archeological Studies Program Report No. 129. Texas Department of Transportation, Environmental Affairs Division, Austin.

Perttula, T. K., with contributions by B. Nelson, L. Schniebs, and M. Walters

2016 The Caddo Archaeology of the San Pedro Creek Valley, Houston County, in East Texas. Journal of Northeast Texas Archaeology 68:1-72.

Perttula, T. K. and B. Nelson

2007 Archeological Survey Investigations and Test Excavations at 41 CE354 at the North and South Lake areas of the H.R.C. Cherokee Tree Farm, L. P. Project, Cherokee County, Texas. Report of Investigations No. 80. Archeological \& Environmental Consultants, LLC, Austin.

Perttula, T. K. and M. Walters

2016 Caddo Archaeology in the Caddo Creek Valley of the Upper Neches River Basin, Anderson and Henderson Counties, Texas. Special Publication No. 43. Friends of Northeast Texas Archaeology, Austin and Pittsburg.

Perttula, T. K., D. B. Kelley, and R. A. Ricklis (assemblers and editors)

2011 Archeological Investigations at the Lang Pasture Site (41AN38) in the Upper Neches River Basin of East Texas. Report No. 129. Texas Department of Transportation, Archeological Studies Program, Environmental Affairs Division, Austin.

Perttula, T. K., B. Nelson, and R. Z. Selden, Jr.

2013 Documentation of Cemeteries and Funerary Offerings from Sites in the Upper Neches River Basin, Anderson, Cherokee, and Smith Counties, Texas. Special Publication No. 26. Friends of Northeast Texas Archaeology, Pittsburg and Austin.

Perttula, T. K., M. Walters, S. Marceaux, and B. Nelson

2009 Caddo Pottery Vessels and Pipes from Sites in the Middle and Upper Sabine and Upper Neches River Basins, Smith and Wood Counties, Texas. Special Publication No. 7. Friends of Northeast Texas Archaeology, Pittsburg and Austin.

Reilly, F. K., III

2004 People of the Earth, People of the Sky: Visualizing the Sacred in Native American Art of the Mississippian Period. In Hero, Hawk, and Open Hand: American Indian Art of the Ancient Midwest and South, edited by R. F. Townsend, pp. 125-137. The Art Institute of Chicago in association with Yale University Press, New Haven.

Selden, R. Z., Jr., T. K. Perttula, and M. J. O’Brien

2014 Advances in Documentation, Digital Curation, Virtual Exhibition, and a Test of 3D Geometric Morphometrics: A Case Study of the Vanderpool Vessels from the Ancestral Caddo Territory. Advances in Archaeological Practice 2(2):64-79.

Skinner, S. A.

1971 Historical Archeology of the Neches Saline, Smith County, Texas. Archeological Report No. 21. Texas Historical Survey Committee, Austin.

Stokes, J. and J. Woodring

1981 Native-Made Artifacts of Clay. In Archeological Investigations at the George C. Davis Site, Cherokee County, Texas: Summers of 1979 and 1980, edited by D. A. Story, pp. 135-238. Occasional Paper No. 1. Texas Archeological Research Laboratory, The University of Texas at Austin. 
Suhm, D. A. and E. B. Jelks (editors)

1962 Handbook of Texas Archeology: Type Descriptions. Special Publication No. 1, Texas Archeological Society, and Bulletin No. 4, Texas Memorial Museum, Austin. Reprinted in 2009, Gustav's Library, Davenport, Iowa.

Walters, M.

2014 East Texas Archeological Society, Tyler, Texas, 1956-1959. Journal of Northeast Texas Archaeology 47:43-90.

Walters, M. and T. K. Perttula

2012 Certain Caddo Sites on Stone Chimney Creek, Cherokee County, Texas. Journal of Northeast Texas Archaeology 37:37-88.

Woldert, A.

1923 The Last of the Cherokees in Texas, and the Life and Death of Chief Bowles. Chronicles of Oklahoma 1(3):179-226. 